HAMILTON SOARES MOREIRA

ESTUDO DA INFLUÊNCIA DOS PARÂMETROS DE SOLDAGEM MIG E DA MORFOLOGIA DO CORDÃO NO COMPORTAMENTO À FADIGA DE JUNTAS SOLDADAS DE UM EIXO TRASEIRO VEICULAR 
HAMILTON SOARES MOREIRA

\section{ESTUDO DA INFLUÊNCIA DOS PARÂMETROS DE SOLDAGEM MIG E DA MORFOLOGIA DO CORDÃO NO COMPORTAMENTO À FADIGA DE JUNTAS SOLDADAS DE UM EIXO TRASEIRO VEICULAR}

Dissertação apresentada à Escola Politécnica da Universidade de São Paulo para a obtenção do Título de Mestre em Engenharia.

Área de Concentração:

Engenharia Metalúrgica e de Materiais

Orientador: Professor Dr. Cláudio G. Schön 
Este exemplar foi revisado e alterado em relação à versão original, sob responsabilidade única do autor e com a anuência de seu orientador.

São Paulo, 10 de Novembro de 2008.

Assinatura do autor

Assinatura do orientador

Moreira, Hamilton Soares

Estudo da influência dos parâmetros de soldagem MIG e da morfologia do cordão no comportamento à fadiga de juntas soldadas de um eixo traseiro veicular / H.S. Moreira. -- ed.rev. -São Paulo, 2008.

$84 \mathrm{p}$.

Dissertação (Mestrado) - Escola Politécnica da Universidade de São Paulo. Departamento de Engenharia Metalúrgica e de Materiais.

1. Soldagem MIG 2. Eixos 3. Fadiga dos materiais I. Universidade de São Paulo. Escola Politécnica. Departamento de Engenharia Metalúrgica e de Materiais II.t. 
Dedico esta dissertação:

A minha esposa Gisele Motta

pela força nos momentos difíceis,

A meus filhos Lucas e Giovanni pelo carinho, A meus pais Antonio Soares Moreira e Paulina da Luz Moreira pelos ensinamentos e incentivo constante. 


\section{AGRADECIMENTOS}

Bem sei que tudo podes, e nenhum dos teus planos pode ser frustrado.

Agradeço a DEUS por tudo.

Agradeço ao meu professor e orientador Cláudio G. Schön pela orientação segura, pelos conselhos e apoio nesta jornada.

Ao professor Sergio D. Brandi pelo incentivo durante a etapa de iniciação deste estudo.

Agradeço ao amigo Edson Eidi Yoshizawa pela compreensão e pelo incentivo durante o período em que trabalhamos juntos.

Aos colegas Danilo Carastan, Robson dos Santos e Francisco Cintra pelo conhecimento compartilhado.

Aos colegas Robert Frei e Márcio Godoy da Benteler Automotive pelo auxílio nos ensaios experimentais.

Enfim a todos que contribuíram direta ou indiretamente para a conclusão desta dissertação. 


\title{
SUMÁRIO
}

\author{
LISTA DE FIGURAS \\ LISTA DE TABELAS \\ RESUMO
}

ABSTRACT

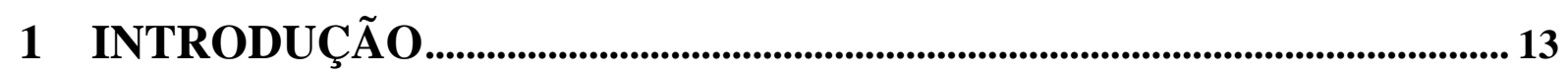

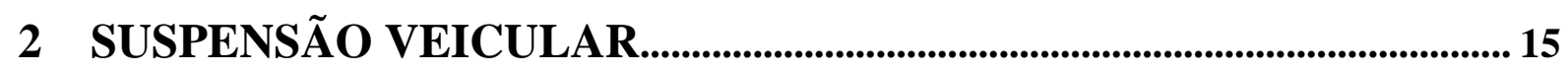

2.1 Características funcionais do sistema de suspensão .....................................15

$2.2 \mathrm{O}$ sistema de suspensão ...........................................................................17

2.3 Suspensão traseira interdependente ou semi-rígida......................................20

2.4 Carregamentos em serviço .......................................................................22

2.4.1 Carregamentos cíclicos.......................................................................................................... 24

2.4.2 Acúmulo de danos ..................................................................................................... 25

3 REVISÃO BIBLIOGRÁFICA ..................................................................... 26

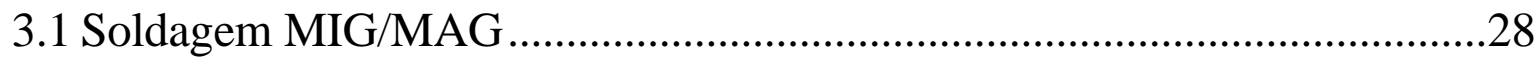

3.1.1 Síntese do Processo ........................................................................................................ 28

3.1.2 Parâmetros de interesse do processo de soldagem MIG/MAG............................ 29

3.1.3 Influência dos parâmetros de soldagem na geometria do cordão.........................36

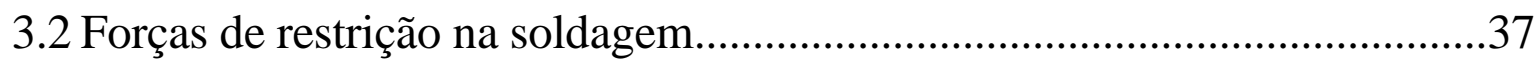

3.2.1 O fenômeno do "mismatching" nas juntas soldadas................................................. 39

3.2.2 Tensão residual da solda e seu efeito na vida à fadiga ............................................. 41

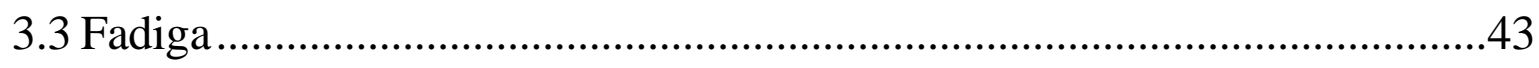

3.3.1 Comportamento da trinca de fadiga.............................................................................. 45

3.3.2 Fatores que afetam a vida à fadiga de juntas soldadas ............................................ 47

4 OBJETIVOS ……............................................................................................................53

5 MATERIAIS E MÉTODOS....................................................................... 54

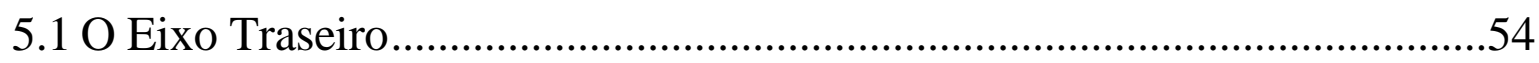

5.1.1 Características físico-geométricas do eixo ......................................................................54 
5.1.2 Características mecânicas e composição química dos componentes e metal de

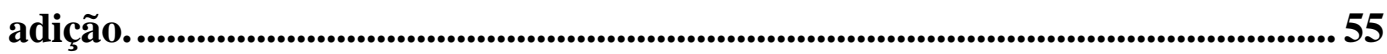

$5.2 \mathrm{O}$ processo de soldagem ..............................................................56

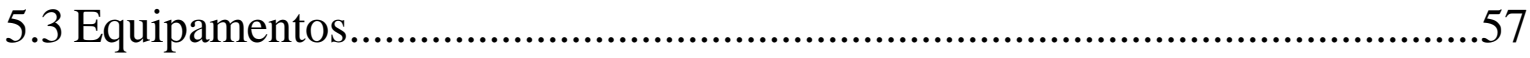

5.3.1 Dispositivo de Soldagem ............................................................................................................... 57

5.3.2 Dispositivo de testes ................................................................................................................................ 58

5.3.3 Equipamentos de análise do cordão ................................................................................ 59

5.4 Procedimento de teste ........................................................................61

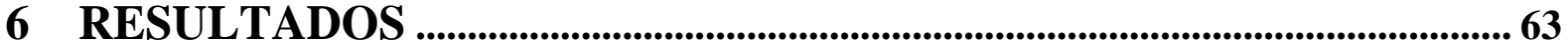

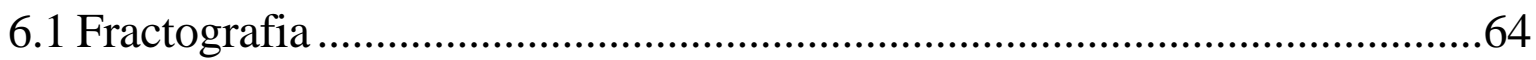

6.2 Análise metalográfica ......................................................................68

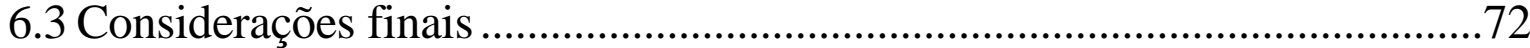

7 CONCLUS ÕES ..................................................................................................... 77

REFERÊNCIAS BIBLIOGRÁFICAS....................................................................... 79 


\section{LISTA DE FIGURAS}

Figura 1.1 - Conjunto eixo traseiro soldado

Figura 2.1 - Ângulo de convergência das rodas da suspensão dianteira de um veículo [1] 16

Figura 2.2 - Ângulo de cambagem das rodas da suspensão dianteira de um veículo [1]...... 16

Figura 2.3 - Esquema de suspensão de um (a) e três (b) graus de liberdade..... 17

Figura 2.4 - Tendência direcional do veículo em curvas [3]

Figura 2.5 - Ângulo de convergência da roda do eixo traseiro sob ação de força lateral (em curva) [1].. 22

Figura 2.6 - Carregamentos que são aplicados na roda com o veículo em operação.................................. 23

Figura 2.7 - Ciclos de tensão: (a) constante, (b) em bloco, (c) variável ...................................................... 24

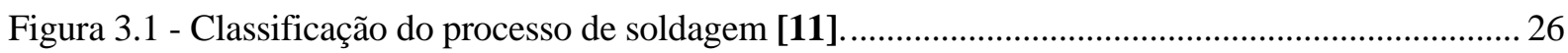

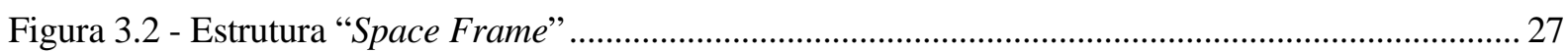

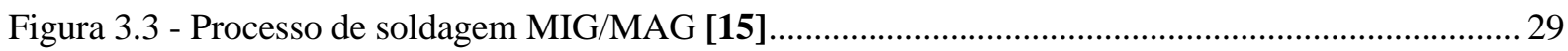

Figura 3.4 - Efeito da tensão de soldagem na penetração da solda [15].................................................... 30

Figura 3.5 - Diferentes tipos de modos de transferência metálica em MIG/MAG como classificado pelo

IIW; A - globular; B - globular repelida, C - gotícula projetada, D - com elongamento

("streaming"); E - goticular rotacional; F - goticular explosivo; G - curto-circuito [17].............. 31

Figura 3.6 - Efeito da corrente de soldagem na taxa de fusão para diferentes eletrodos [15] .................. 32

Figura 3.7 - Relação entre intensidade de corrente e a incidência de defeitos na geometria da solda ...... 33

Figura 3.8 - Relação entre tensão do arco e a incidência de defeitos na geometria da solda..................... 34

Figura 3.9 - Relação entre a velocidade de soldagem e a incidência de defeitos na geometria da solda . 35

Figura 3.10 - Seção transversal do cordão de solda e suas características principais [18] 36

Figura 3.11 - Distribuição da tensão residual (seção transversal) em uma solda de topo (a) aço médio carbono (b) liga de alumínio (c) aço estrutural de alta liga [14]

Figura 3.12 - Medida do deslocamento de abertura de trinca mostrando a ocorrência de plasticidade induzida pelo fechamento de trinca a uma tensão positiva de acordo com Elber [5]..

Figura 3.13 - Diferentes fases da vida em fadiga e fatores relevantes. Adaptado de Schijve [5]............. 44

Figura 3.14 - Tensão versus curva de deslocamento de abertura da trinca [51] ......................................... 46

Figura 3.15 - Características geométricas do cordão de solda de topo........................................................ 48

Figura 3.16 - Tensão residual longitudinal para diferentes temperaturas de pré-aquecimento [56].......... 49

Figura 3.17 - Características geométricas da junta "T” [57]....................................................................... 50

Figura 3.18 - Relação entre resistência à fadiga e profundidade de penetração da solda [57] ..................50

Figura 5.1 - Conjunto eixo traseiro soldado e seus componentes.................................................................5 54

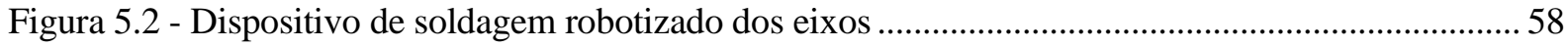

Figura 5.3 - Dispositivo para ensaio de torção do eixo - www.sincotec.de acessado em 26.07.07. ......... 59

Figura 5.4 - Indicação das posições de corte do eixo para análise do cordão ............................................. 60 
Figura 5.5 - Equipamento de medição do cordão de solda . 60

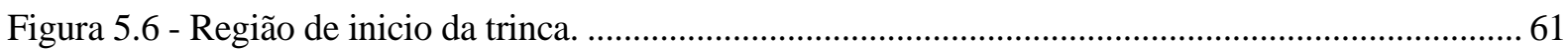

Figura 5.7 - Detalhe da região crítica de tensão revelado na análise de elementos finitos..........................62

Figura 6.1 - Efeito da alteração dos parâmetros de soldagem na fadiga das juntas soldadas ..................... 63

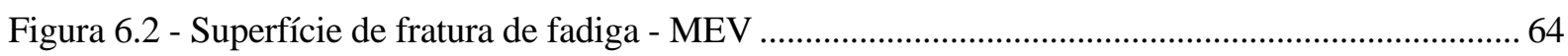

Figura 6.3 - Detalhe mostra a oxidação na superfície da fratura - MEV ................................................... 65

Figura 6.4 - Secções transversais do cordão de solda com falta de penetração. .......................................... 66

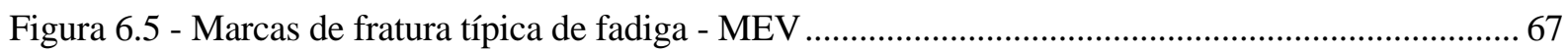

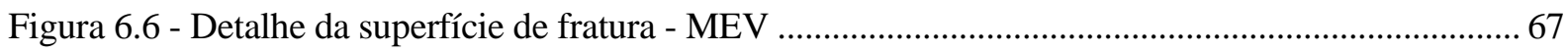

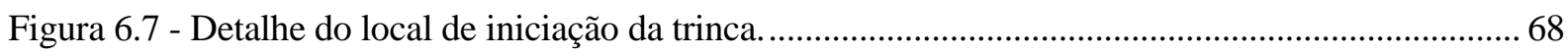

Figura 6.8 - Grão grosseiros de ferrita na escora. Ferrita acicular com traços de perlita na travessa "V".69

Figura 6.9 - Matriz de ferrita e traços de perlita na escora. Ferrita e traços de perlita de grão fino na

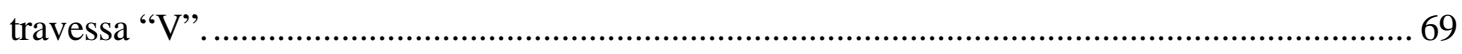

Figura 6.10 - Microestrutura de grãos colunares de ferrita acicular......................................................... 70

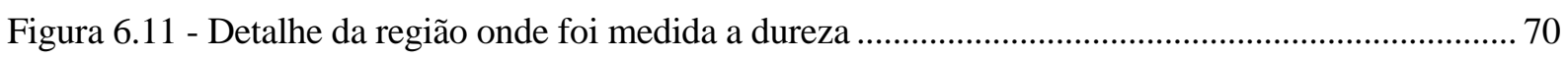

Figura 6.12 - Seções transversais da região onde foi medida a dureza ....................................................... 71

Figura 6.13 - Resumo dos resultados de medição da dureza Vickers ....................................................... 72

Figura 6.14 - Variação da penetração ao longo do cordão para cada versão de eixo .................................. 73

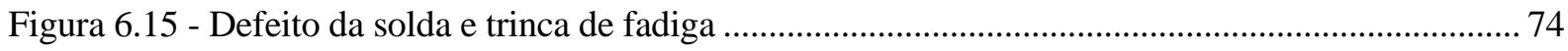

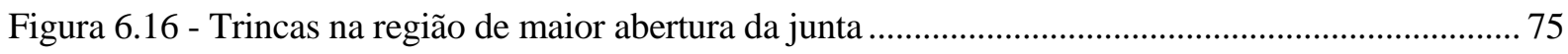

Figura 6.17 - Seções do cordão de solda pelo processo 9mm/seg (versão "A”) ........................................ 75

Figura 6.18 - Seções do cordão de solda pelo processo $15 \mathrm{~mm} / \mathrm{seg}$ (versão "B") ....................................... 76 


\section{LISTA DE TABELAS}

Tabela 5.1 - Valores permitidos para composição química dos componentes de aço (metal de base) e metal de adição. 56

Tabela 5.2 - Valores permitidos de resistência mecânica dos componentes e metal de adição .56

Tabela 5.3 - Variáveis adotadas para avaliação experimental . 57

Tabela 6.1 - Propriedades mecânicas do cordão e adjacências - medição através de HV10 72

Tabela 6.2 - Incidência de defeitos nos cordões de solda .73 


\section{RESUMO}

Atualmente a maioria dos veículos de passeio, pequenos e médios, são equipados com eixo traseiro do tipo interdependente. Seu baixo custo de fabricação e instalação fácil faz dele o preferido pela indústria automotiva. Normalmente, o eixo traseiro interdependente é um conjunto soldado e sua fabricação requer um controle do processo e qualidade das juntas soldadas de alto nível, devido a uma característica típica de projeto: eixos traseiros interdependentes possuem tensões críticas nos seus cordões de solda. Neste estudo, foi avaliado o quanto alterações nos parâmetros de soldagem afetam a geometria da solda e esta, por sua vez, compromete a vida à fadiga de um eixo interdependente. Através da variação dos parâmetros primários de soldagem (corrente, tensão e velocidade de soldagem), foi criado duas classes de eixos: classe "A" - 22V; 235A; 9mm/seg e classe "B" - 29V, 302A; 15mm/seg. Estes eixos foram submetidos a um ensaio de torção com carga em amplitude constante e seus desempenhos foram medidos através da curva de vida à fadiga. A variação dos parâmetros de soldagem afetou a geometria do cordão de solda, provocando nos eixos da classe "B" o surgimento de defeitos como baixa penetração da solda e mordedura. O resultado da análise metalográfica indica que estes defeitos influenciaram na resistência à fadiga dos eixos. A fractografia das fraturas confirmou que as falhas ocorreram por fadiga.

Palavras-chave: Engenharia. Soldagem. MIG. MAG. Eixo. Fadiga. 


\begin{abstract}
Nowadays most of the light, small and medium vehicles are equipped with a twist beam rear axle. Its low-cost production and easy assembly makes it the favorite axle type for the automotive industries and suspension developers. Usually the twist beam rear axle is a welded assembly and its production request a process control and high-level quality of the welded joint, due to a typical project characteristic: twist beam rear axle have critical tensions in their welds beads. It was evaluated in this study, how much the alterations in the welding parameters affects the weld bead geometry and this, for its time, affects the fatigue life of the twist beam rear axle. Through the variation of the welding primary parameters (welding current, arc voltage and welding speed), it was manufactured two classes of the axles: class "A" - 22V; 235A; $9 \mathrm{~mm} / \mathrm{seg}$ and class "B" - 29V, 302A; 15mm/seg. These axles were submitted the constant amplitude fatigue torsion testing and your performance were measured through the fatigue life curve. The variation of the welding parameters affected the weld bead geometry, inducing on the class "B" axle, the appearance of defects as low weld penetration and undercut. The metalography investigation indicates that these defects influenced in the fatigue life resistance. The fractures fractography confirmed that the flaws happened for fatigue.
\end{abstract}

Keywords: Engineering. Welding. MIG. MAG. Twist Beam. Axle. Fatigue. 


\section{INTRODUÇÃO}

Soldagem é uma tecnologia fundamental para fabricação de conjuntos metálicos estruturais, que em diversas indústrias, notavelmente na fabricação de automóveis, tem a vantagem de poder ser executada por robôs ou outros equipamentos automatizados.

A introdução de processos de soldagem automáticos trouxe grandes vantagens para a indústria automobilística em comparação com os processos manuais e semi-automáticos, devido à possibilidade de programação dos parâmetros de soldagem, garantindo a reprodutibilidade por exemplo do posicionamento do início e fim do cordão, tão importante para determinar a qualidade do cordão de solda e, conseqüentemente, do componente.

Com o passar dos anos, os processos de soldagem automáticos vêm passando por vários avanços tecnológicos, merecendo destaque soldagem a arco elétrico com utilização de gases inertes (MIG), gases ativos (MAG). Com o avanço da modernização e alta tecnologia, as indústrias, cada vez mais, buscam ganhar mercado com alta produtividade e redução de custos de produção, aliada a uma excelente qualidade do produto.

Apesar de muitas vantagens, a soldagem tem algumas desvantagens inerentes ao processo, como por exemplo: expansão e contração térmicas localizadas, transformações microestruturais, introdução de tensões residuais e distorções desenvolvidas pelo componente soldado em função do elevado aporte de calor introduzido durante o processo.

É fundamental para o sucesso de uma boa qualidade do cordão de solda MIG ou MAG, a correta seleção dos parâmetros de soldagem, tais como intensidade de corrente, tensão do arco, velocidade de soldagem, tipos de gases de proteção, entre outros.

Paralelamente a isto, estruturas soldadas são sujeitas ao carregamento dinâmico em serviço, tipicamente na forma de carregamentos aleatórios, como tubos, guindastes, navios, carroceria e componentes de veículos, aviões, pontes, estruturas marítimas e vasos de pressão, sendo portanto, afetados por fadiga.

Comportamento de fadiga destas estruturas soldadas é complexo por muitos fatores intrínsecos à natureza da junta soldada. Por exemplo defeitos como trincas, inclusão, porosidade, falta de penetração ou mordedura na margem da face do cordão de solda podem ser introduzidos em juntas soldadas, ocasionando na maioria das vezes concentração de tensão.

O objetivo do presente trabalho é investigar a influência de parâmetros, como intensidade de corrente, tensão do arco e velocidade de soldagem, do processo MIG, sobre a geometria do 
cordão de solda e por conseqüência investigar sua influência sobre o comportamento à fadiga de um eixo traseiro veicular representado na Figura 1.1.

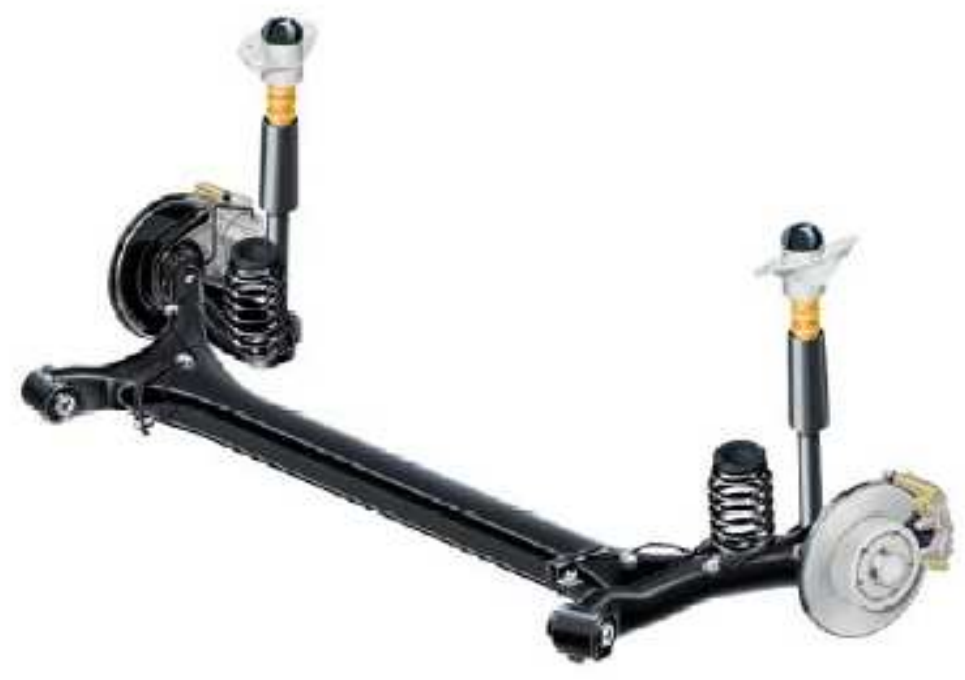

Figura 1.1 - Conjunto eixo traseiro soldado 


\section{SUSPENSÃO VEICULAR}

\subsection{Características funcionais do sistema de suspensão}

Um veículo em marcha sofre solicitações que sobrecarregam seus componentes estruturais e seus ocupantes, devido a irregularidades provenientes do piso (estrada).

Para limitar o efeito da irregularidade do piso é necessária a utilização de um "filtro" de interface entre o piso e a carroceria do automóvel. Este filtro é conhecido como suspensão e possui as seguintes funções:

- Garantir uma boa dirigibilidade do veículo;

- Garantir o conforto necessário de marcha;

- Atenuar o máximo possível às solicitações na estrutura do veículo.

Existem vários tipos de suspensão de automóvel, algumas com peculiaridades próprias em termos funcionais e construtivos, mas todas elas possuem componentes básicos, que são:

Mola - elemento elástico que permite manter a atitude do veículo (altura em relação ao piso) e o movimento vertical relativo entre a roda e carroceria.

Amortecedor - possui a função de amortecer as oscilações provenientes do piso e que são nocivas ao conforto de marcha do veículo.

Braços da suspensão - permitem toda a cinemática do sistema que é definida a partir dos respectivos movimentos e restrições que promovem as alterações de ângulos de convergência $(\delta)$ e cambagem $(\gamma)$ das rodas necessários para a perfeita marcha do veículo, Figura 2.1 e Figura 2.2 , respectivamente. 


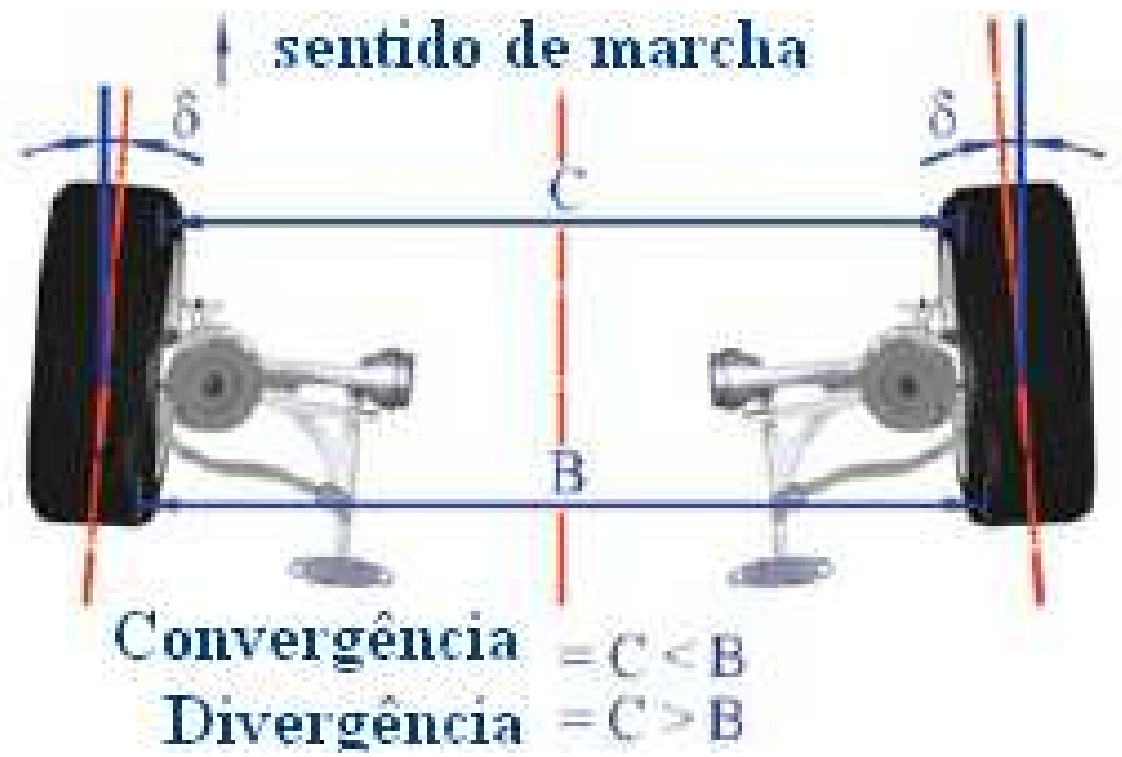

Figura 2.1 - Ângulo de convergência das rodas da suspensão dianteira de um veículo [1]

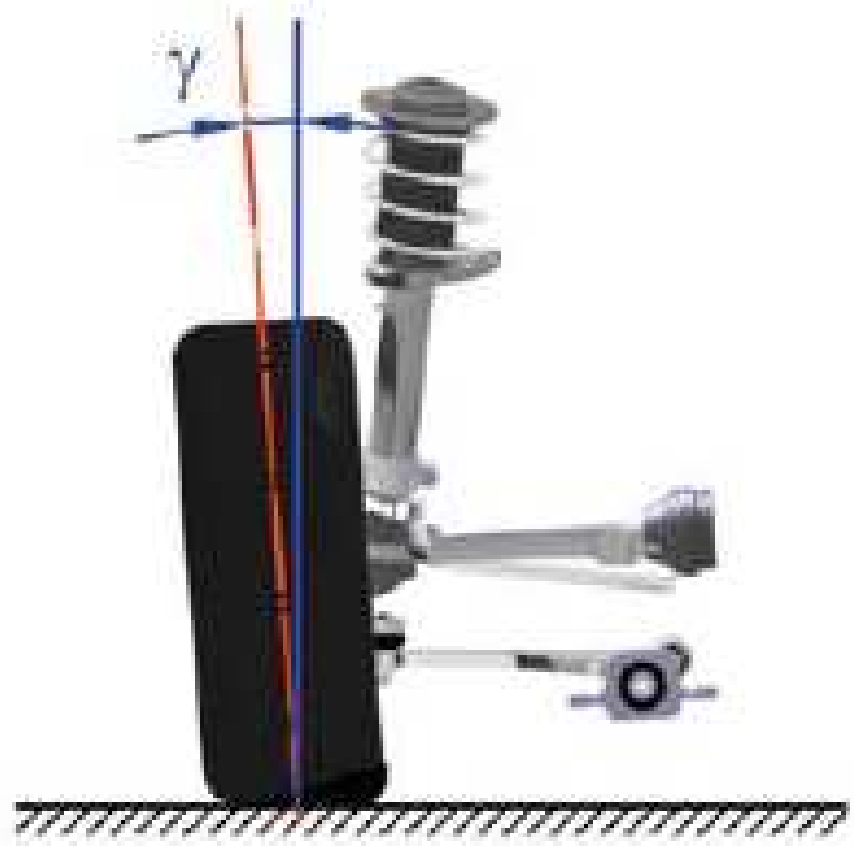

Figura 2.2 - Ângulo de cambagem das rodas da suspensão dianteira de um veículo [1] 


\subsection{O sistema de suspensão}

Como mencionado acima, suspensão é um sistema mecânico complexo, colocado entre a carroceria de um veículo e o solo e consiste de: mola, amortecedor, cinematismo (braço de suspensão, mancais de borracha, articulações, etc.) e roda (pneu e roda).

O sistema de suspensão deve ser tal que garanta o conforto e mantenha bom controle (dirigibilidade) para todo o tipo de estrada. Geralmente estes objetivos são conflitantes entre si, pois é difícil encontrar um bom compromisso para duas exigências tão diferentes; na realidade conforto significa sistema de suspensão bastante macio, pouco amortizado, com característica notável de absorção das irregularidades do piso, enquanto a propriedade de controle ou dirigibilidade requer sistema de suspensão potencialmente rígido e bem amortizado para garantir respostas rápidas ao esterçamento de direção e elevada estabilidade.

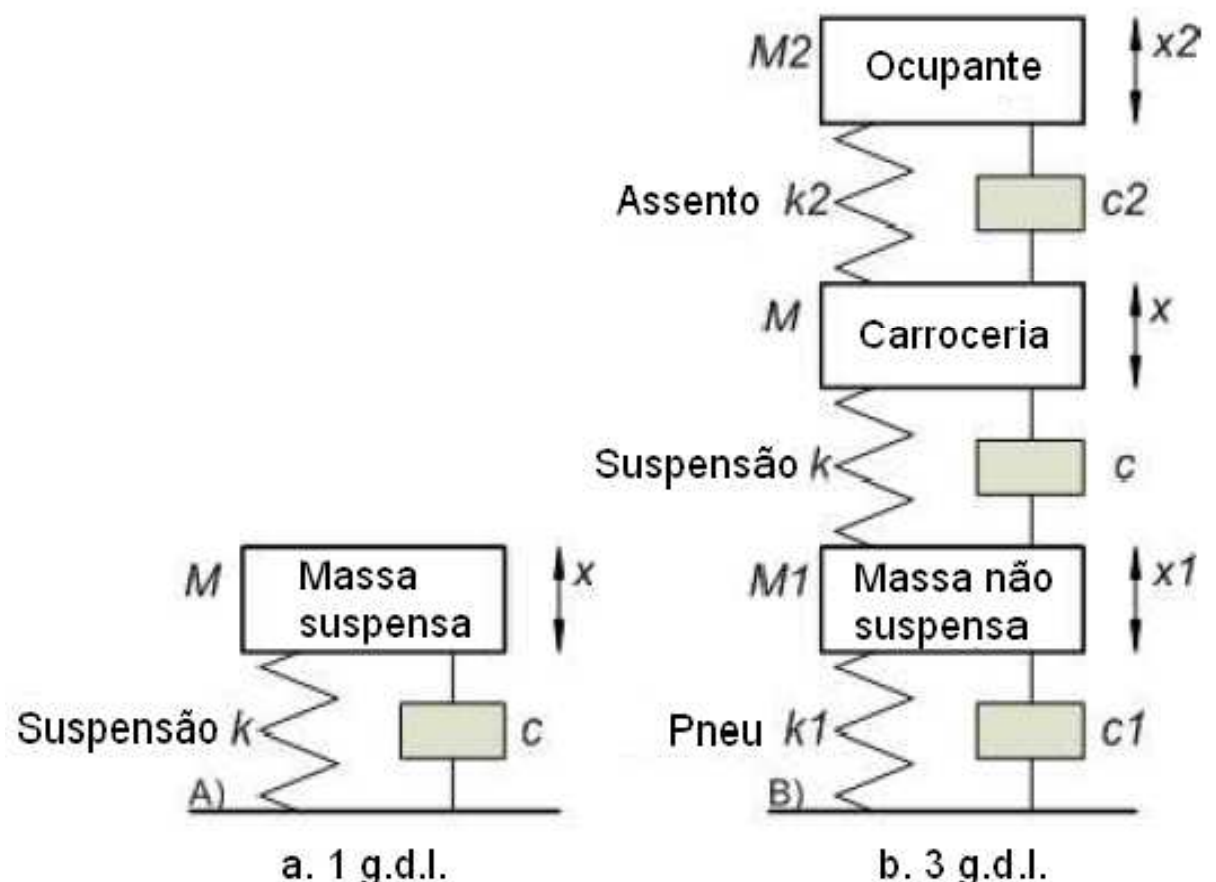

Figura 2.3 - Esquema de suspensão de um (a) e três (b) graus de liberdade

Faz-se necessário agora dar algumas definições fundamentais para detalhar o que são as características e as funções principais de uma suspensão, saber da complexidade da mola e amortecedores. 
Observando a Figura 2.3, considera-se o esquema de uma suspensão composto por uma massa M, neste caso como sendo a carroceria e seus ocupantes, um elemento elástico (mola da suspensão) e um amortecedor. Este é um modelo de um grau de liberdade, na qual a massa M pode mover-se em uma direção vertical neste caso específico.

Agora, em vez de considerar a carroceria e o ocupante (massa M), conectada ao piso por um elemento elasto-amortizante, o sistema será subdividido em mais massas, por exemplo, três (uma ligada à roda, uma à carroceria e sistemas mecânicos e uma para o ocupante) conectadas mutuamente por elementos elásticos e amortizantes, o modelo assume então três graus de liberdade. Neste caso as massas podem mover-se com movimentos verticais em sentidos diferentes uma das outras. Obviamente o sistema para três graus de liberdade é o que melhor representa o sistema, mas para simplificar faz-se referência ao caso simplificado do modelo para um grau de liberdade.

A equação que sustenta o movimento do sistema é:

$$
M a+c v+k x=0
$$

Onde:

$\mathrm{M}=$ massa suspensa em $\mathrm{kg}$;

$a=\frac{d^{2} x}{d t^{2}}=$ aceleração imposta à massa em $\mathrm{m} / \mathrm{seg}^{2}$;

$\mathrm{c}=$ coeficiente de amortecimento viscoso em $\mathrm{Nm} / \mathrm{seg}$;

$v=\frac{d x}{d t}=$ velocidade da massa $\mathrm{em} \mathrm{m} / \mathrm{seg}$

$\mathrm{k}=$ constante elástica da mola em N/mm;

$\mathrm{x}=$ deslocamento da massa $\mathrm{em} \mathrm{mm}$;

A equação (1b) é uma equação diferencial linear ordinária de grau dois. A solução geral é dada por:

$$
x(t)=C \exp [i f t]
$$

Sendo que f é a freqüência própria de oscilações, que é a frequiência assumida pelo sistema para o movimento natural, isto é, na ausência de forças externas de excitação. A constante imaginária 
C é determinada a partir das condições de contorno do problema, incluindo a perturbação que leva ao movimento, definido como um deslocamento diferente de zero no instante $\mathrm{t}=0$.

Substituindo-se (1b) em (1) observa-se que a freqüência própria é dada por:

$$
f=\frac{1}{2 \pi} \sqrt{\frac{k}{M}-\frac{c^{2}}{4 M^{2}}}
$$

A frequiência própria é a característica que melhor define um sistema de suspensão, pois possui todas as variáveis presentes nesta (massa, coeficiente de amortecimento, constante elástica). A fórmula supra, demonstra particularmente um indicativo da importância de todos os elementos do sistema de suspensão. Suponhamos, por exemplo, que o amortecedor seja removido ( $c=0$ ); neste caso f é real e possui duas soluções, uma com sinal invertido em relação à outra. $\mathrm{O}$ movimento de oscilação natural do novo sistema constituído exclusivamente da massa e mola corresponde a uma oscilação harmônica, e pode continuar indefinidamente com uma freqüência de oscilação igual a:

$$
f=\frac{1}{2 \pi} \sqrt{\frac{k}{M}}
$$

Esta consideração permite entender como a presença do amortecedor resulta essencialmente no amortecimento, por meio de seu atrito, dos movimentos oscilatórios da massa suspensa e não suspensa tendendo a diminuir, depois que a roda encontra um pequeno obstáculo, a amplitude.

Dito isto, se pode notar da expressão da freqüência $f$, com base no valor da raiz, que existem três tipos de movimento possíveis:

$\frac{k}{M}-\frac{c^{2}}{4 M^{2}}>0 \mathrm{O}$ sistema não oscila e tende a retroceder na posição de equilíbrio num tempo que aumenta na medida que o valor do coeficiente de amortecimento aumenta (igualdade de M e k).

$\frac{k}{M}-\frac{c^{2}}{4 M^{2}}<0$ O sistema é movido com um movimento oscilatório que depende das entidades $\mathrm{k}, \mathrm{c}, \mathrm{M}$. 
$\frac{k}{M}-\frac{c^{2}}{4 M^{2}}=0$ Representa a solução limite entre as duas acima descritas e é conhecido como amortecimento crítico.

\subsection{Suspensão traseira interdependente ou semi-rígida}

Desde da invenção do automóvel o problema de como interligar o automóvel aos diferentes tipos de piso (estrada) tem sido discutido e tal interesse foi responsável, portanto, para o desenvolvimento de sistemas de suspensão no curso da história do último século.

Embora haja diversos tipos de suspensão, neste trabalho, será descrita a suspensão traseira semirígida ou interdependente, suas vantagens e desvantagens e distribuição dos esforços onde, neste caso, o elemento principal é o eixo traseiro, objeto do estudo para análise de fadiga em juntas soldadas.

O eixo traseiro interdependente (twist-beam) foi desenvolvido na década de 70 e hoje é utilizado em veículos de passeio, pequenos e médios, com tração dianteira.

Ele consiste em dois braços longitudinais arrastados que são soldados a um elemento torcional transversal, fixado à carroceria por meio de mancais articuláveis, geralmente de borracha, e suportes metálicos. O elemento transversal absorve os momentos de forças verticais e laterais e, por ser deslocado da linha de centro das rodas, é menos rígido à torção e funciona como uma barra anti-rolagem do veículo [2]. O eixo possui numerosas vantagens, a saber:

Do ponto de vista de instalação:

- O eixo completo é facilmente montado e desmontado;

- Necessita de pouco espaço;

- A mola e amortecedor são facilmente ajustados;

- Não necessita de braços de controle ou barras de ligação;

- Possui poucos componentes para controlar.

Do ponto de vista da suspensão este sistema possui:

- Relação de esforços favorável entre roda e amortecedor/mola;

- Somente dois pontos de articulação;

- Baixa massa não suspensa; 
Do ponto de vista da cinemática este sistema se caracteriza por:

- Uma alteração desprezível na convergência e bitola do eixo durante o curso da suspensão, paralelo ou alternado;

- Pouca alteração de cambagem sobre carga lateral;

- Pouco subesterçamento do eixo dependente da carga da carroceria e;

- Uma disposição dos braços longitudinais que reduz o levantamento das rodas traseiras durante a frenagem.

A Figura 2.4 indica a reação do veículo em curvas quando se atinge o limite de aderência dos pneus. O projeto de uma suspensão veicular e sua característica geométrica define a tendência ao sobresterçamento ou subesterçamento em curvas.

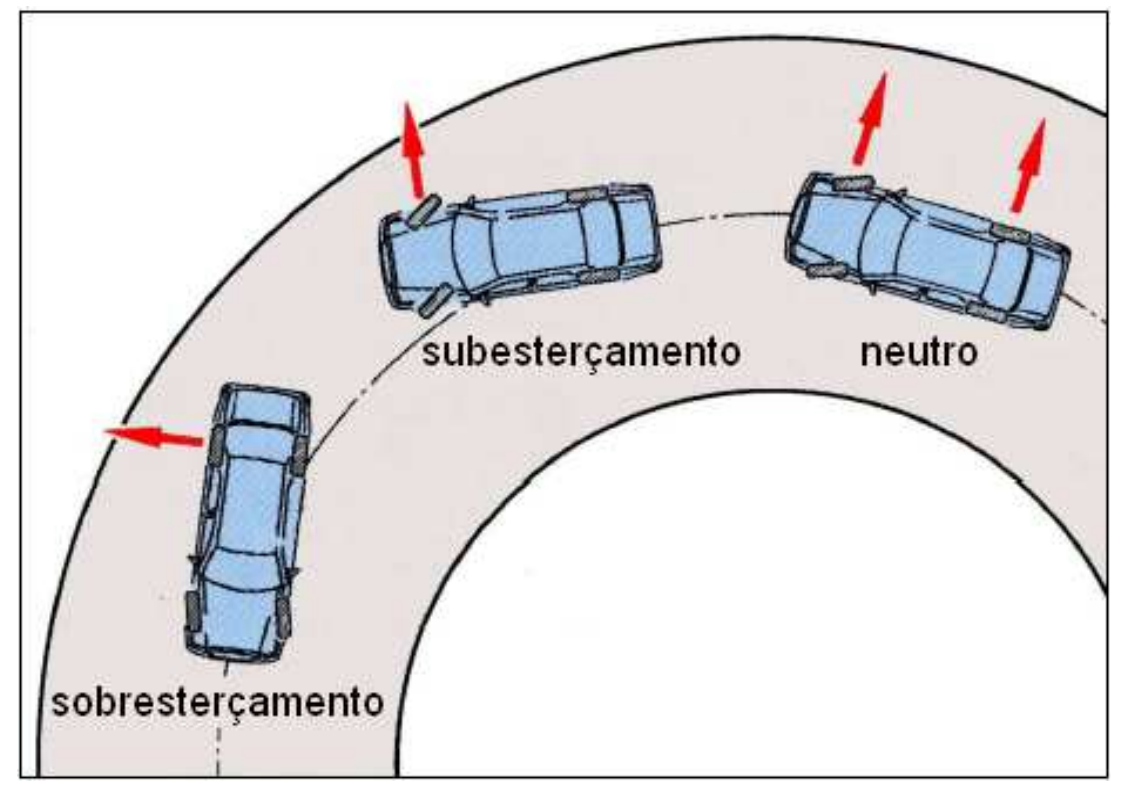

Figura 2.4 - Tendência direcional do veículo em curvas [3]

As desvantagens deste sistema são:

- Tendência ao sobresterçamento devido à deformação dos braços longitudinais sobre carga lateral. A Figura 2.5 indica a alteração da convergência da roda sob ação de força lateral (Fs);

- Surgimento de tensões de cisalhamento e de esforços de torção no elemento transversal;

- Elevada tensão nas soldas do eixo, que significa; 
○ que a permissibilidade de carregamento do eixo traseiro é limitada em termos de resistência;

- Cinemática e elasto-cinemática limitada;

- Determinação da posição do centro instantâneo por meio da cinemática e rigidez do elemento transversal;

- Interdependência das rodas;

- Dificuldade em isolar as vibrações e ruídos provenientes da pista;

- Necessidade de estabilizar a carroceria no mancal de articulação é complexo, devido à superposição de esforços que deve ser transmitido.

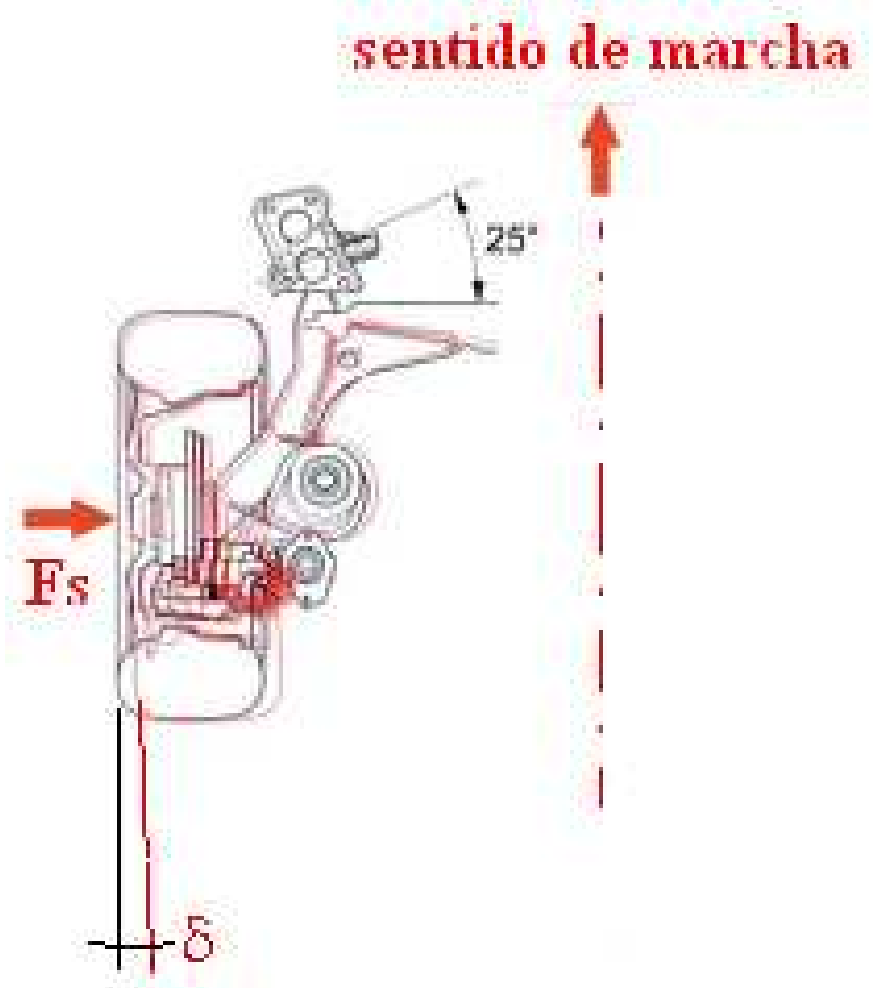

Figura 2.5 - Ângulo de convergência da roda do eixo traseiro sob ação de força lateral (em curva) [1]

\subsection{Carregamentos em serviço}

As suspensões ou eixos de um veículo estão sujeitos a carregamentos estáticos e dinâmicos. $\mathrm{O}$ carregamento estático varia entre o peso do veículo em ordem de marcha, ou seja, sem ocupante 
e pronto para rodar e a carga máxima, ou seja, com todos os ocupantes mais bagagem. A distribuição da massa total do veículo para o eixo dianteiro e traseiro, depende da posição do centro de gravidade ao longo do eixo $\mathrm{X}$ do veículo, definido como o eixo longitudinal.

O carregamento dinâmico provém das cargas de pista, dos efeitos da aceleração e da frenagem e das cargas laterais em curvas. A Figura 2.6 indica a reação do eixo traseiro aos esforços aplicados na roda.
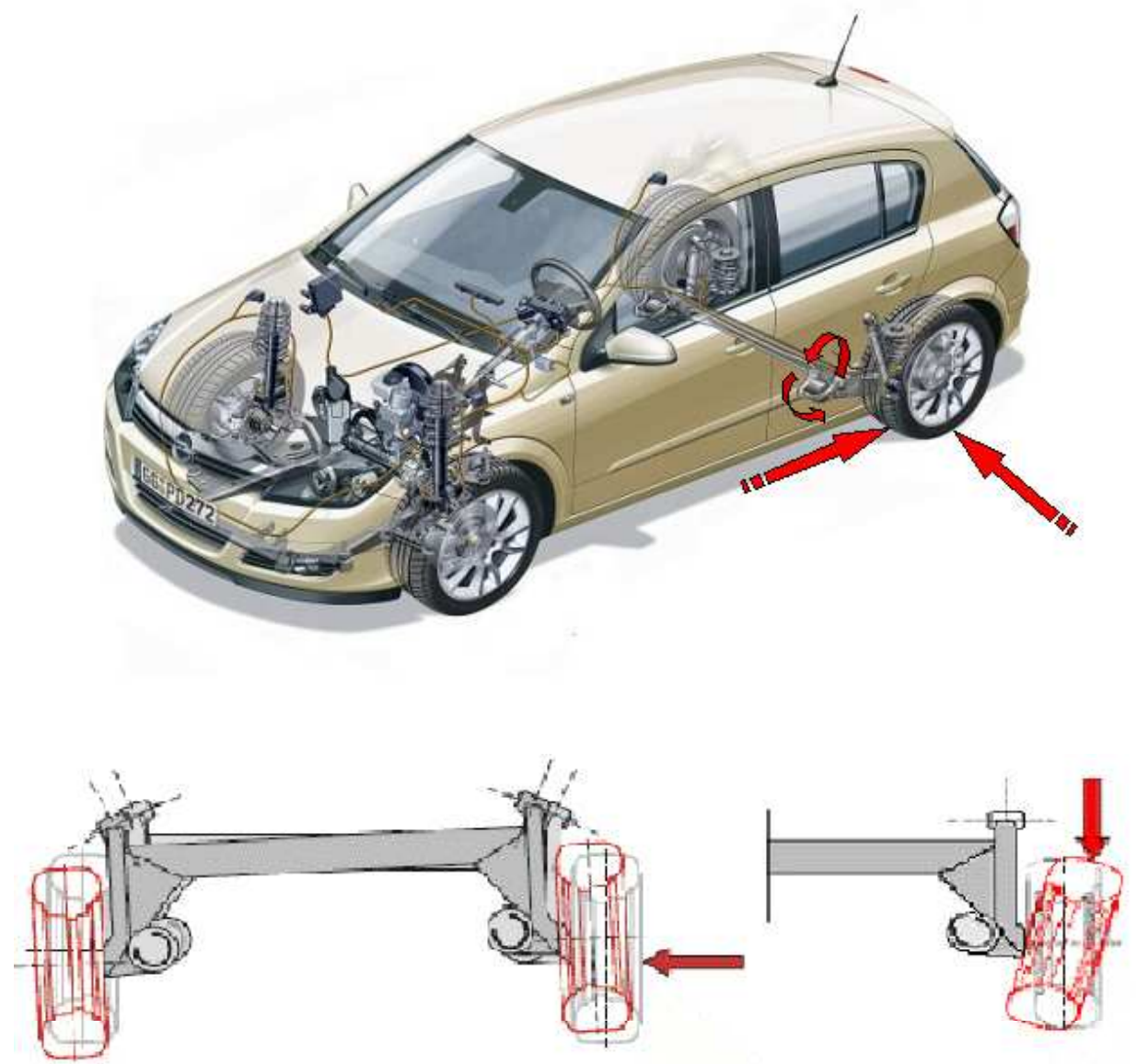

Figura 2.6 - Carregamentos que são aplicados na roda com o veículo em operação

Para análise de fadiga, o carregamento dinâmico é tratado em termos de tensão cíclica, podendo ser trabalhado em tensão-tempo ou deformação-tempo. Em geral definem-se três tipos de carregamento cíclico para análise. 


\subsubsection{Carregamentos cíclicos}

\subsubsection{Carregamento em amplitude constante (AC)}

É o carregamento em fadiga no qual a tensão ou deformação varia com o tempo em amplitudes iguais de máximo $\left(\boldsymbol{\sigma}_{\text {máx }}\right)$ e mínimo $\left(\boldsymbol{\sigma}_{\min }\right)$. São classificados também do ponto de vista de simetria de tensão, onde em amplitude simetricamente distribuída no tempo denomina-se ciclo reverso de tensões e no caso de amplitudes assimétricas denomina-se ciclo repetido [4].

\subsubsection{Carregamento em blocos}

Neste caso a tensão aplicada varia em intervalos em bloco do tempo, ou seja, a amplitude de tensão é constante durante um intervalo de tempo e logo em seguida a amplitude de tensão se altera e se mantém por um tempo e assim consecutivamente. Este também pode ser considerado como a "soma" de vários ciclos de amplitude constante de diferentes níveis de tensão.

\subsubsection{Carregamento em amplitude variável (AV)}

Este é o caso clássico de carregamento de um automóvel em marcha, ou seja, as irregularidades do piso são transferidas ao veículo de maneira aleatória, variando com o tempo e condições de carga do veículo.
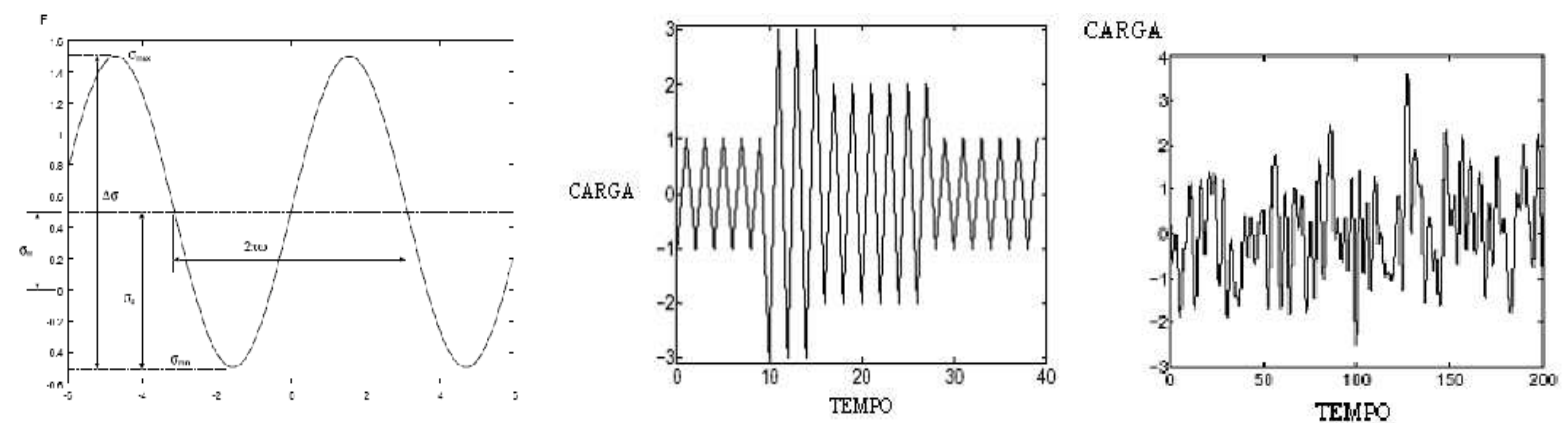

Figura 2.7 - Ciclos de tensão: (a) constante, (b) em bloco, (c) variável 


\subsubsection{Acúmulo de danos}

Para avaliação do desempenho de um veículo ou de seus componentes, são utilizados diversos métodos teóricos e experimentais. No caso do eixo traseiro os métodos teóricos mais comuns, para avaliação de sua integridade estrutural e comportamento dinâmico no veículo são: análise estrutural por elementos finitos, simulação dinâmica do veículo, análise de multi-corpos (corpos rígidos e flexíveis), análise da elasto-cinemática, etc.

Os métodos experimentais são: durabilidade veicular, análise funcional, avaliação dinâmica conforto e dirigibilidade (Ride e Handling), instrumentação e aquisição de dados, ensaios em banco de provas, ensaios laboratoriais, etc.

Para reproduzir nos bancos de prova as condições de carregamento do veículo em operação é necessário utilização de métodos que permitam transferir de maneira segura e eficaz as condições de pista. Ainda que a repetibilidade dos resultados sejam questionados [5][6][7], para encurtar tempo de desenvolvimento e reduzir custos, os ensaios em banco de provas para fadiga de componentes são os mais utilizados para validação de projetos.

Para que o ensaio em banco de provas represente fielmente as condições de rodagem de um componente, é preciso colher os sinais provenientes de um determinado piso, geralmente de uma rota conhecida. Estes sinais denominados "espectro de carregamento cíclico" são trabalhados, a fim de determinar o ciclo de carregamento equivalente para análise de acúmulo de dano e vida útil do componente.

Os métodos mais comuns para tratamento de sinais e análise de acúmulo de dano para previsão de vida em fadiga são: método "Rainflow" (RFC), regra de Pålmgren-Miner, método SWT (Smith-Watson-Topper) [8][9]. 


\section{REVISÃO BIBLIOGRÁFICA}

Segundo Wainer "Soldagem é a técnica de unir duas ou mais partes assegurando entre elas a continuidade e as características mecânicas e químicas do material" [10].

Os processos de soldagem podem ser classificados a partir da natureza da união, representados pela Figura $3.1[\mathbf{1 1}]$.

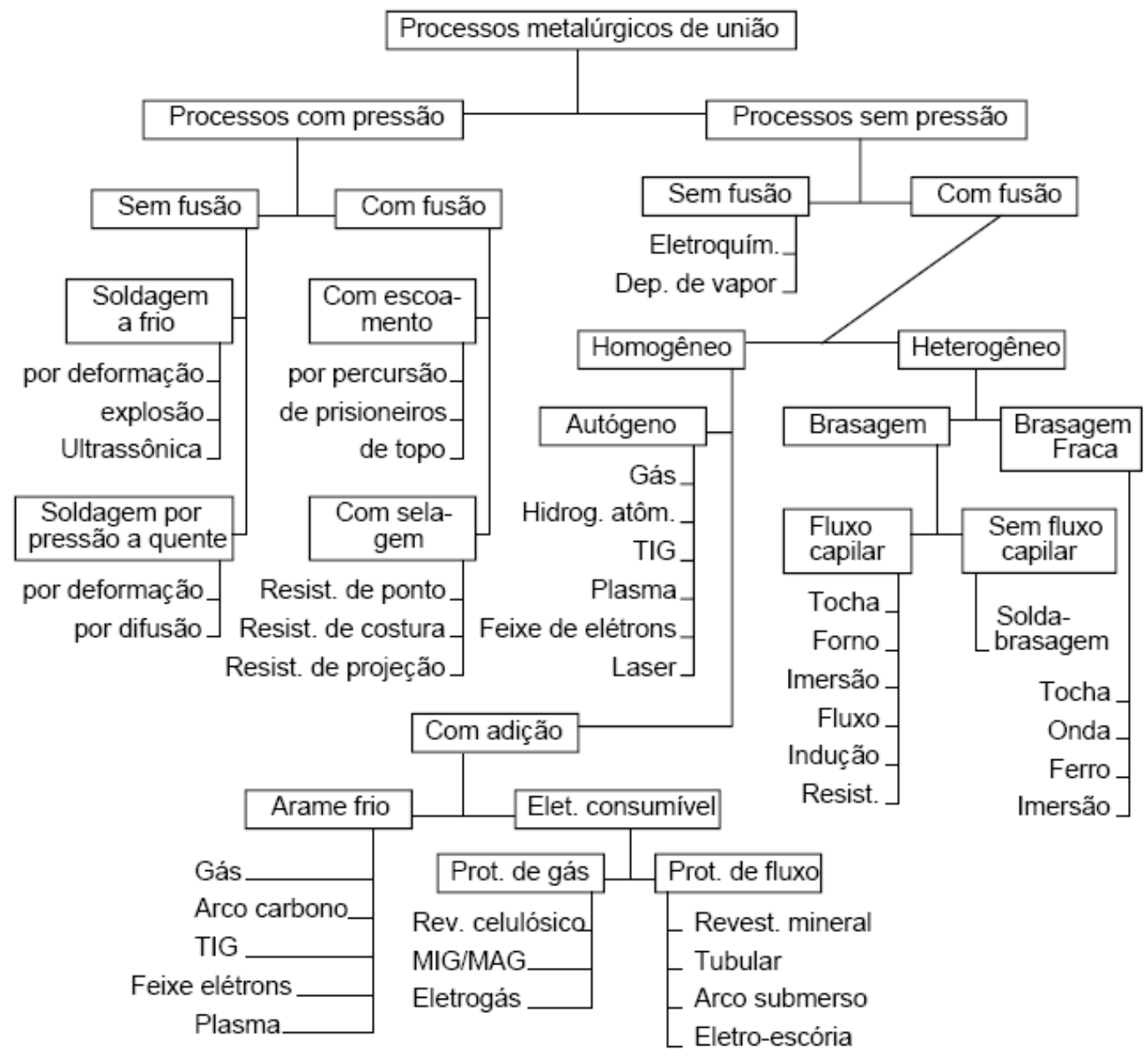

Figura 3.1 - Classificação do processo de soldagem [11].

A descoberta do arco elétrico em 1801 por Sir Humphrey Davy abriu um campo de desenvolvimento, o processo de soldagem elétrica, que evolui ao longo das décadas até os dias de hoje. Desde do estudo da soldagem por resistência elétrica de Thomson em 1877 e dos estudos de soldagem por arco de N. Bernardo e S. Olszewski em 1885, passando pela utilização 
do gás inerte como proteção do arco elétrico por H. M. Hobart e P. K. Denver em 1929, que o processo de soldagem não pára de evoluir. De acordo com Wainer et al., o processo de soldagem teve seu grande impulso na II Guerra Mundial, devido à fabricação de navios e aviões soldados [12].

Atualmente a soldagem é um dos processos mais utilizados na união entre partes metálicas, e vem sofrendo avanços tecnológicos, especialmente nos processos semi-automáticos e automáticos, devido principalmente a competitividade entre as indústrias que tem como principal matéria prima o aço.

Os processos de soldagem MIG/MAG são os principais meios de junção de componentes de aço em chassis e estruturas de automóvel. É também uma tendência na construção de veículos com estruturas tubulares denominado "space frame"1 Figura 3.2. Segundo Dong et al. [13] o principal benefício no projeto de soldagem MIG/MAG é a habilidade de unir as partes com somente um acesso lateral e a redução ou eliminação de flanges de união.

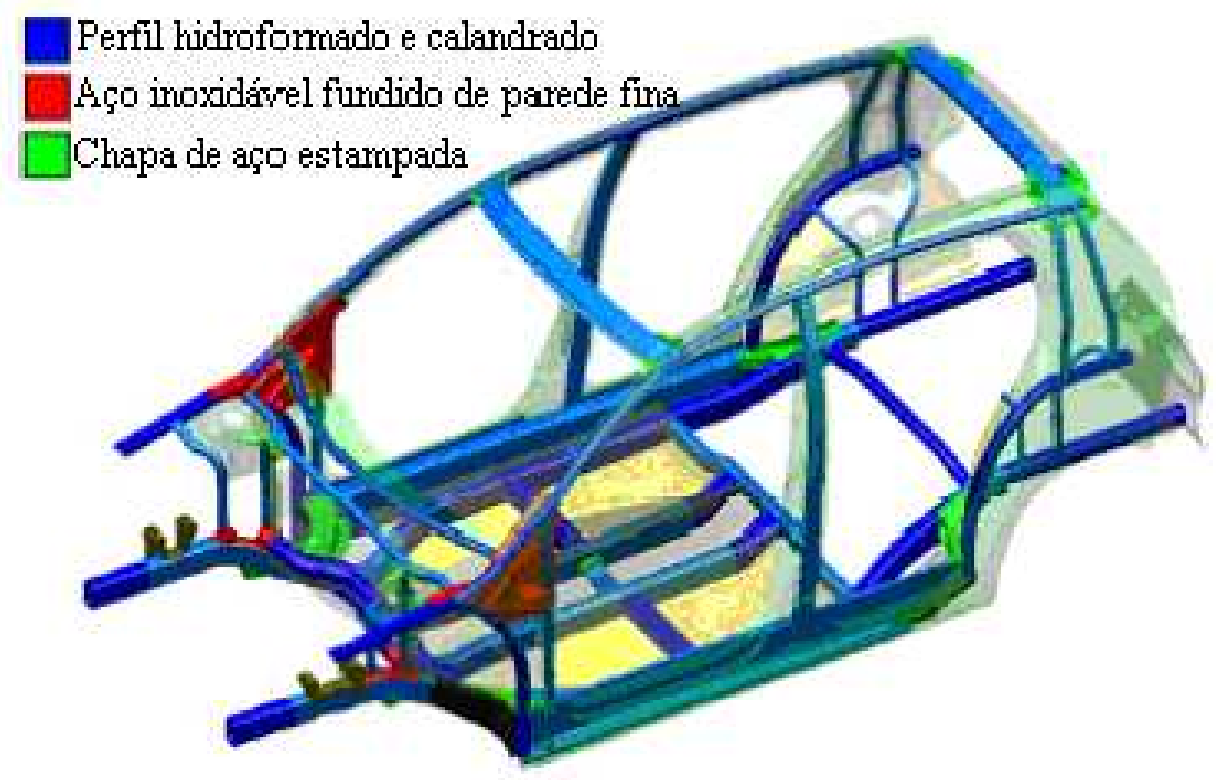

Figura 3.2 - Estrutura "Space Frame"

\footnotetext{
${ }^{1}$ Space Frame: conceito de estrutura tubular (ou perfil) metálico, tipo "gaiola", utilizada no desenvolvimento de veículos leves. Partes móveis da carroceria e chapas externas, metálicas ou poliméricas, são aplicadas à estrutura, por meio de adesivos ou soldagem, formando a carroceria completa.
} 
No entanto, a qualidade do cordão de solda obtido pelos processos MIG/MAG é influenciada por alguns parâmetros do processo, portanto, é preciso conhecê-los para selecionar o procedimento adequado a cada projeto de soldagem.

\subsection{Soldagem MIG/MAG}

\subsubsection{Síntese do Processo}

A Figura 3.3 mostra o processo MIG/MAG na qual uma provisão constante de elétrodo consumível (arame) é mantida através do centro do bocal de solda. Quando o elétrodo é aproximado da peça, um arco é produzido, o qual faz a ponta do eletrodo fundir e unir os lados da cavidade em $\mathrm{V}$ entre as duas chapas. Uma provisão constante do gás de proteção, por exemplo, $98 \%$ argônio e $2 \%$ oxigênio, também é mantida pelo bocal circular ao redor do arame, dentro do bocal, protegendo a soldagem de contaminação atmosférica.

Referente ao modelamento do processo, os seguintes fatores podem ser observados [14]:

- Parte do calor fornecido pelo arco é consumido para fundir o arame de solda continuamente;

- Parte do calor é perdido para o ambiente antes que seja recebido pelas chapas;

- O calor do arco e o metal fundido geram um fluxo de calor em todas as três dimensões na peça. Por conseguinte, mudanças metalúrgicas complexas são causadas dentro da zona fundida ou poça de fusão, devido ao severo ciclo térmico que sofre o metal. Adjacente a poça de fusão, o metal é aquecido abaixo da sua temperatura de fusão que causa mudanças significantes na micro-estrutura. Esta região é chamada zona afetada pelo calor (ZAC);

- No processo de transferência o calor é perdido a partir das superfícies por condução e radiação;

- O fluxo dos gases de proteção aumenta a perda por convecção do calor de uma parte da superfície. 


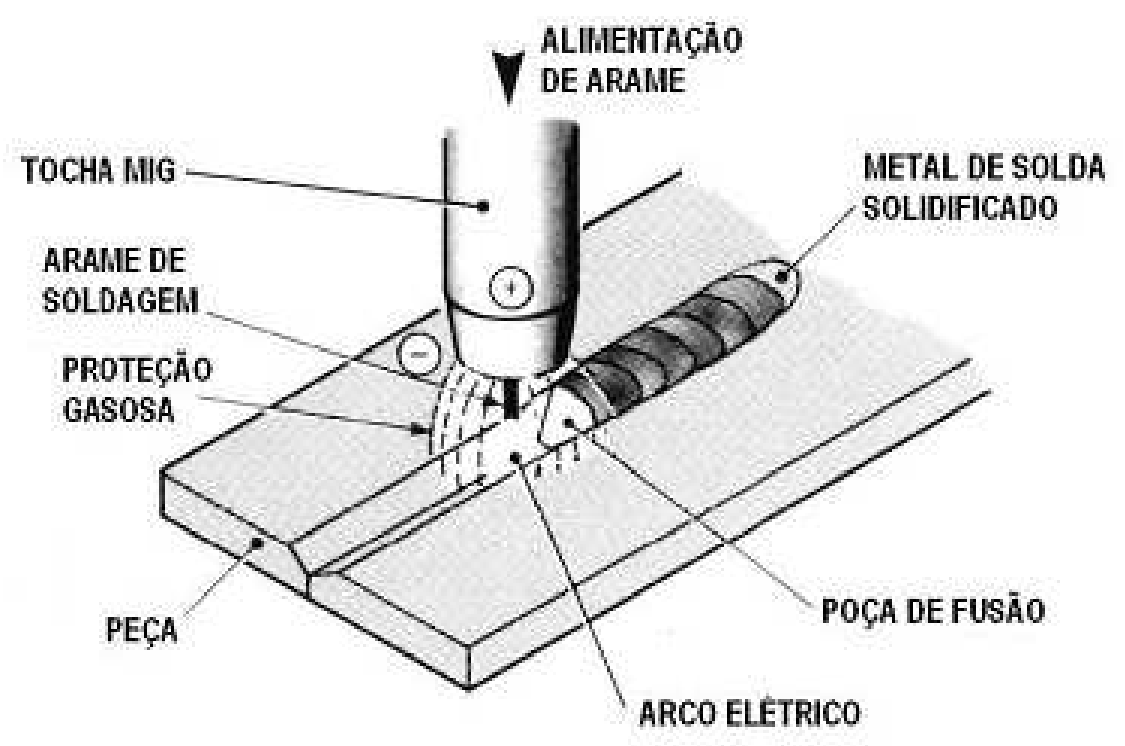

Figura 3.3 - Processo de soldagem MIG/MAG [15]

\subsubsection{Parâmetros de interesse do processo de soldagem MIG/MAG}

Os processos MIG/MAG utilizam fonte de corrente contínua e polaridade inversa com eletrodo positivo a fim de possibilitar melhor penetração e estabilidade do arco. Quando não é necessária grande penetração, é possível usar polaridade direta, o que aumenta a velocidade de deposição.

O controle da taxa de fusão do eletrodo é influenciado pela intensidade de corrente do arco que é determinada a partir da espessura das peças a serem soldadas, do diâmetro do eletrodo e das características do cordão [15].

Além do ajuste da corrente é também necessário escolher outros parâmetros da soldagem para controlar o processo a fim de se obter os resultados esperados. Estes parâmetros são tensão e o comprimento do arco, a velocidade de alimentação do eletrodo, comprimento livre do eletrodo (stick-out), a inclinação da pistola, o fluxo e tipo de gás. A velocidade de soldagem, a posição de soldagem e o diâmetro do eletrodo também influenciam consideravelmente na geometria do cordão de solda.

Segundo Jones (1978) apud Modenesi, pode-se dividir as variáveis de soldagem do processo a arco em quatro grupos básicos [16]:

- Variáveis pré-determinadas: tipo e espessura do metal de base; propriedades requeridas para o metal de solda; 
- Variáveis de fundo: processo de soldagem; tipo de equipamento; projeto da junta; técnica de soldagem; tipo e diâmetro de eletrodo, fluxo, gás, etc;

- Variáveis secundárias: comprimento do eletrodo e posicionamento da pistola em relação à peça;

- Variáveis primárias: corrente (tipo e intensidade); tensão e velocidade de soldagem.

\subsubsection{Tensão do Arco}

Tensão do arco, juntamente com o comprimento do arco, são dois parâmetros importantes na determinação das características do cordão, um está muito relacionado ao outro, pois a tensão do arco depende do comprimento do arco, do tipo e do diâmetro do eletrodo, do gás de proteção, influenciando assim o modo de transferência. Em um processo onde estes parâmetros são constantes, um aumento de tensão do arco gera um aumento da largura e uma diminuição da altura (ou reforço) do cordão de solda, além da redução da penetração, conforme mostrado na Figura 3.4.
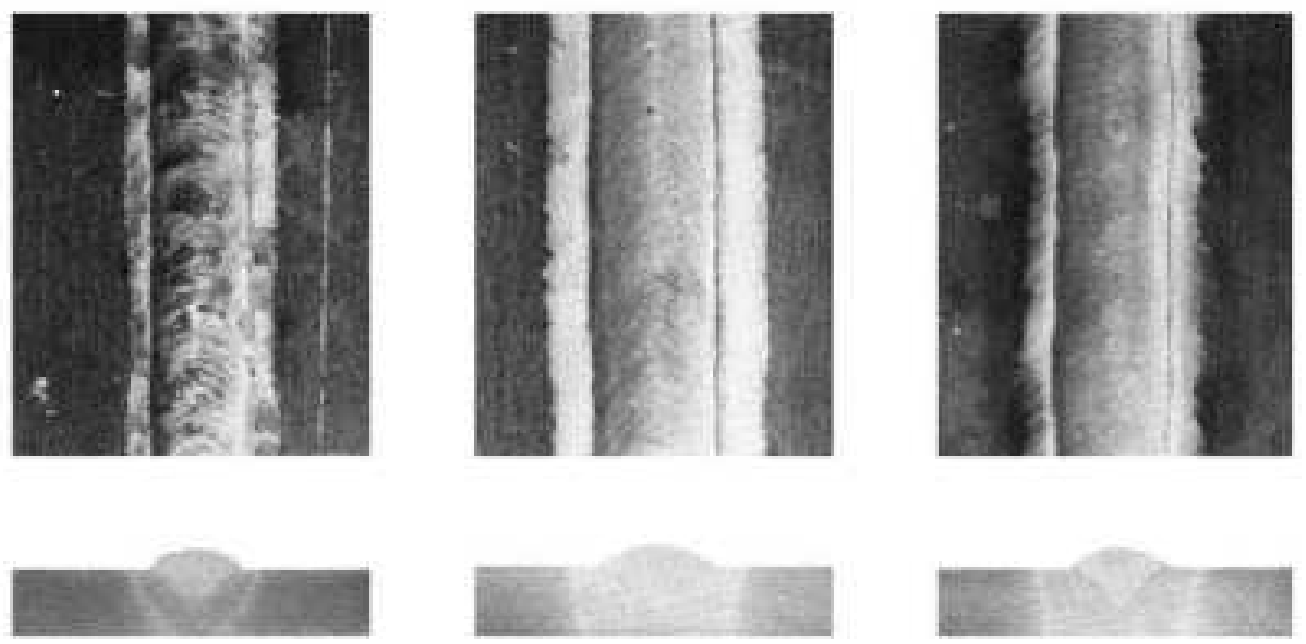

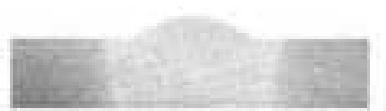

$24 \mathrm{~V}$

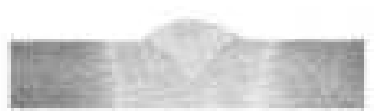

$27 \mathrm{~V}$

Figura 3.4 - Efeito da tensão de soldagem na penetração da solda [15].

Tensões elevadas do arco provocam excesso de respingos de solda e mordeduras e tensões baixas implicam em falta de fusão e cordões muito convexos [15]. 
A variação na tensão do arco não afeta somente as características geométricas do cordão de solda, mas também a sua microestrutura e conseqüentemente o sucesso ou fracasso da operação de soldagem pela quantidade de metal transferido. Quando a tensão do arco é muito baixa a transferência de metal é feita tanto por curto circuito (com baixa velocidade de alimentação) ou por transferência globular (alta velocidade de alimentação). O modo de transferência de metal de uma dada condição de soldagem depende também da intensidade da corrente elétrica do arco, composição química do metal de adição, tipo de gás de proteção, diâmetro e comprimento do eletrodo, etc [16]. Os modelos reconhecidos de transferência metálica estão descritos na Figura 3.5.

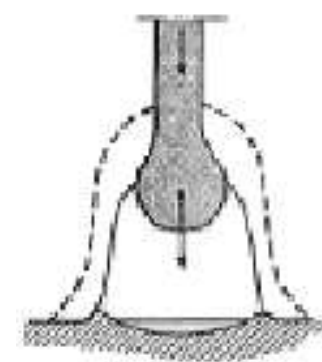

A
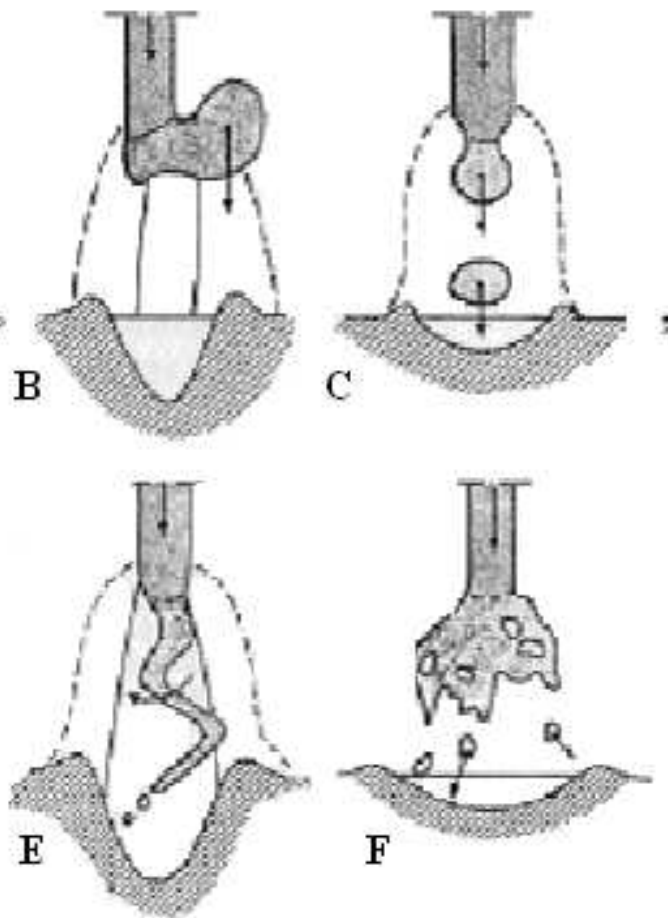

Figura 3.5 - Diferentes tipos de modos de transferência metálica em MIG/MAG como classificado pelo IIW; A - globular; B - globular repelida, C - gotícula projetada, D - com elongamento ("streaming"); E - goticular rotacional; F - goticular explosivo; $\mathrm{G}$ - curto-circuito [17].

\subsubsection{Corrente de Soldagem}

A corrente de soldagem é a corrente de saída da fonte quando a solda está sendo realizada. Se forem mantidas constantes todas as demais variáveis de soldagem, um aumento na corrente de soldagem, irá causar aumento na taxa de deposição e conseqüentemente aumento na profundidade e largura do cordão de solda [16]. 
No processo MIG/MAG a corrente de soldagem está diretamente relacionada à velocidade de alimentação do arame (desde que a extensão do eletrodo seja constante). Quando a velocidade de alimentação do arame é alterada, a corrente de soldagem varia no mesmo sentido. Em outras palavras, um aumento na velocidade de alimentação do arame causará um aumento da corrente de soldagem ou vice-versa. A Figura 3.6 mostra a relação típica entre a taxa de deposição do arame e a corrente de soldagem para diversos diâmetros do arame tipo ER70S3.

A Figura 3.6 mostra também que a relação é linear para baixas velocidades de alimentação, entretanto, à medida que a velocidade aumenta, particularmente quando o diâmetro do eletrodo é pequeno, a curva da taxa de deposição torna-se não linear. Isto é normalmente atribuído ao aumento da resistência térmica que aumenta por si só com o aumento da velocidade de alimentação. Para uma mesma velocidade de alimentação, o aumento no diâmetro do eletrodo demandaria um aumento na corrente. Novamente, o aumento na corrente, mantendo-se os outros parâmetros constantes, resulta em uma maior profundidade de penetração da solda, aumentando, também, a taxa de deposição de material e o tamanho do cordão de solda em sua seção transversal [15].

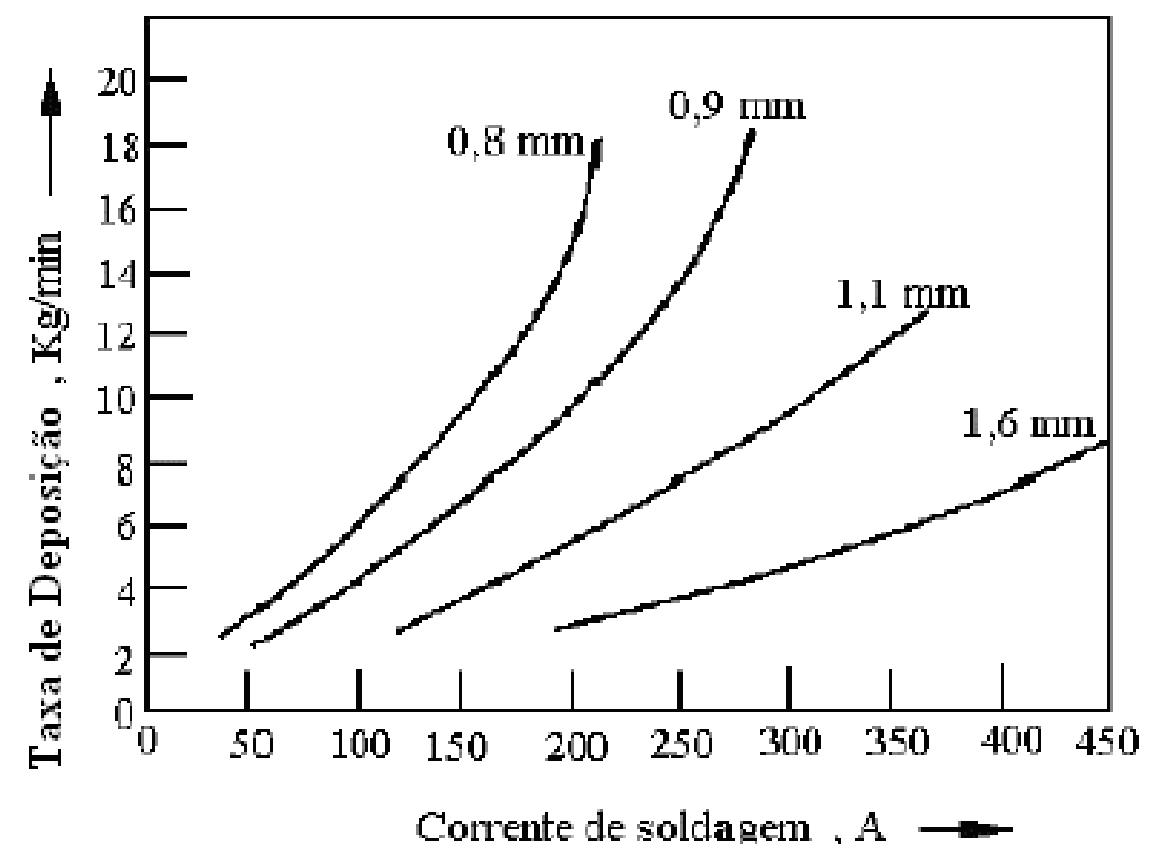

Figura 3.6 - Efeito da corrente de soldagem na taxa de fusão para diferentes eletrodos [15]. 


\subsubsection{Velocidade de Soldagem}

A velocidade de soldagem é a velocidade de deslocamento do arco elétrico ao longo do comprimento da junta. A penetração da solda é maior para velocidades menores de avanço da pistola e diminui com o aumento da velocidade, assim como a largura do cordão e a altura do reforço. A redução da largura e penetração do cordão com a velocidade de soldagem estão associadas à diminuição da quantidade de energia fornecida por unidade de comprimento da junta. A influência no reforço do cordão está associada à redução da quantidade de material de adição que é fornecido à solda, com o aumento da velocidade de soldagem [16].

Velocidade de soldagem muito alta pode acarretar descontinuidade do cordão pela falta de fusão do material.

A Figura 3.7 à 3.9, ilustram, esquematicamente e qualitativamente, a influência dos parâmetros primários de soldagem na geometria do cordão de solda. As características geométricas principais do cordão de solda (penetração, largura e altura), estão mostradas na Figura 3.10.

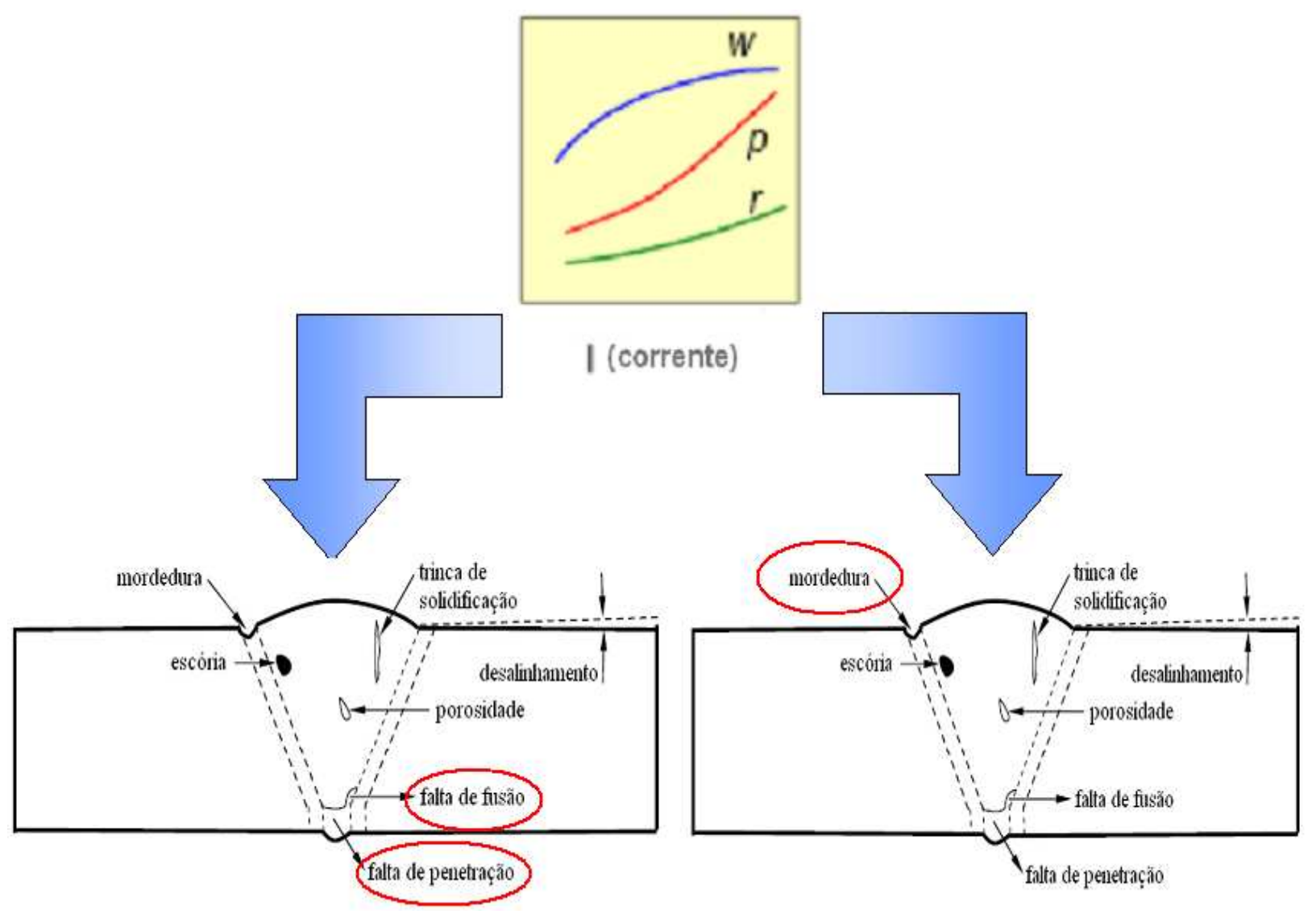

Figura 3.7 - Relação entre intensidade de corrente e a incidência de defeitos na geometria da solda 


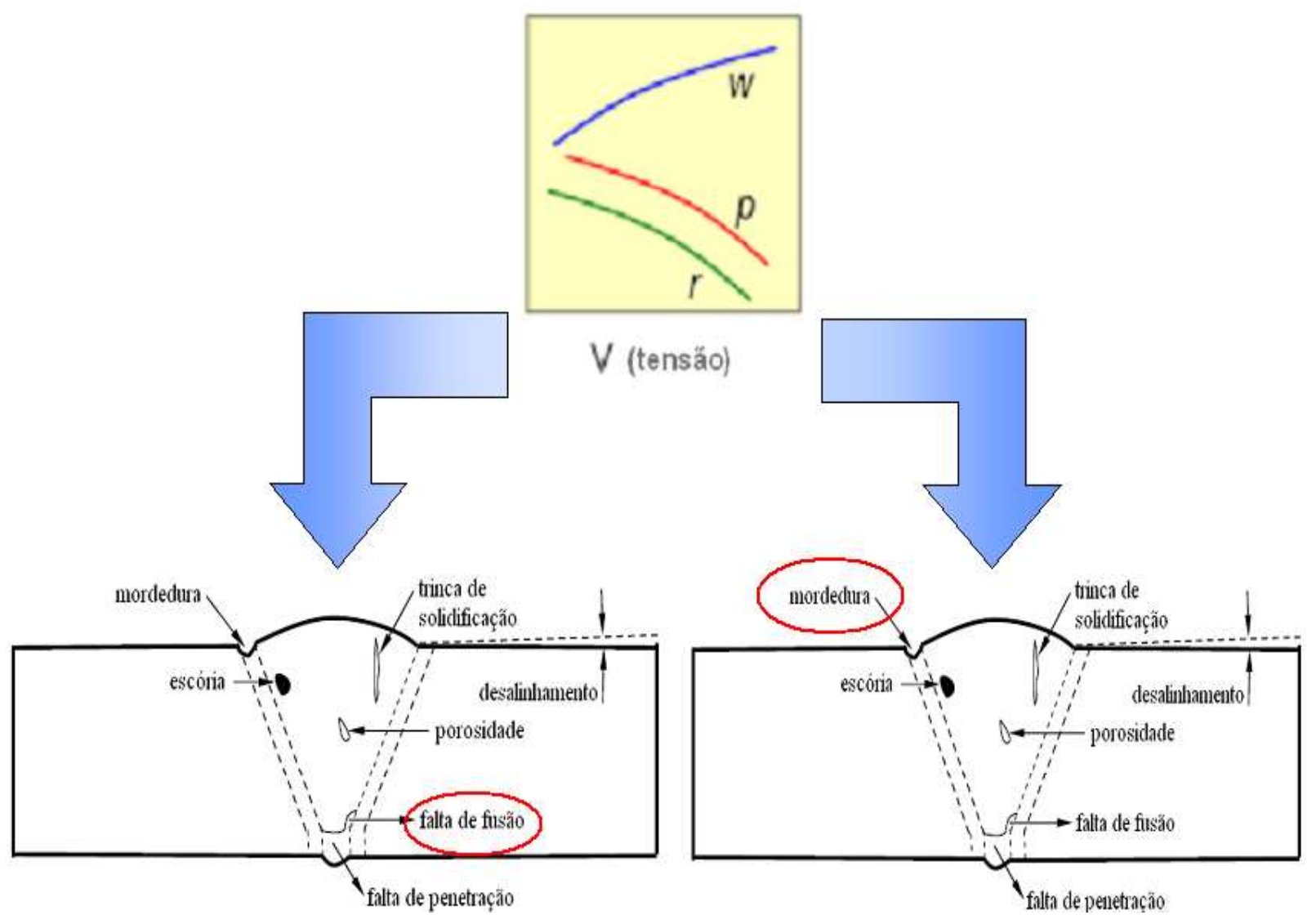

Figura 3.8 - Relação entre tensão do arco e a incidência de defeitos na geometria da solda 


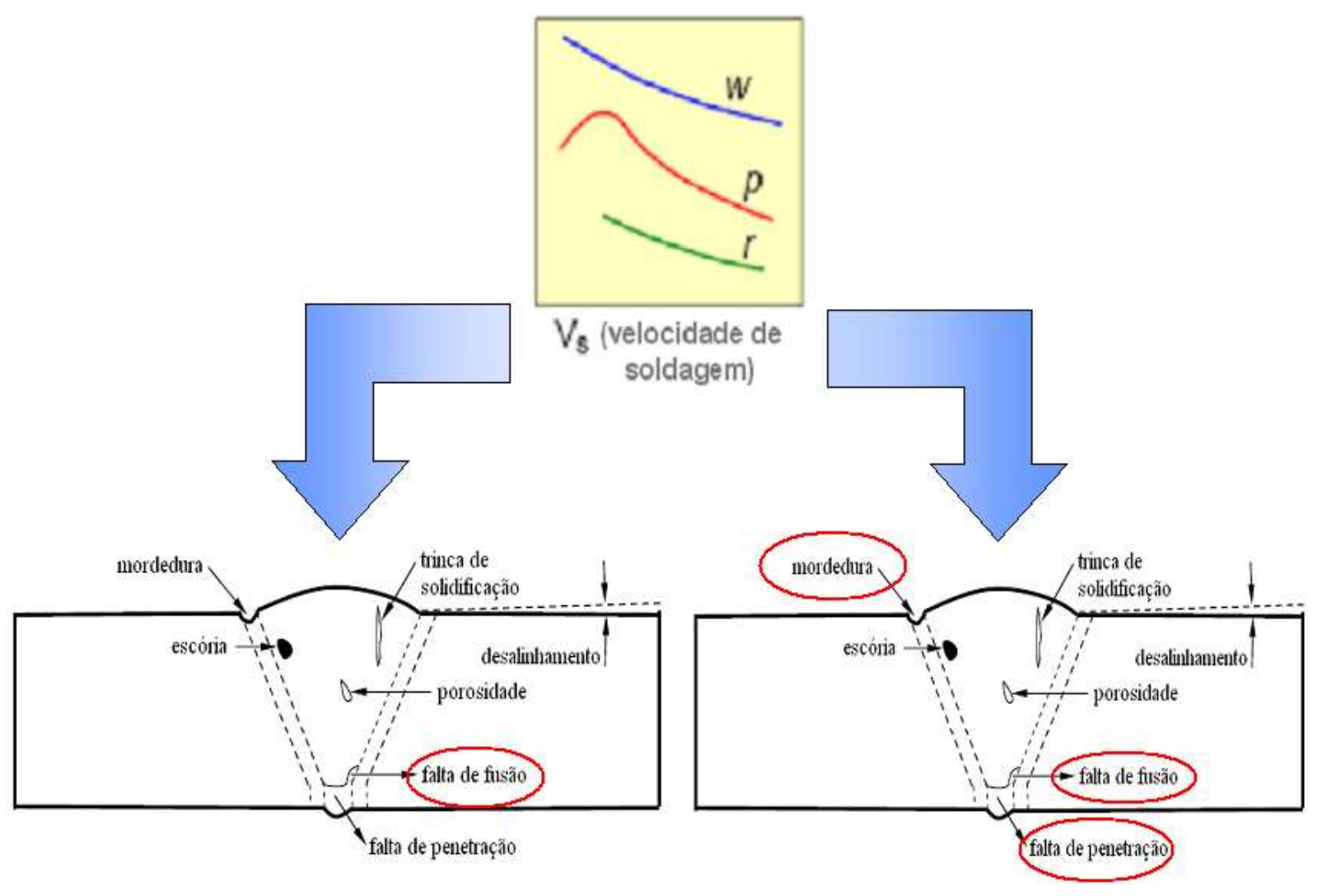

Figura 3.9 - Relação entre a velocidade de soldagem e a incidência de defeitos na geometria da solda

\subsubsection{Gases de Proteção e vazão do gás}

Os gases de proteção utilizados no processo MIG são argônio, hélio uma mistura de ambos. O processo MAG utiliza a mistura de gases inerte com $\mathrm{CO}_{2}$ ou com oxigênio ou ainda o $\mathrm{CO}_{2}$ puro. $\mathrm{O} \mathrm{CO}_{2}$ é mais barato que outros gases de proteção, porém quando submetido a altas temperaturas, o $\mathrm{CO}_{2}$ decompõe-se em $\mathrm{CO}$ e $\mathrm{O}_{2}$. Para impedir, portanto, a formação de $\mathrm{CO}$ e conseqüentemente a formação de porosidade no interior do metal, devido a elevada taxa de resfriamento, utiliza-se silício e manganês como desoxidantes [15].

Quando se utiliza uma mistura de argônio e $\mathrm{CO}_{2}$, é preciso atentar para a porcentagem de argônio existente na mistura, visando estabilizar o arco para minimizar o respingo.

A vazão do gás no processo MIG/MAG se refere à quantidade em litros de gás de proteção espalhada por minuto em torno da poça de fusão, em função da intensidade de corrente. Assim, quanto maior a intensidade de corrente, maior deve ser a vazão do gás de proteção e maior o diâmetro do bocal da pistola. 
A Figura 3.10 mostra as características geométricas principais de um cordão de solda em seção transversal.

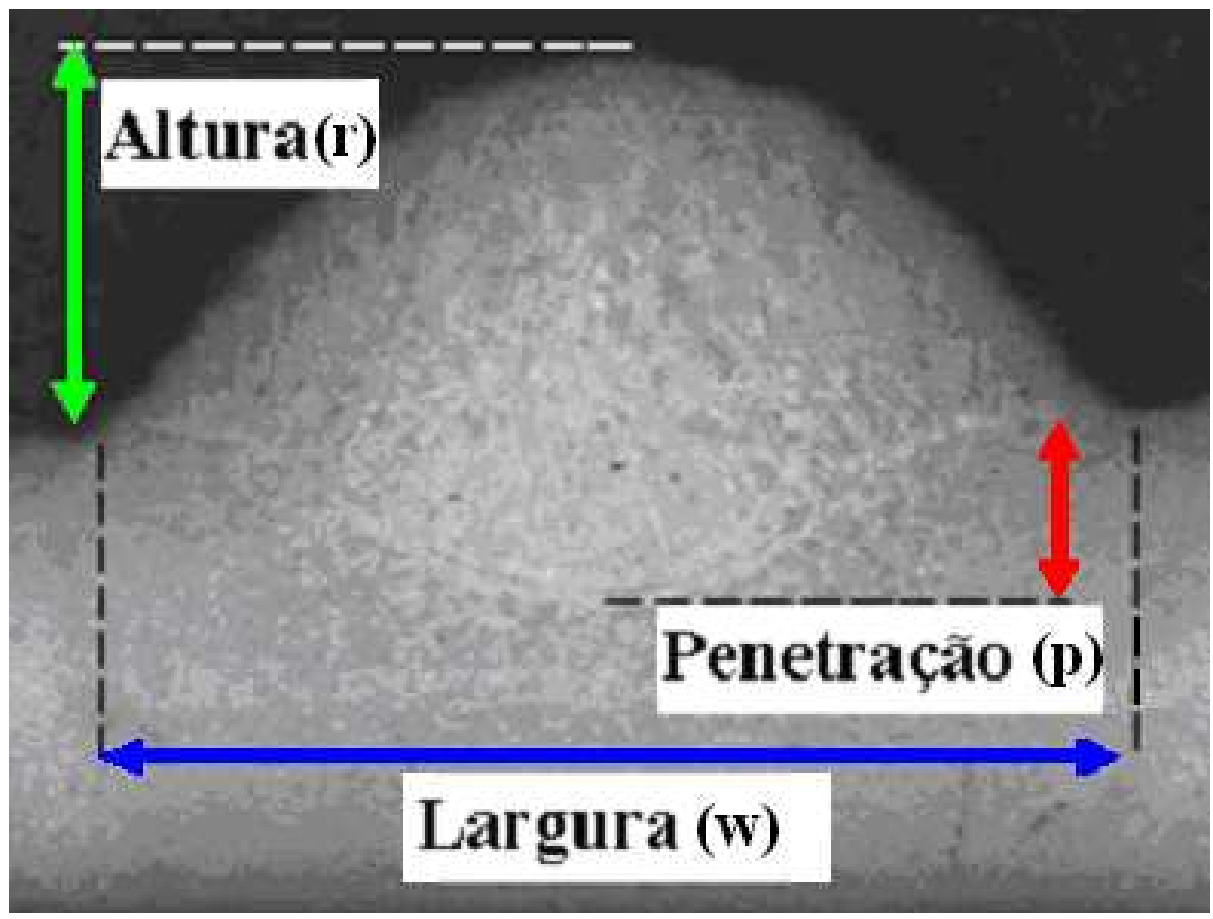

Figura 3.10 - Seção transversal do cordão de solda e suas características principais [18]

\subsubsection{Influência dos parâmetros de soldagem na geometria do cordão}

Processo de soldagem MIG/MAG é importante em muitas operações industriais. O estudo no controle dos modos de transferência metálica é essencial para a alta qualidade dos procedimentos de soldagem. Os parâmetros de solda são os fatores mais importantes que afetam a qualidade, produtividade e custo de junta soldada [18][19].

O tamanho do cordão de solda e sua forma são importantes considerações para projeto de engenharia. Na realidade, a geometria de solda afeta diretamente a complexidade de tempos e ciclos de soldagem e com isso aumenta os custos de fabricação de estruturas de aço e dispositivos mecânicos soldados [20]. Todos os parâmetros que afetam o arco e a soldagem em si devem ser então calculados para obtenção de ótimos resultados.

Alguns parâmetros de soldagem podem ser ajustados durante o processo, como por exemplo a corrente de soldagem, a tensão do arco, a velocidade de soldagem, o ângulo da pistola, o 
comprimento do arame livre, a distância do bocal, a posição e direção de soldagem e a taxa de fluxo de gás [20]. Entretanto outros parâmetros são definidos em uma etapa anterior a soldagem e não podem ser alterados durante o processo, como por exemplo o diâmetro e a composição do arame (elétrodo) e o tipo de gás protetor.

Uma penetração suficiente, taxa de aquecimento adequada e correto perfil da solda levam à boa qualidade da junta soldada. Estes são afetados pela corrente elétrica, pela tensão do arco, pela velocidade de soldagem e pelos parâmetros do gás de proteção [19]. Dentre estes, a intensidade de corrente de soldagem tem o efeito mais intenso na capacidade de fusão, no tamanho da poça da solda, na geometria e na profundidade de penetração. Por outro lado, corrente de soldagem muito baixa causa inadequada penetração e assim acúmulo do metal de solda no metal de base. Quando todos os parâmetros são mantidos constantes, a área da junta soldada se expande com o aumento da tensão. Velocidades de soldagem relativamente baixas, causam acúmulo do metal de solda, grande poça da solda e baixa penetração. Os maiores valores de penetração são obtidos dentro de um valor ótimo de velocidade de soldagem.

Investigações sobre a relação entre os parâmetros do processo de soldagem e a geometria do cordão começaram no início da metade do ano de 1900, atualmente o uso de uma análise de regressão tem sido aplicado na pesquisa de soldagem [21].

Muitos esforços foram conduzidos no desenvolvimento de vários algoritmos na modelagem do arco do processo de solda [22][23]. Os resultados para o processo de soldagem MAG mostraram que a corrente do arco tem a maior influência na geometria do cordão, e que modelos matemáticos derivados de resultados experimentais podem ser usados para predizer com precisão a geometria deste [24]. As pesquisas foram avançando e estudos foram sendo estendidos para outros fatores da soldagem controladores tais como, deposição da solda, efeitos de polaridade, extensão e diâmetro do eletrodo, corrente de soldagem, tensão do arco, velocidade de deslocamento, tipo de fonte de aporte de energia e composição química do fluxo na deposição da solda [19][25].

\subsection{Forças de restrição na soldagem}

Uma significativa quantidade de pesquisa tem sido realizada no dimensionamento da tensão residual e nas distorções em soldagem, como por exemplo, a utilização de métodos de livre- 
distorção de uma chapa não restringida ou da medida de tensão residual de uma chapa restringida após o resfriamento da solda. [26].

Outros métodos foram desenvolvidos para avaliar o efeito da forma do cordão, bem como calcular a força de restrição, como uma função da direção do cordão e da geometria, sob diferentes aberturas de juntas. [27].

Um método para predizer a deformação de soldagem de grandes estruturas soldadas também foi proposto por Jang e Lee [28]. A abordagem utilizada foi uma combinação do método de elementos finitos com medidas experimentais e também com a teoria da deformação inerente, que é a deformação devida à tensão residual imposta pela soldagem. Assumindo que a deformação inerente é a deformação inicial, a deformação de soldagem pode ser calculada facilmente por análise elástica de elementos finitos.

O efeito da sequiência de soldagem em distorção de painéis foi estudado por Tsai et al. [29]. Neste estudo, os comportamentos de distorção, a flexão localizada de chapas e o seu empenamento, foram investigados através do método de elementos finitos. Foi observado que o empenamento não acontece em estruturas com espessuras finas de chapa menores que 1,6mm. Na soldagem, a deformação é causada principalmente pela flexão angular da chapa. O "Método de Junta Rígida" foi desenvolvido para ser efetivo na determinação da seqüência ótima de soldagem para a deformação mínima de painéis.

Ainda, no desenvolvimento de tensões inerentes que surgem durante a soldagem, uma investigação foi conduzida através da técnica do furo de sondagem (“drilled-hole”) e o método de elementos finitos [30]. Os resultados mostram uma correlação clara entre as tensões inerentes induzidas e os parâmetros de soldagem. Adicionalmente, por aquecimento prévio das partes a soldar foi possível reduzir o nível de tensões inerentes no componente e deste modo evitando a formação de trincas por tensão residual.

O efeito do material de adição e da restrição por contração na otimização da tensão em componente soldado, foi também estudado em dois casos: juntas soldadas de topo por arcosubmerso de chapas de aço estrutural e soldagem TIG orbital de aços inoxidáveis super martensíticos tubulares. Foram encontrados em ambos os casos que as forças e as tensões 
residuais transversais à solda poderiam ser reduzidas significativamente selecionando materiais de adição que levam ao overmatching ${ }^{1}$ [31].

A resistência do metal de adição e a distribuição da tensão de componentes restringidos foram examinadas através do monitoramento em tempo real das forças de reação durante a soldagem de uma estrutura. Em particular, os efeitos dos diferentes valores de resistência do material de base e do metal de solda, e a influência na força de reação e nos valores de tensão residual transversal à direção de soldagem [32].

Estes autores observaram que a força de reação final e também o nível de tensão residual na solda de topo multi-passo diminuem com "overmatch" do metal de solda.

Entretanto, pesquisas mais recentes, indicam que juntas soldadas "undermatching" apresentam melhor desempenho à fadiga do que juntas “overmatching” [33][34].

\subsubsection{O fenômeno do "mismatching" nas juntas soldadas}

As juntas soldadas possuem certas características que as tornam diferentes do metal base. As mais importantes, em termos de comportamento à fratura, são:

- Presença de tensões residuais e deformações na solda devido à deformação plástica local, resultante do histórico térmico da solda;

- Alterações metalúrgicas e mecânicas resultantes do histórico térmico da solda: "mismatching" na resistência e ductilidade e "mismatching" na resistência a fratura;

- Existência de descontinuidades geométricas, como defeitos na solda e concentradores de tensões.

De todas estas características citadas acima, o "mismatching" em juntas soldadas exerce um importante papel no comportamento à fratura, tanto em termos de resistência à fratura quanto

${ }^{1}$ Mismatching significa que o metal base e o metal de adição de solda possuem características distintas entre si, e pode ser descrito pelo parâmetro M:

$$
M=\frac{\sigma y w}{\sigma y b}
$$

onde $\sigma y w$ e $\sigma y b$ são, respectivamente, a tensão de escoamento do metal de adição e do metal base. Quando $\mathrm{M}<1$, tem-se o chamado undermatching. Já quando $\mathrm{M}>1$ tem-se o overmatching. 
com relação a comportamento sob deformação. Alguns fatores responsáveis por estas diferenças são:

- O processo de soldagem;

- Os consumíveis;

- A geometria das juntas;

- Os ciclos térmicos de soldagem.

Juntas soldadas "undermatching" são comumente utilizadas em soldagem para reparos, vasos de pressão, pontes e etc., visando prevenir o surgimento de trincas nas soldas. Já juntas com "overmatching" são utilizadas em tubulações, estruturas marítimas, etc, evitando as trincas no metal de adição através da proteção das micro-trincas pré-existentes.

Os efeitos do "mismatching" têm sido bem discutidos na última década, mas somente recentemente o fenômeno foi estruturado em sub-tópicos de estudo, levando os pesquisadores a muitas discussões.

O conceito de mecânica de soldagem foi criado em 1993 com o objetivo de focar a relação entre as propriedades mecânicas e de fratura das juntas soldadas. Foi demonstrado que a resistência à fratura de uma mesma microestrutura na ZAC pode ser alterada drasticamente pela mudança das propriedades do metal de base adjacente.

Em adição à forte dependência entre resistência e tenacidade, existem também outros fatores que podem ser analisados [35]:

- A geometria do corpo de prova ou peça;

- Dimensões da trinca;

- Localização da trinca;

- Mecanismo de fratura;

- Modo de carregamento.

Dependendo das necessidades industriais, diferentes abordagens podem ser utilizadas durante a investigação dos efeitos do "mismatching", sendo do ponto de vista da mecânica da fratura, duas direções podem ser identificadas.

Uma direção foca na pesquisa do comportamento dúctil da junta, com a análise da aplicação do limite de carga. Outra direção aponta para a pesquisa com o objetivo de esclarecer seu efeito nos atuais códigos e normas. 
Também já foram realizados trabalhos de pesquisa utilizando a ferramenta do método dos elementos finitos [34]. Os resultados das simulações mostraram-se satisfatórios, apesar de serem trabalhosos e demonstrarem certas limitações.

Entre os outros métodos de análise empregados para avaliação do "mismatching", também se encontra a aplicação da Integral J em sistemas bi-materiais que apresentam o fenômeno [36]. Os resultados demonstram que o valor da Integral J diminui com o "overmatching".

\subsubsection{Tensão residual da solda e seu efeito na vida à fadiga}

Tensões residuais da solda, introduzidas pelo processo de soldagem, surgem a partir da expansão e contração que ocorre durante o aquecimento e resfriamento da solda, desalinhamento e variação microestrutural em soldagem e zona afetada pelo calor (ZAC). Tensões residuais em soldagem têm dois efeitos deletérios: Primeiramente, elas produzem distorção, e segundo, podem ser a causa de falha prematura especialmente em fratura de fadiga sob carregamentos cíclicos externos [37].

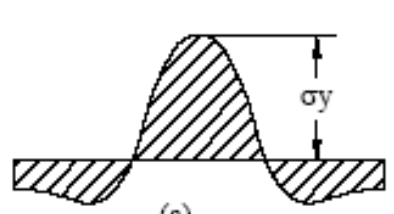

(a)

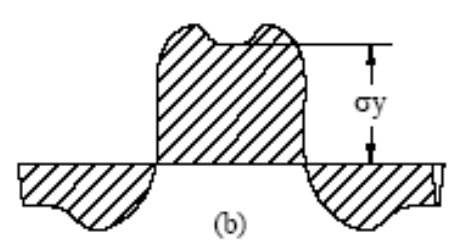

(b)

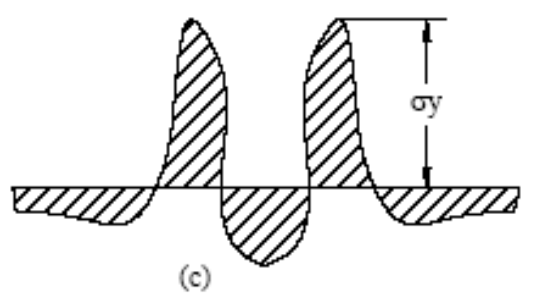

Figura 3.11 - Distribuição da tensão residual (seção transversal) em uma solda de topo (a) aço médio carbono (b) liga de alumínio (c) aço estrutural de alta liga [14]

Foi confirmado que a tensão residual de tração proveniente da soldagem é alta na vizinhança da solda onde sua magnitude é aproximadamente igual ao limite de escoamento do metal da solda [38]. Alguns pesquisadores confirmaram que tensões residuais de tração podem contribuir para diminuir as propriedades de fadiga em juntas soldadas. Por outro lado, tensões compressivas na superfície de soldas podem melhorar a resistência à fadiga de estruturas soldadas. Um estudo do 
efeito das tensões residuais na taxa de propagação da trinca em fadiga mostrou que o efeito da taxa de crescimento de trinca na região de tensão residual da solda poderia ser avaliado em termos da variação de intensidade de tensão efetiva [39].

Outros pesquisadores mostraram que o fator de intensidade de tensão efetiva e a razão de tensão efetiva podem ser aplicados para predizer a taxa de crescimento de trinca por fadiga tanto no campo de tensão residual de tração quanto no campo de tensão residual de compressão, utilizando os dados da taxa de crescimento de trinca do metal de base com diferentes razões de tensão [40][41][42].

Diversos pesquisadores [37][43][44] informaram, com base em suas experiências, que a magnitude da tensão residual de tração pode se aproximar da força limite de escoamento do material em alguns locais críticos da junta soldada. Tensões residuais de soldas ficaram conhecidas, depois de muitos anos de pesquisa, como um dos mais críticos fatores que podem influenciar as propriedades de fadiga de juntas soldadas.

O crescimento de trinca de fadiga em exemplares do metal da solda, da zona afetada pelo calor e do metal de base do alumínio Al 5456-H117, foi estudada em chapa soldada de topo. As medições do deslocamento de abertura da trinca (Crack Opening Displacement, COD) foram obtidas durante os testes de crescimento de trinca de forma que puderam ser determinados os efeitos das cargas de abertura da trinca e da tensão residual. Com base no $\Delta \mathrm{K}_{\text {nom }}$ as taxas de crescimento da trinca foram investigadas desde o metal de base Al-5456, na zona afetada pelo calor e no metal soldado. Estes resultados puderam ser conciliados assumindo-se que a taxa de crescimento da trinca é dada pela variação de um fator de intensificação de tensão efetivo, dado pela carga de abertura de trinca, como proposto por Elber $^{1}[45]$.

A conclusão foi que as diferentes taxas de crescimento de trinca por fadiga, medidas para os três materiais, são resultados das diferenças nas tensões residuais desenvolvidas na solda [46].

\footnotetext{
${ }^{1}$ Segundo Schijve "Elber conduziu um teste de crescimento de trinca em um espécime com uma trinca central Figura 3.12. Depois de um crescimento de trinca significativo, mas antes da falha, ele quis abrir a trinca cortando os ligamentos sem falha. Depois que ele mesmo cortou o primeiro ligamento, ele observou que o espécime estava torcido de maneira estranha. Elber entendeu que isto tinha ocorrido devido à deformação plástica estimulada pela trinca de fadiga. Ele então fez sua famosa medição de fechamento de trinca” [5].
} 

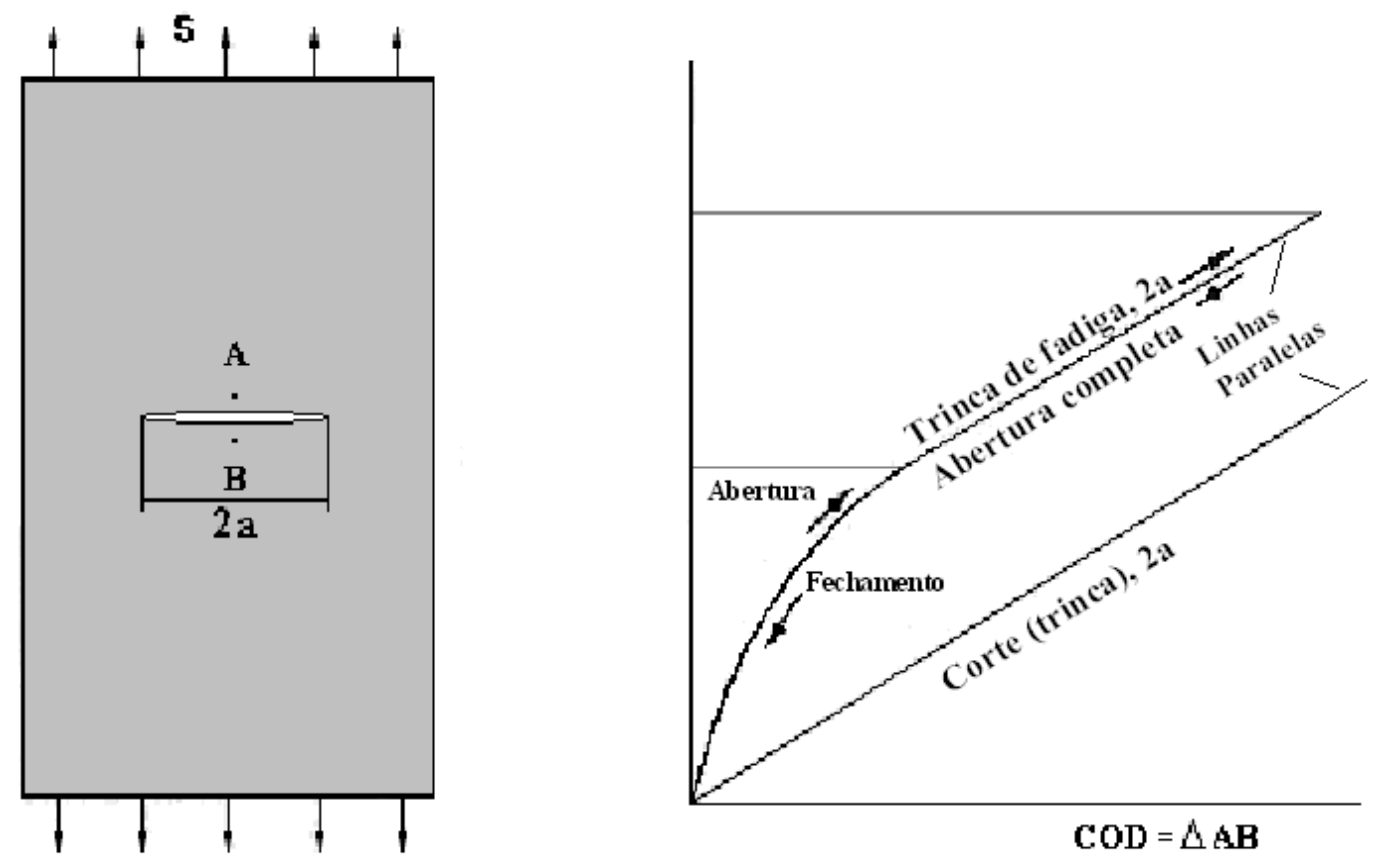

Figura 3.12 - Medida do deslocamento de abertura de trinca mostrando a ocorrência de plasticidade induzida pelo fechamento de trinca a uma tensão positiva de acordo com Elber [5].

\subsection{Fadiga}

A vida em fadiga em um material, como apresentado por Schijve [5] é dividida em múltiplas fases: nucleação da trinca, crescimento de micro-trinca, crescimento de macro trinca e falha, como esquematizado na Figura 3.13.

A nucleação de trinca está associada com o escorregamento cíclico e é controlado pela concentração de tensão na superfície do material e na deformação local. Em metais puros e isentos de defeitos observa-se a nucleação da trinca em bandas de deformação (PSBs, Persistent Slip Bands). Em materiais de engenharia, entretanto, defeitos como inclusões e poros podem contribuir para a nucleação da trinca.

Crescimento de micro trinca, um termo agora referido ao regime de crescimento de pequenas trincas (menores que $1,27 \mathrm{~mm}$ ), é o crescimento de trincas nucleadas devido à inclusão ou porosidade que medem de 1-10 $\mu \mathrm{m}$ de comprimento. Schijve mostrou que para superfícies polidas de metal puro e para ligas comercias, a formação de uma pequena trinca em torno de $100 \mu \mathrm{m}$ em tamanho pode consumir $60-80 \%$ da vida em fadiga. Este é o motivo pelo grande interesse no comportamento de crescimento de pequenas trincas. 
Crescimento de trincas longas e a falha final são fases onde os parâmetros da mecânica da fratura têm apresentado resultados satisfatórios na correlação e na predição de crescimento de trinca e fratura por fadiga.

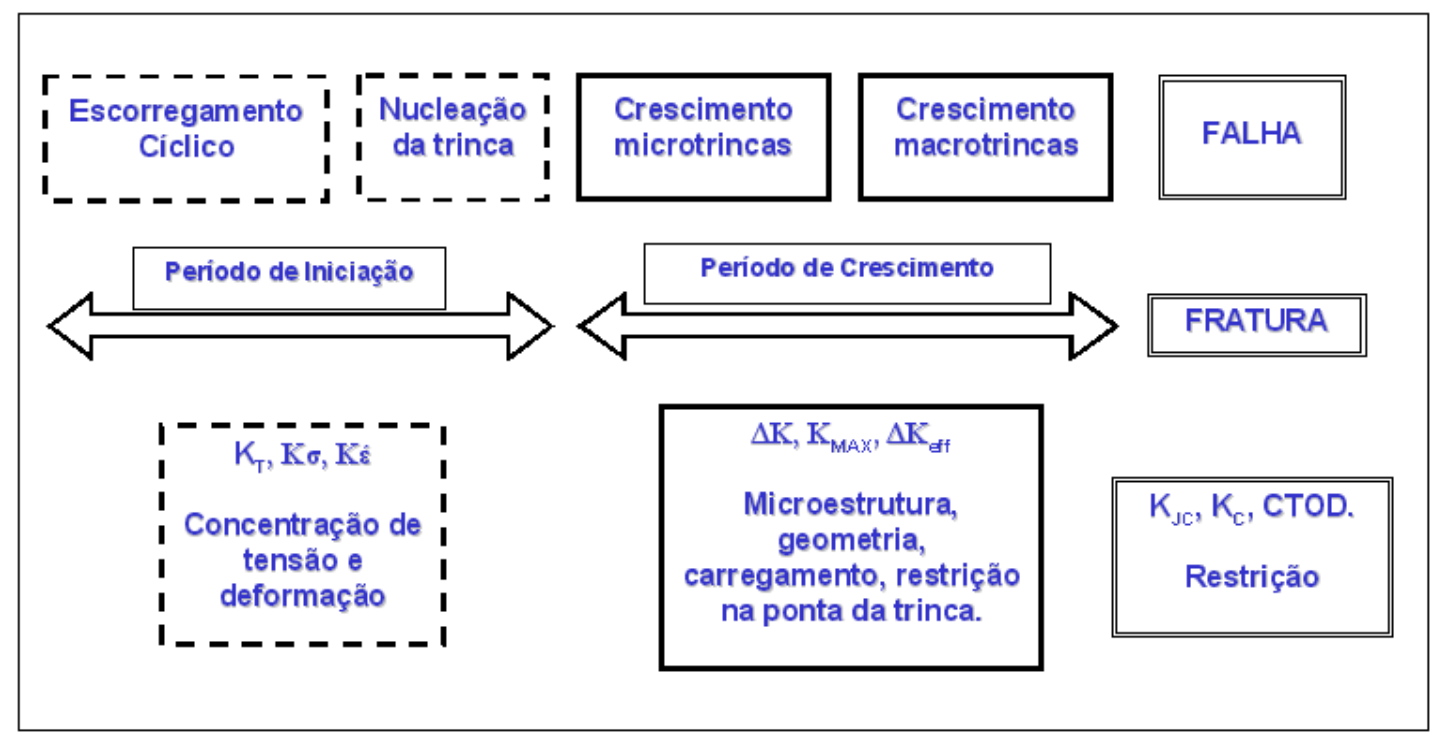

Figura 3.13 - Diferentes fases da vida em fadiga e fatores relevantes. Adaptado de Schijve [5]

Para motivos de análise, a vida em fadiga de estruturas soldadas pode ser dividida em duas partes: (1) fase de iniciação de trinca, e (2) fase de propagação da trinca. O comportamento em propagação de trincas por fadiga é tipicamente descrito em termos de taxa de crescimento de trinca ou extensão da trinca por ciclo de carregamento, gráfico $(\mathrm{d} a / \mathrm{d} N)$, contra a variação do fator de intensidade de tensão, chamado aqui de $\Delta K$.

A partir da hipótese de que a geometria da solda pode diferir em vários tipos de juntas soldadas, relações empíricas tradicionais se tornam inválidas em alguns casos e novos modelos devem ser elaborados para distribuição da tensão local e cálculo preciso do fator de intensidade de tensão.

Por exemplo, um modelo de mecânica da fratura e uma abordagem experimental foram utilizados para investigar o efeito da espessura da chapa na resistência mecânica de cordões de solda sob carregamento axial [47]. Em outro estudo, foi utilizado um modelo de fratura linear elástica para predizer a vida em fadiga de juntas soldadas em T, e a importância do raio de curvatura na margem da solda na resistência da junta soldada [48]. 
A experiência tem mostrado que a maioria das falhas de estruturas de engenharia soldadas é associada com crescimento de trinca de fadiga. Análise de crescimento de trinca por fadiga freqüentemente é requerida para projeto de estruturas, por exemplo, como a análise de tolerância de dano (DTD ou Damage Tolerance), predição de vida residual quando uma trinca de fadiga inesperada é encontrada em um componente estrutural e falha segura (Fail Safe) quando um componente de um conjunto falha, este não pode comprometer a integridade estrutural do conjunto como um todo [7].

\subsubsection{Comportamento da trinca de fadiga}

A literatura em propagação de trinca por fadiga de estrutura soldada foi estudada detalhadamente, através de medições da taxa de crescimento de trinca durante testes de fadiga em amplitudes constantes em amostras soldadas e não soldadas de liga de alumínio 5083-H321 [14]. Através do uso de métodos de elementos finitos foi determinado o fator de intensidade de tensão para diferentes comprimentos de trinca, considerando, entretanto, as características tridimensionais da geometria do cordão de solda. Para determinar o fator de intensidade de tensão e avaliar os efeitos do fechamento de trinca da solda devido às tensões residuais, foi medido os deslocamentos de abertura na ponta da trinca. Foi encontrado que taxas de crescimento de trinca em chapas soldadas são da mesma ordem de magnitude do material original, quando fatores de intensidade de tensão efetivos eram aplicados.

\subsubsection{Trinca de fadiga em juntas soldadas}

Por muitos anos experiências de crescimento trinca por fadiga foram conduzidas baseadas em normas ASTM E-647 que é projetada para materiais usuais, p.ex. aço e alumínio. Dois tipos de espécimes, compacto em tração (trinca na extremidade) e tração com trinca centrada (trinca no centro), são recomendados neste código para testes de $\mathrm{d} a / \mathrm{d} N$.

Fatores de intensidade de tensão são calculados na forma, $\Delta \mathbf{K}=\mathbf{K}_{\mathbf{m a x}}-\mathbf{K}_{\min }$ por relações empíricas derivadas a partir de análise de elementos finitos. Embora este método seja validado para dar bons resultados para materiais usuais, ainda precisa ser revisado para determinar comportamento de propagação de trinca de fadiga em juntas soldadas. Muitos pesquisadores 
[49][50] mostraram que, para juntas soldadas, fatores geométricos da solda e as tensões residuais da solda podem afetar os dados de crescimento de trinca em fadiga comparados com experimentos.

Foi confirmado por alguns pesquisadores que o método aceitável para testes $\mathrm{d} a / \mathrm{d} N$ em juntas soldadas é a substituição da variação do fator de intensidade de tensão nominal, $\Delta \mathrm{K}$, pela variação do fator de intensidade de tensão efetiva, $\Delta \mathbf{K}_{\mathrm{eff}}=\mathbf{K}_{\mathbf{m a x}}-\mathbf{K}_{\mathbf{o p e n}}$, os quais contribuem para a influência de fechamento de trinca e tensão residual da solda [50].

Para obter fatores de intensidade de tensão efetivos na presença de campo de tensão residual de solda, carga de abertura de trinca, $\sigma_{\text {open }}$ tem que ser determinada. $\mathrm{O} \sigma_{\text {open }}$ pode ser calculado analisando a curva de carregamento de fadiga para abertura da ponta da trinca, Figura 3.14, que pode ser traçada durante a propagação da trinca de fadiga utilizando extensômetros para medição do deslocamento da abertura na ponta da trinca.

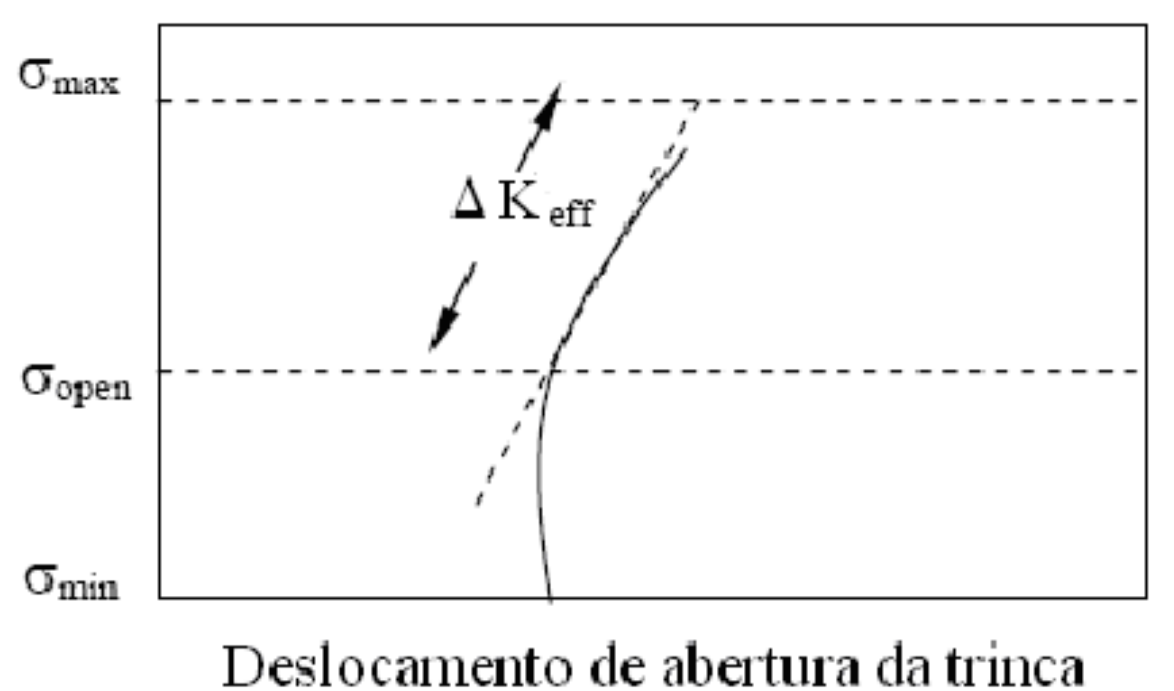

Figura 3.14 - Tensão versus curva de deslocamento de abertura da trinca [51]

\subsubsection{Crescimento de trinca de fadiga em juntas soldadas}

Considerando crescimento de trinca de fadiga em juntas soldadas, a porcentagem da fase de propagação de trinca na vida da fadiga total é muito dependente de qualidade da solda, que inclui sua geometria, defeitos iniciais na solda, tensões residuais de soldagem e condições de tensão locais. Desde então defeitos de soldagem podem freqüentemente existir na vizinhança da 
solda, concentrações de tensão locais ao redor de descontinuidades. Estes defeitos do tipo trincas, quando sujeito a cargas de fadiga cíclicas externas, começam crescer quase imediatamente, de forma que, para juntas soldadas, a vida total de fadiga é principalmente dominada pela fase de propagação de trinca.

Uma pesquisa foi conduzida para investigar a iniciação de trinca de fadiga e comportamentos de propagação de aço soldado de estrutura tubular. Os resultados obtidos indicaram que a vida de crescimento de trinca era de $75 \%$ a $89 \%$ da vida total para todas as juntas soldadas testadas [52]. Conforme sugerido nos capítulos anteriores, a tensão residual de tração pode diminuir significativamente as propriedades de fadiga em juntas soldadas [53][54]. Por outro lado, tensão de compressão na superfície da solda, introduzida por tratamento pós-soldagem, pode melhorar as propriedades de fadiga de estruturas soldadas. Investigações prévias [40] têm indicado que tensão residual na solda tem efeitos significantes na fase de iniciação de trinca de fadiga e no estágio inicial de propagação de trinca.

Portanto a literatura indica que defeitos na solda são concentradores de tensão residual e podem, portanto, abreviar a vida à fadiga de estruturas soldadas sujeitas a carregamentos cíclicos.

\subsubsection{Fatores que afetam a vida à fadiga de juntas soldadas}

Embora representações de crescimento de trinca de fadiga sejam características negativas de materiais, muitos fatores têm que ser levado em conta quando dados de crescimento de trinca de fadiga estão sendo medidos ou sendo solicitados para predição de vida de fadiga, especialmente em juntas soldadas. Tais fatores são descritos abaixo.

\subsubsection{Geometria de solda}

Foi dito que comportamentos de crescimento de trinca de fadiga de juntas soldadas são altamente dependentes não só nos materiais e condições de carga, mas também em geometria de solda, como ângulo da margem da face de solda $(\boldsymbol{\alpha})$, raio da margem da solda $\mathbf{R}_{\mathbf{t}}$, espessura da chapa (t), largura do cordão de solda (w) e altura do reforço (h). 


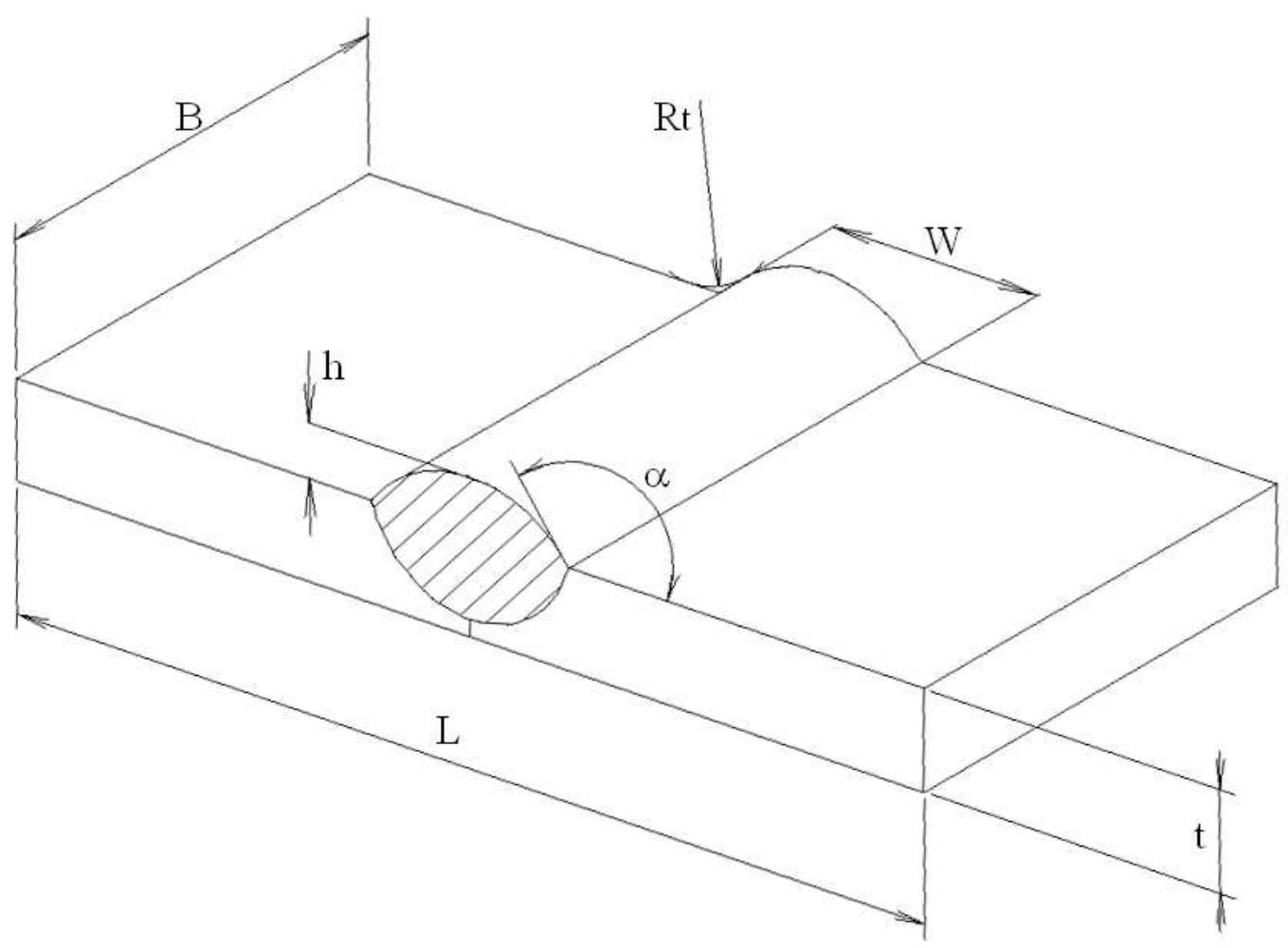

Figura 3.15 - Características geométricas do cordão de solda de topo

Os resultados de um estudo dos efeitos da geometria do cordão de solda nas propriedades de juntas $\mathrm{T}$ mostraram que a relação da espessura da chapa principal e o raio da margem da solda (t/Rt) são os fatores mais importantes para as propriedades de fadiga de juntas soldadas. Com espessuras reduzidas de chapas, a resistência à fadiga e a vida aumentarão no caso deste tipo de junta soldada [48]. Entretanto, para soldas de topo MAG de 25 - 35mm em ligas de Al5083-O, Al5083-H116, Al5456-H116 e Al5456-H117, as investigações concluíram que o ângulo da margem da face do cordão da solda é o principal fator na determinação da vida de fadiga de juntas soldadas [55].

A influência de várias características geométricas do cordão de solda na propagação de trinca em fadiga em juntas de topo em chapas de $9 \mathrm{~mm}$ a $32 \mathrm{~mm}$, foi estudada e reportada. As características geométricas que mais influenciam no comportamento de fadiga são: ângulo da margem da face da solda, raio da margem da solda, espessuras de chapa e raio da ponta da mordedura. Estas características geométricas influenciam principalmente na fase de crescimento de trinca e este comportamento pode ser melhorado com a modificação de algumas características geométricas como, aumento do raio da margem da solda, diminuição do ângulo 
da margem da face da solda, eliminação da mordedura na margem da face da solda [40][42]. Por outro lado, outros pesquisadores [56], propuseram medidas diferentes para melhorar a resistência à fadiga destas juntas, por exemplo: reduzindo o ângulo da margem da face da solda de $60^{\circ}$ para $20^{\circ}$ registro-se um aumento da resistência à fadiga de $51 \%$ a $1,1 \times 10^{5}$ ciclos, aumentando o raio da margem da solda de $0 \mathrm{~mm}$ para $0.25 \mathrm{~mm}$ houve um aumento da resistência à fadiga de $21 \%$ a $1,1 \times 10^{5}$ ciclos. Estes autores também investigaram o efeito do préaquecimento na tensão residual próximo a margem da solda. Os resultados revelam que níveis moderados de pré-aquecimento podem reduzir as magnitudes de tensão residual, conforme mostrado na Figura 3.16.

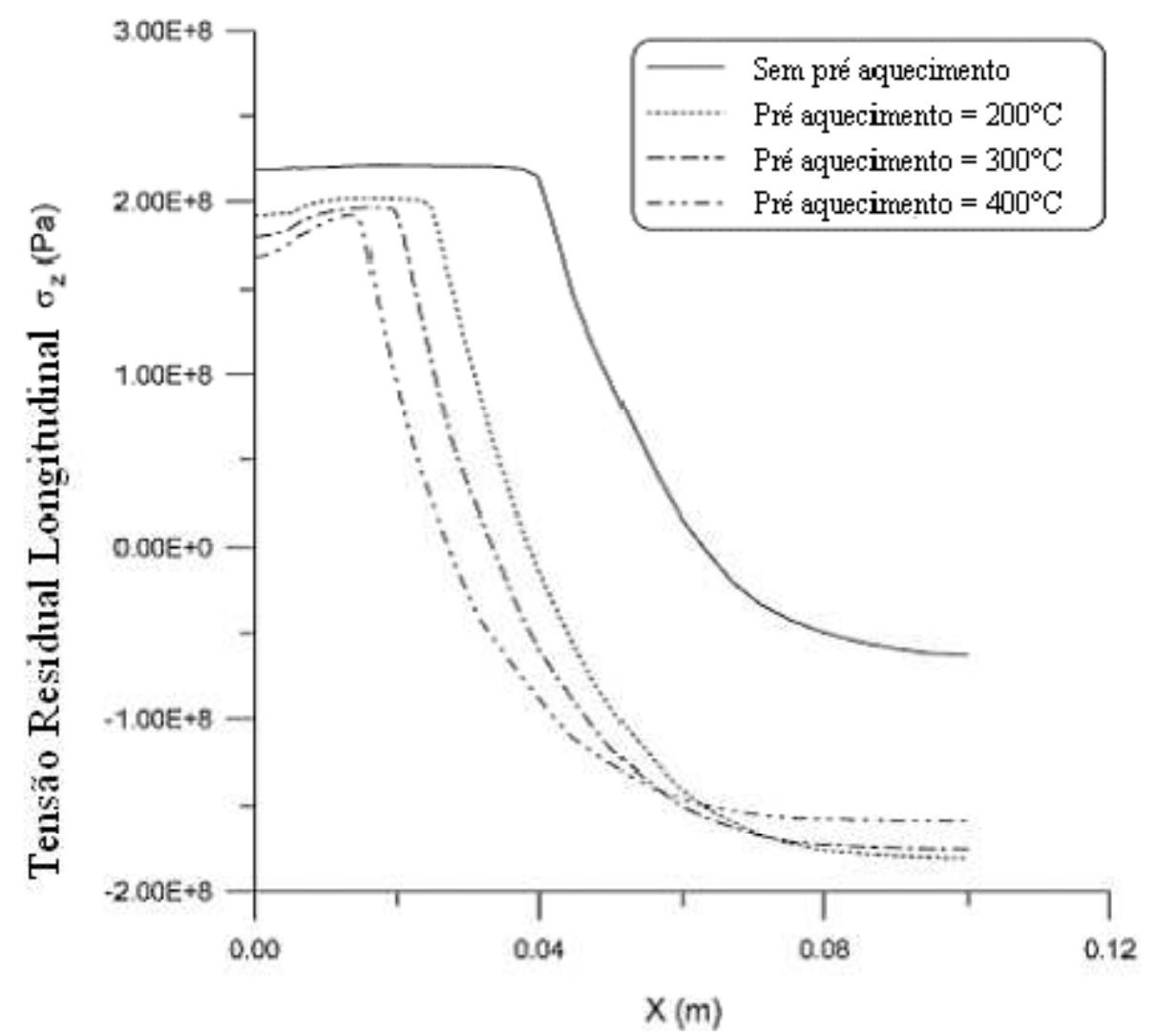

Figura 3.16 - Tensão residual longitudinal para diferentes temperaturas de pré-aquecimento [56]

O efeito da forma da seção transversal da solda na vida à fadiga também foi investigado para juntas T, para várias espessuras de chapa, comprimentos e profundidade de cordão [57]. Cordão de solda com forma triangular e perna do cordão (Hm), Figura 3.17 ligeiramente maior possui um melhor comportamento à fadiga. Além disso, foi investigado também o efeito da 
profundidade de penetração do cordão na resistência à fadiga, os resultados mostraram que o aumento da penetração melhora a resistência à fadiga, conforme mostrado na Figura 3.18.

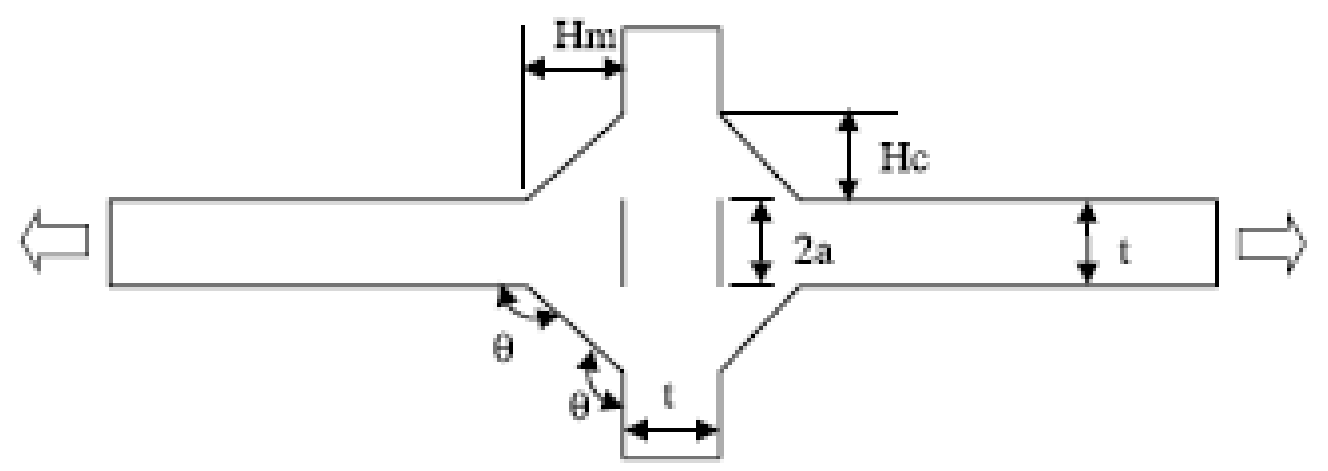

Figura 3.17 - Características geométricas da junta "T" [57]

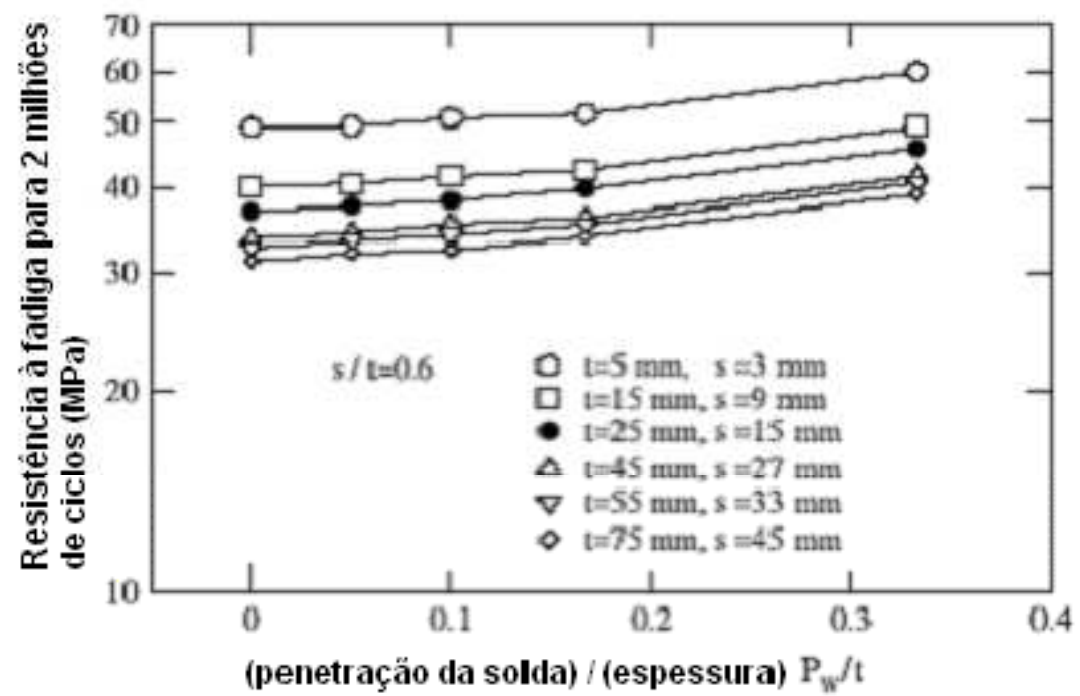

Figura 3.18 - Relação entre resistência à fadiga e profundidade de penetração da solda [57]

\subsubsection{Defeitos de solda}

Defeitos de solda são imperfeições ou descontinuidades produzidas na solda devido ao processo. Os principais defeitos são: porosidade, penetração insuficiente, inclusões de escória, fusão incompleta, desalinhamento, mordeduras e perfil da solda irregular. Estes defeitos de 
solda podem influenciar significativamente o campo de tensão residual na vizinhança da solda quando o componente soldado é sujeito a carregamento cíclico.

Na maioria dos casos, defeitos de solda conduzem a concentração de tensão severa e assim aceleram o crescimento de trinca de fadiga.

O efeito da falta de penetração e da falta de fusão foi estudado no comportamento à fadiga de soldas de topo em ligas de alumínio [55]. Estes defeitos podem reduzir a vida de fadiga da solda, embora defeito de falta de fusão, geralmente seja menos sério que defeito de falta de penetração.

Além disso, os efeitos de descontinuidades internas no desempenho de fadiga em solda com reforços, são mínimos. O efeito da porosidade na resistência à fadiga de juntas soldadas deste tipo, é mais significativo quando o reforço da solda é removido, comparado com a solda com reforço intacto [58]. No entanto, quando a quantidade de porosidade é menor, cordão de solda com reforço removido tem vida mais longa. Em outras palavras, quando existe em cordões de solda um nível relativamente alto de defeitos internos como porosidade, inclusões, falta de fusão e falta de penetração, e quando o reforço do cordão é removido, este pode exibir vida mais curta em comparação com soldas com o cordão intacto.

Trincas na margem da solda são encontradas freqüentemente em muitas estruturas soldadas importantes. A habilidade para avaliar os efeitos destas na vida à fadiga de estruturas soldadas é então de significado prático. Para conduzir esta avaliação são necessárias soluções seguras para o fator de intensidade de tensão.

Soluções para o fator de intensidade de tensão existentes são principalmente derivadas de modelos 2-D de deformação plana na extremidade da trinca. Porém foi reconhecido que trincas de fadiga na margem da solda não podem ser representadas com precisão através de modelos 2$\mathrm{D}$, porque os efeitos da geometria do perfil da solda não são levados em conta. Alguns pesquisadores [52] desenvolveram modelos numéricos 3-D que realçam as limitações de métodos 2-D. Devido a características excepcionais do processo de solda, muitos fatores, como geometria de solda, tensões residuais de soldagem, mudanças metalúrgicas e micro-estruturais e defeitos da soldagem têm que ser levados em conta quando avaliado as propriedades de estruturas soldadas. 


\subsubsection{Materiais e Processos}

Composição química e condição de soldagem de materiais, inclusive metal de base e material de adição podem afetar taxas de crescimento de trinca em fadiga de juntas soldadas [37]. Materiais diferentes têm propriedades e características mecânicas diferentes sob carregamento cíclico. A transformação de fases acontecerá na maioria dos tipos de aços, quando sujeitos ao processo de soldagem. Tensões residuais serão introduzidas por estas mudanças de fase em regiões como a margem da solda e zona afetada pelo calor (ZAC).

Geralmente estas tensões residuais tendem a ser de tração e conseqüentemente reduzem o desempenho à fadiga de juntas soldadas. A magnitude desta influência é dependente no tipo de material. No caso de aço austenítico inoxidável e liga de alumínio 5083, entretanto, nenhuma mudança de fase acontece na ZAC e conseqüentemente nenhuma tensão residual é possível devida à mudança de fase, embora estes materiais possam sofrer perda de resistência significativa devido ao aquecimento durante o processo de solda. Processos de soldagem diferentes também têm efeitos diferentes nas propriedades de fadiga de juntas soldadas. Alguns métodos de soldagem, como por exemplo o de arco-submerso, causam contribuição de calor elevada nas juntas soldadas, produzindo tensões residuais mais altas. Como previamente mencionado, os defeitos introduzidos durante o processo de soldagem como mordeduras, falta de fusão, falta de penetração, desalinhamento, porosidade e perfis defeituosos também podem ter influência significante nas propriedades de fadiga de juntas soldadas. 


\section{OBJETIVOS}

O presente trabalho teve por objetivo verificar o efeito de defeitos geométricos em uma junta soldada do tipo sobreposta na vida à fadiga de um eixo traseiro veicular do tipo interdependente. Eixos interdependentes, conhecidos na literatura de engenharia automobilística como "twistbeam” são os mais comuns eixos utilizados em veículos de tração dianteira. Normalmente tratase de uma estrutura de aço soldada, de tubos conformados, vigas e suportes estampados ou componentes forjados, ou a combinação destes.

Como estrutura, estes eixos são soldados pelo processo MIG/MAG, comum em operações de junção de componentes na indústria de automóvel, onde, atualmente, são realizados por meios de robôs.

Considerando que eixos interdependentes possuem regiões críticas de tensão mecânica, por sua geometria complexa e carregamento aleatório em operação, foi verificado então a vida à fadiga da junta soldada na região de maior tensão mecânica, sob efeito de defeitos no cordão de solda.

Para proporcionar a ocorrência de defeitos na junta soldada, os parâmetros de soldagem primários (corrente, tensão e velocidade) foram variados de maneira controlada, e combinados em duas classes, versão A e versão B.

Os eixos confeccionados nas duas versões foram submetidos ao um ensaio de torção, reproduzindo os esforços que o eixo recebe quando as rodas do lado direito e esquerdo transpassam ondulações no piso de maneira alternada, até que uma ou mais trincas de fadiga atingissem entre 2 e $5 \mathrm{~mm}$ de comprimento.

Como resultado deste trabalho procurou-se gerar dados que possibilitassem:

- determinar os valores ótimos para a corrente, tensão e velocidade de soldagem para o projeto da junta sobreposta do eixo;

- determinar o efeito dos parâmetros primários de soldagem na incidência de defeitos na solda;

- verificar as condições microestruturais para os diferentes parâmetros aqui utilizados;

- medir o desempenho à fadiga das duas classes de eixos aqui estudados e correlaciona-los com os fatores geométricos, defeitos e microestrutura do cordão de solda. 


\section{MATERIAIS E MÉTODOS}

Os ensaios experimentais foram executados diretamente no eixo traseiro, o conjunto soldado é caracterizado por uma geometria bastante complexa. Embora executar os ensaios diretamente no eixo seja custoso, não é possível substituí-lo por corpos de prova normalizados, devido ao papel importante que ele possui na integridade estrutural e comportamento dinâmico do veículo, pois não é possível garantir a transferibilidade destes ensaios em corpos de prova padronizados aos resultados do eixo em serviço.

Para poder compreender o papel do eixo traseiro no veículo é necessário mostrar detalhadamente sua geometria, seus subcomponentes e o processo tecnológico empregado em sua fabricação.

\subsection{O Eixo Traseiro}

\subsubsection{Características físico-geométricas do eixo}

O eixo traseiro, objeto deste trabalho, é composto de uma viga com secção transversal em "V", dois braços tubulares (lado direito/lado esquerdo), dois reforços tipo "mão francesa", denominada aqui como escoras, apoios de mola, suportes de amortecedor, tubo suportes para coxinização e suportes de freio (Figura 5.1).

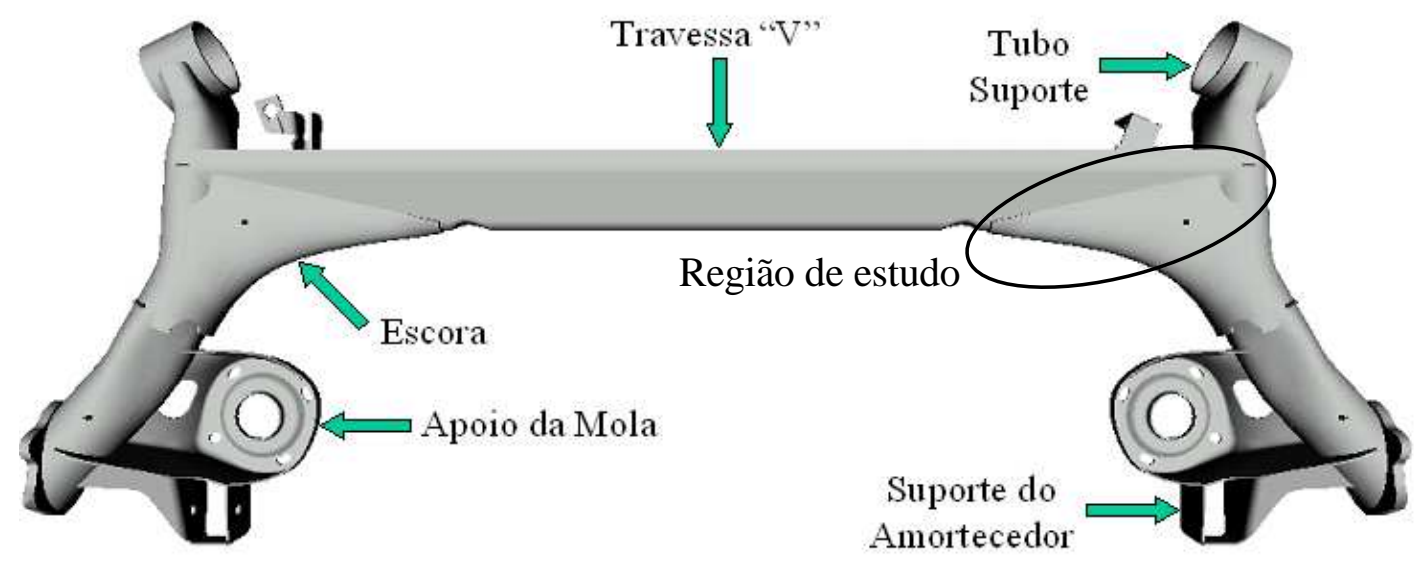

Figura 5.1 - Conjunto eixo traseiro soldado e seus componentes 
A travessa "V", posicionada transversalmente ao veículo, trata-se de uma peça estampada de $6 \mathrm{~mm}$ de espessura e $1100 \mathrm{~mm}$ de comprimento. É o sub-componente principal do conjunto, sua forma, espessura, posição de giro e sua disposição no conjunto determina a rigidez torcional do eixo, bem como o centro de giro instantâneo, importante para a cinemática da suspensão.

Os braços tubulares, posicionados longitudinalmente ao veículo, promovem juntamente com a viga transversal, a estabilidade em curvas do veículo e transmitem os movimentos das rodas ao conjunto. Trata-se de um tubo de diâmetro 70 x 370 e 4,5mm de espessura, conformado a frio (por estampagem).

As escoras interligam os braços longitudinais a travessa "V" por meio de cordões de solda e promovem rigidez e estabilidade ao conjunto. São chapas estampadas de 3,5mm de espessura.

O apoio da mola e o suporte do amortecedor acomodam a mola e o amortecedor, respectivamente. São componentes estampados que estão soldados entre si e ao braço longitudinal.

O tubo mancal recebe o coxim ou mancal de borracha do eixo, responsável pela articulação, promovendo a cinemática do conjunto. Dependendo da sua configuração geométrica, também pode ser responsável em minimizar o efeito de sobresterçamento do veículo, corrigindo o ângulo de convergência das rodas em curvas.

\subsubsection{Características mecânicas e composição química dos componentes e metal de adição.}

A matéria-prima empregada para a fabricação dos componentes do eixo segue um padrão de variação de suas propriedades físico-químicas, normais de um processo produtivo em alta escala de fabricação. Estas variações ou dispersões são aceitáveis quando mantidas dentro de um intervalo conhecido, pré-estabelecido. Portanto os componentes que formam o eixo interdependente, ou qualquer outro componente de um veículo possuem características que podem variar de peça à peça, dentro de uma faixa conhecida, que no caso dos componentes do eixo estão indicados na Tabela 5.1 e Tabela 5.2.

Esta variação, permitida por normas e padrões de produção internacionais, não influenciou sobre os resultados aqui apresentados. 
Tabela 5.1 - Valores permitidos para composição química dos componentes de aço (metal de base) e metal de adição

\begin{tabular}{|c|c|c|c|c|c|c|c|c|}
\hline & \multicolumn{7}{|c|}{ Composição Química } \\
\cline { 2 - 9 } & $\mathbf{C \%}$ & $\mathbf{S i} \%$ & $\mathbf{M n \%}$ & $\mathbf{P \%}$ & $\mathbf{S \%}$ & $\mathbf{A l \%}$ & $\mathbf{T i} \%$ & $\mathbf{N b} \%$ \\
\hline Escora & $0,10 \max$ & ----- & 0,2 a 0,45 & 0,030 & 0,035 & 0,02 a 0,07 & ------- & ------- \\
\hline Travessa "V" & $0,14 \max$ & 0,30 & 0,3 a 1,4 & 0,02 & 0,03 & 0,02 a 0,07 & $0,001 \max$ & $0,08 \max$ \\
\hline AWS ER-70 S3 & 0,06 a 0,15 & 0,8 a 1,5 & 1,4 a 1,85 & $<0,025$ & $<0,035$ & ------- & ------- & ------- \\
\hline
\end{tabular}

Tabela 5.2 - Valores permitidos de resistência mecânica dos componentes e metal de adição

\begin{tabular}{|c|c|c|c|}
\hline \multirow{2}{*}{} & \multicolumn{2}{|c|}{ Características Mecânicas } \\
\cline { 2 - 4 } & $\sigma e(\mathbf{M P a})$ & $\sigma \mathbf{r}(\mathbf{M P a})$ & Alongamento (\%) \\
\hline Escora - espessura nominal 3,5mm & $215-285$ & 320 a 390 & 32 mínimo \\
\hline Travessa - espessura nominal $\mathbf{6 m m}$ & $360 \mathrm{~min}$ & 500 a 600 & 22 mínimo \\
\hline AWS ER-70 S3 - $\phi$ do arame 1,2mm & $480 \mathrm{~min}$ & 400 min & 22 mínimo \\
\hline
\end{tabular}

\subsection{O processo de soldagem}

O processo de soldagem automático utilizado, os meios, equipamentos e métodos são os mesmos utilizados na fabricação do eixo para montagem de veículo na fábrica.

Como descrito anteriormente o processo possuí duas classes de parâmetros, os parâmetros ajustáveis durante o processo e os parâmetros ajustados ou definidos antes do processo. A conformidade destes parâmetros conduz ao perfeito processo de soldagem.

Para fabricação do eixo, as principais variáveis do processo são: tensão do arco $22 \mathrm{~V}$, corrente elétrica 235A, velocidade de soldagem de $9 \mathrm{~mm} / \mathrm{seg}$, comprimento de arame energizado de $12 \mathrm{~mm}$, velocidade de alimentação do arame de 6,5 m/min, vazão de gás de 14 1/min (88\%Ar e $12 \% \mathrm{CO}_{2}$ ) e arame de diâmetro 1,2mm especificação AWS ER-70 S-3. 
Para provocar variações dimensionais e geométricas no cordão de solda do eixo, bem como possibilitar o aumento da incidência de defeitos, três parâmetros foram selecionados para serem variados, tensão do arco, corrente elétrica e velocidade de soldagem.

Desta forma, foram confeccionados dezoito eixos para testes de fadiga da seguinte forma: nove eixos com parâmetros de tensão de arco $22 \mathrm{~V}$, corrente elétrica $235 \mathrm{~A}$ e velocidade de soldagem de $9 \mathrm{~mm} / \mathrm{seg}$ (velocidade de alimentação de $6,5 \mathrm{~m} / \mathrm{min}$ ) e mais nove eixos com tensão do arco $29 \mathrm{~V}$, corrente elétrica $302 \mathrm{~A}$ e velocidade de soldagem de $15 \mathrm{~mm} / \mathrm{seg}$ (velocidade de alimentação de $10 \mathrm{~m} / \mathrm{min}$ ), conforme Tabela 5.3. Os demais parâmetros permaneceram constantes.

Tabela 5.3 - Variáveis adotadas para avaliação experimental

\begin{tabular}{|c|c|c|c|}
\hline & Tensão (V) & Corrente (A) & Velocidade (mm/seg) \\
\hline Versão A & 22 & 235 & 9 \\
\hline Versão B & 29 & 302 & 15 \\
\hline
\end{tabular}

A região de análise possui uma junta soldada sobreposta, a técnica empregada para execução da soldagem é puxando o cordão de solda, que se encontra em posição plana, com uma inclinação da pistola de aproximadamente $15^{\circ}$.

O mecanismo de transferência metálica ocorre por curto-circuito para ambas as versões de parâmetros de soldagem. Embora a corrente utilizada na versão "B" tenha sido 302A, o mecanismo de transferência metálica permaneceu em curto-circuito.

A quantidade de energia emprega na soldagem foi praticamente a mesma nas duas versões do processo. O objetivo foi não alterar o calor gerado durante a soldagem para que as propriedades metalúrgicas do metal de base, zona afetada pelo calor e metal de solda se mantivessem praticamente as mesmas. Desta forma foi reduzido drasticamente e influência do fator microestrutural na vida à fadiga dos eixos.

\subsection{Equipamentos}

\subsubsection{Dispositivo de Soldagem}

Para posicionamento e fixação das peças foi utilizado o dispositivo mostrado na Figura 5.2. 


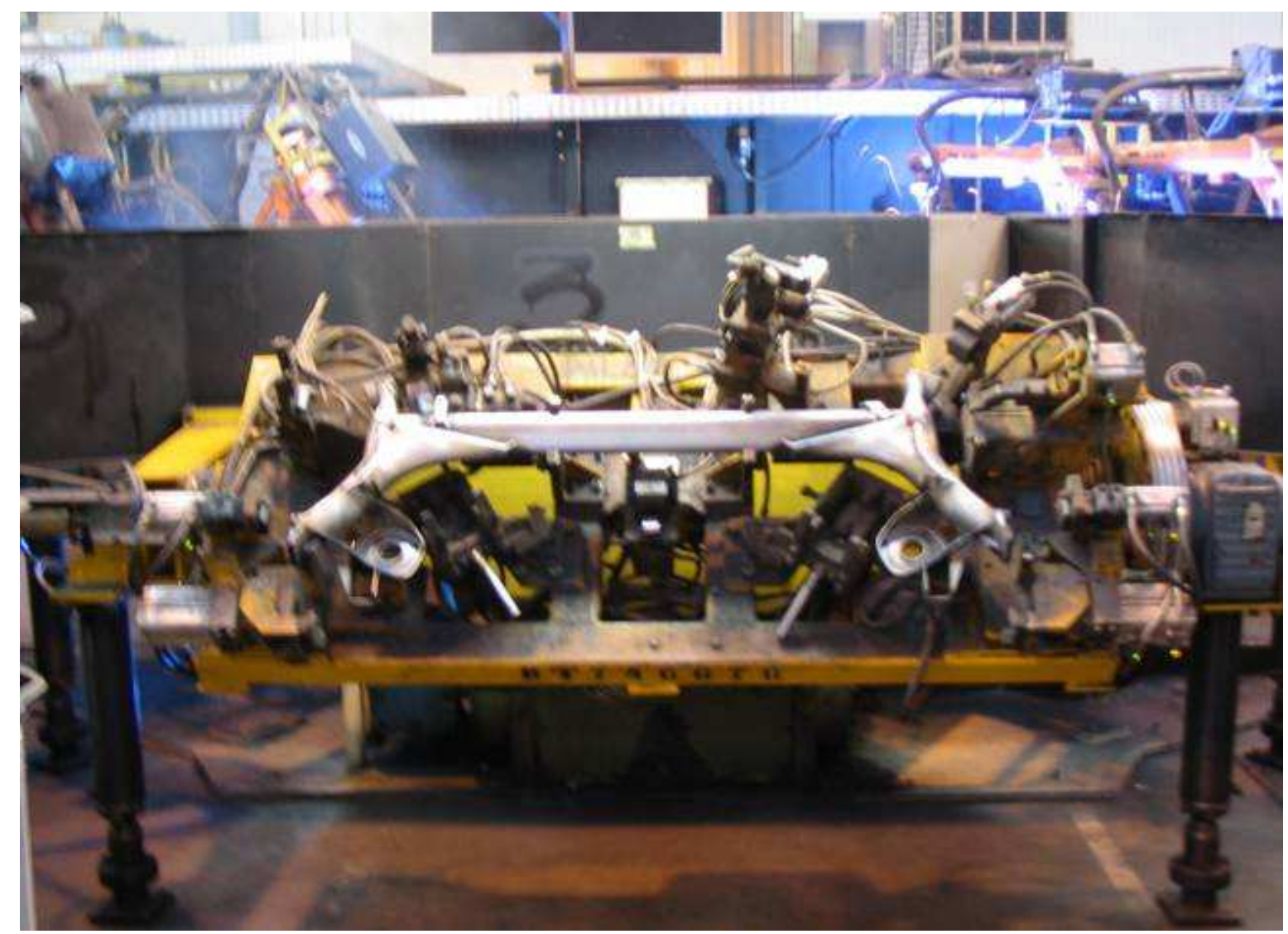

Figura 5.2 - Dispositivo de soldagem robotizado dos eixos

O dispositivo garante o posicionamento correto de um componente em relação ao componente adjacente através de sensores, de forma que a variação dimensional face a face entre flanges não supere $2 \mathrm{~mm}$. Os componentes são fixados por meio de garras e prisioneiros pneumáticos.

O equipamento de solda é um Fronius Trans Plus Sinergic 5000 (TPS 5000 R); suprido com uma unidade de controle com software versão 0164 e dois robôs ABB 2370 M94A.

\subsubsection{Dispositivo de testes}

Embora o eixo em questão tenha sido avaliado por diversos métodos como, método de elementos finitos e ensaios de durabilidade veicular, neste trabalho será reportado o resultado experimental obtido em teste em banco de provas em carregamento de torção do eixo em amplitude constante. As extremidades do braço longitudinal do lado direito e esquerdo são deslocadas alternadamente, para frente e para trás, de modo que a viga central do eixo fique sobre solicitação de torção. 
O equipamento de teste, mostrado na Figura 5.3 corresponde a um dispositivo eletro-magnético monitorado por uma unidade de controle de deslocamento e frequiência e programa Sysmag.

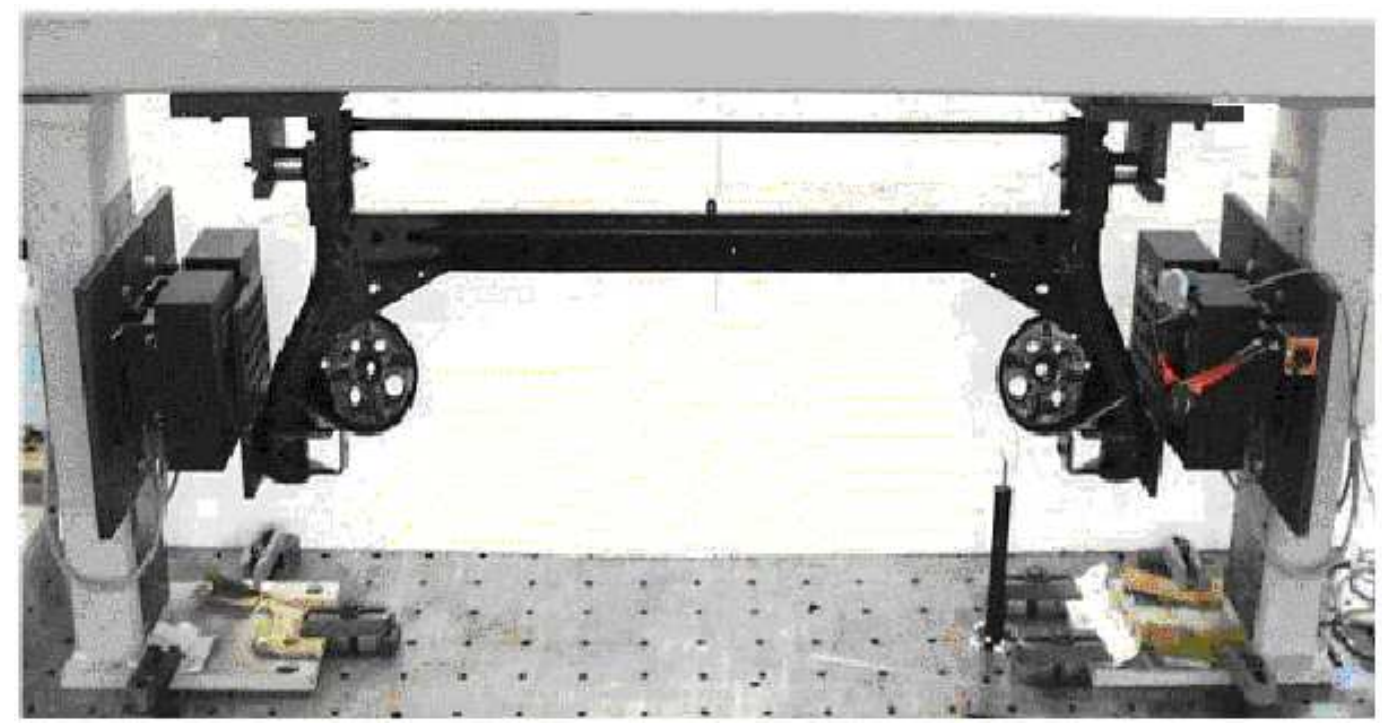

Figura 5.3 - Dispositivo para ensaio de torção do eixo - www.sincotec.de acessado em 26.07.07.

Suas principais características são: frequiência de operação de 7 a $15 \mathrm{~Hz}$; deslocamento máximo das extremidades do braço longitudinal +/- 50mm; peso aproximado $1.800 \mathrm{~kg}$; dimensões [mm]: $2000 \times 1500 \times 1000$.

\subsubsection{Equipamentos de análise do cordão}

Antes de iniciar o processo de análise dimensional, os eixos foram cortados com disco abrasivo nas regiões indicadas na Figura 5.4 e as superfícies de análise lixadas, polidas e atacadas quimicamente com solução Nital 2,5\%.

Após ataque as amostras foram secadas em estufa, a imagem das superfícies foi capturada por um estéreo-microscópio 6,7 x 37X e exportadas para o software Image-Pró Express, mostrado na Figura 5.5. 

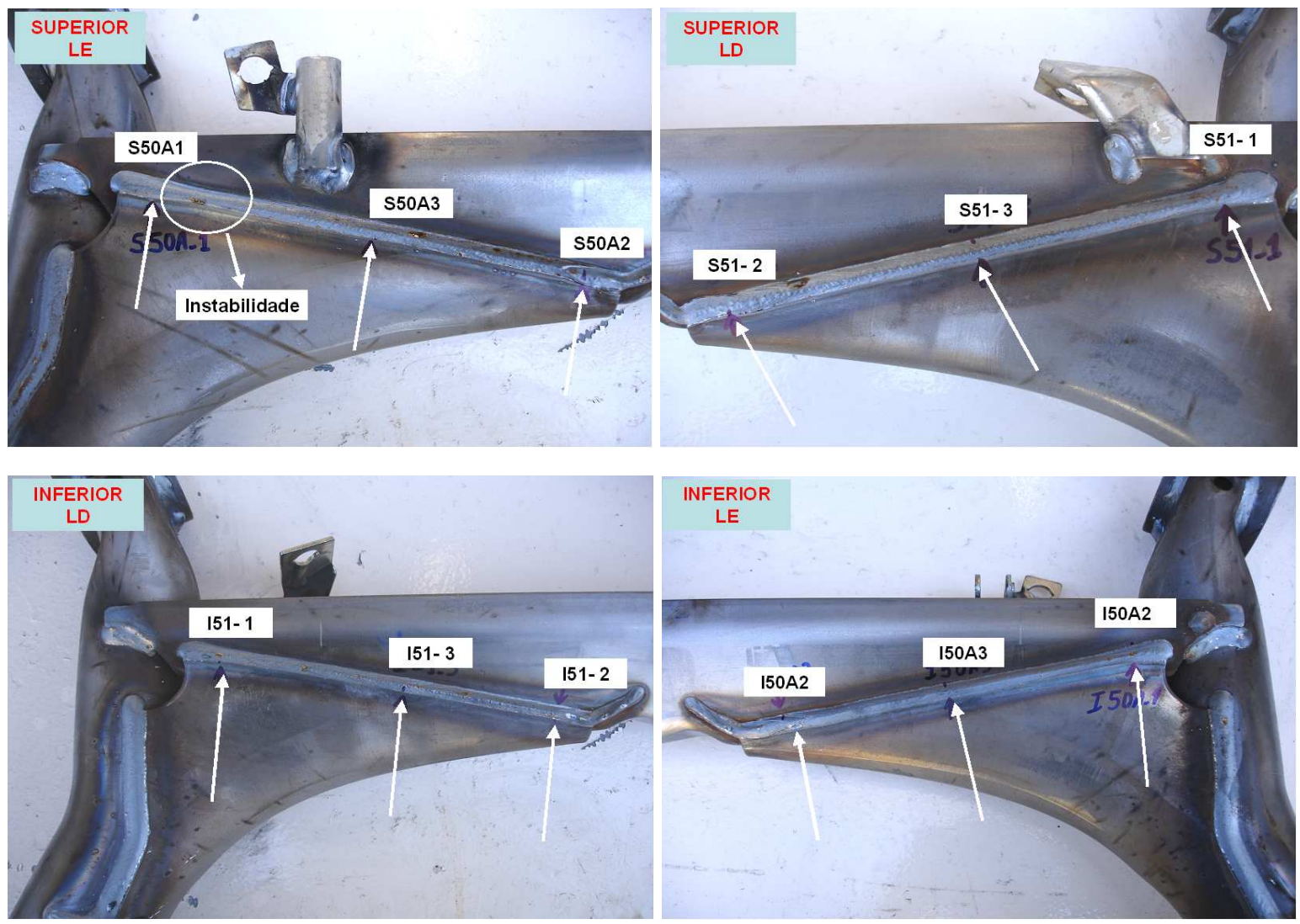

Figura 5.4 - Indicação das posições de corte do eixo para análise do cordão

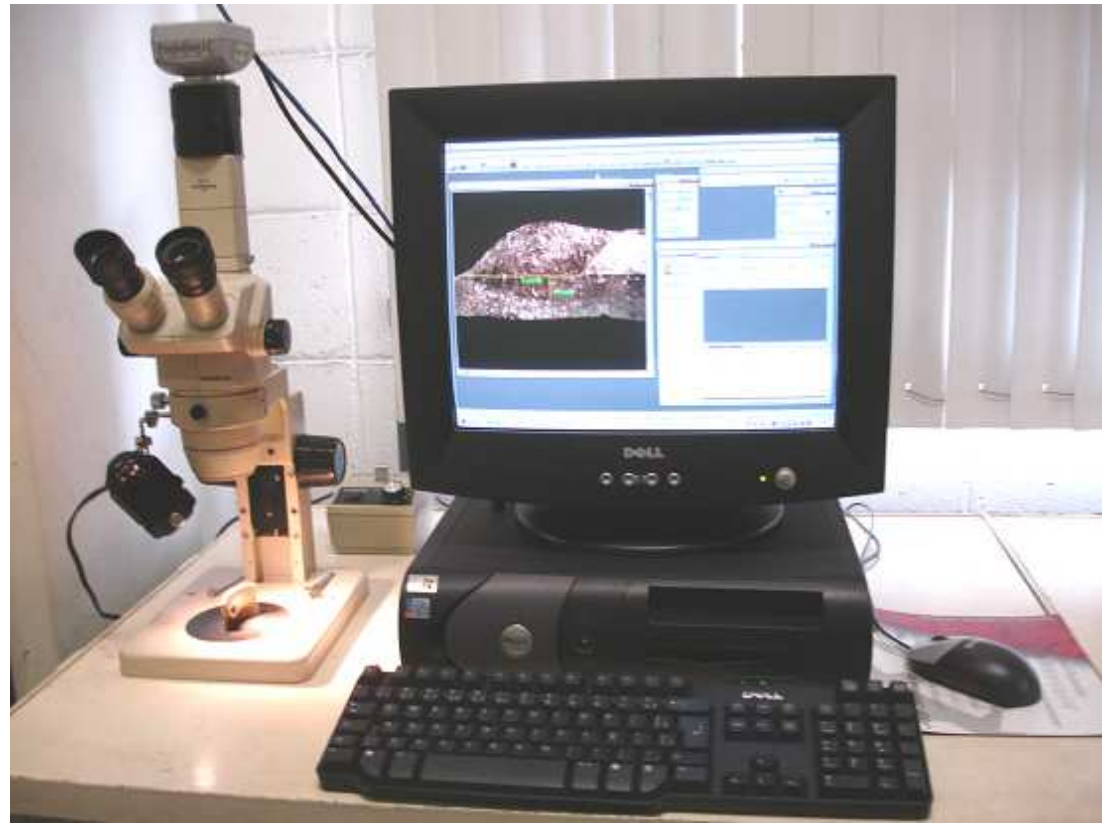

Figura 5.5 - Equipamento de medição do cordão de solda 


\subsection{Procedimento de teste}

Após serem confeccionados, os eixos foram submetidos ao ensaio de torção para obtenção da curva de deslocamento por número de ciclos para dois níveis distintos de deformação, controlado através do deslocamento de +/-30mm e +/-40mm em cada flange na extremidade do braço longitudinal do eixo, através de um campo magnético gerado pelo dispositivo mostrado na Figura 5.3,. Aplicando a equação 1 b do capítulo 2, o equipamento é automaticamente desligado quando há uma variação na freqüência natural do eixo de $0,20 \mathrm{~Hz}$, o que caracteriza haver potencialmente trinca(s) no mesmo. Para o ensaio de torção do eixo a trinca ocorre normalmente na região com concentração de tensão mecânica, conforme indicado na Figura 5.6. As análises de elementos finitos indicam que está região possui máxima tensão de tração, conforme mostrado na Figura 5.7, na qual se encontra em torno de 1/3 do valor de tensão de escoamento do metal de base com menor resistência mecânica.

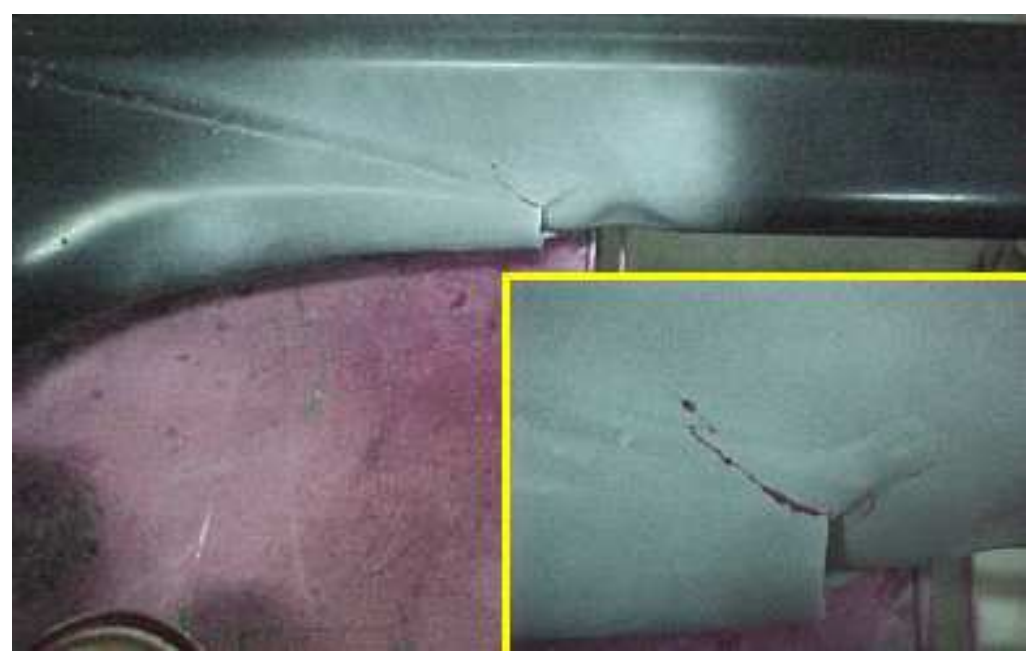

Figura 5.6 - Região de inicio da trinca. 


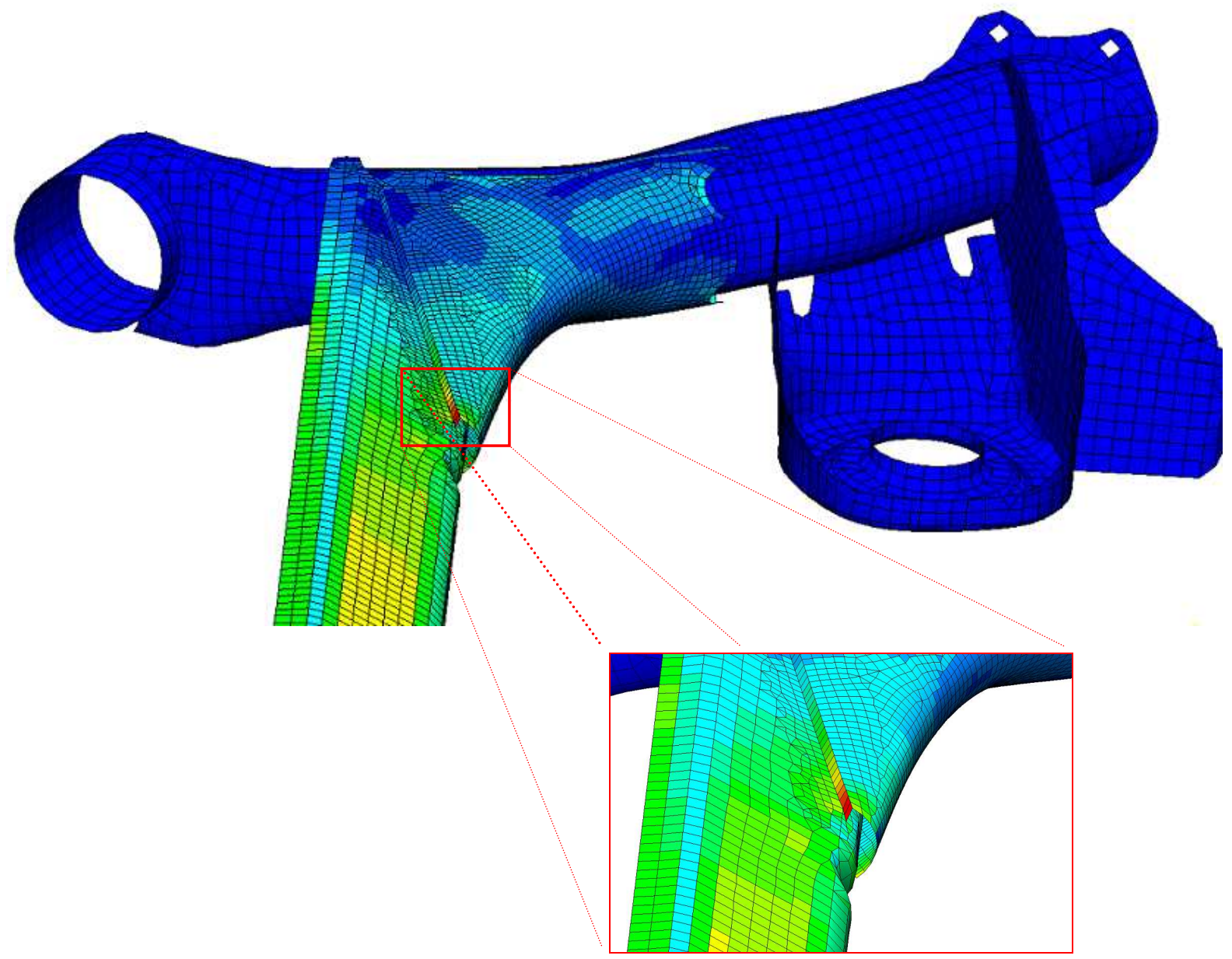

Figura 5.7 - Detalhe da região crítica de tensão revelado na análise de elementos finitos. 


\section{RESULTADOS}

O resultado dos testes de fadiga dos eixos, está apresentado graficamente através de uma curva simplificada de vida, para as duas versões de parâmetros de soldagem, ou seja, corrente, tensão e velocidade de soldagem "alta" e "baixa". As curvas correspondem à média aritmética da soma dos ciclos de vida de cada amostra (N50\%), para cada nível de carregamento, ou seja, +/-30mm e +/-40mm. Um total de oito eixos foram testados para cada amplitude de deformação e são apresentados na Figura 6.1.

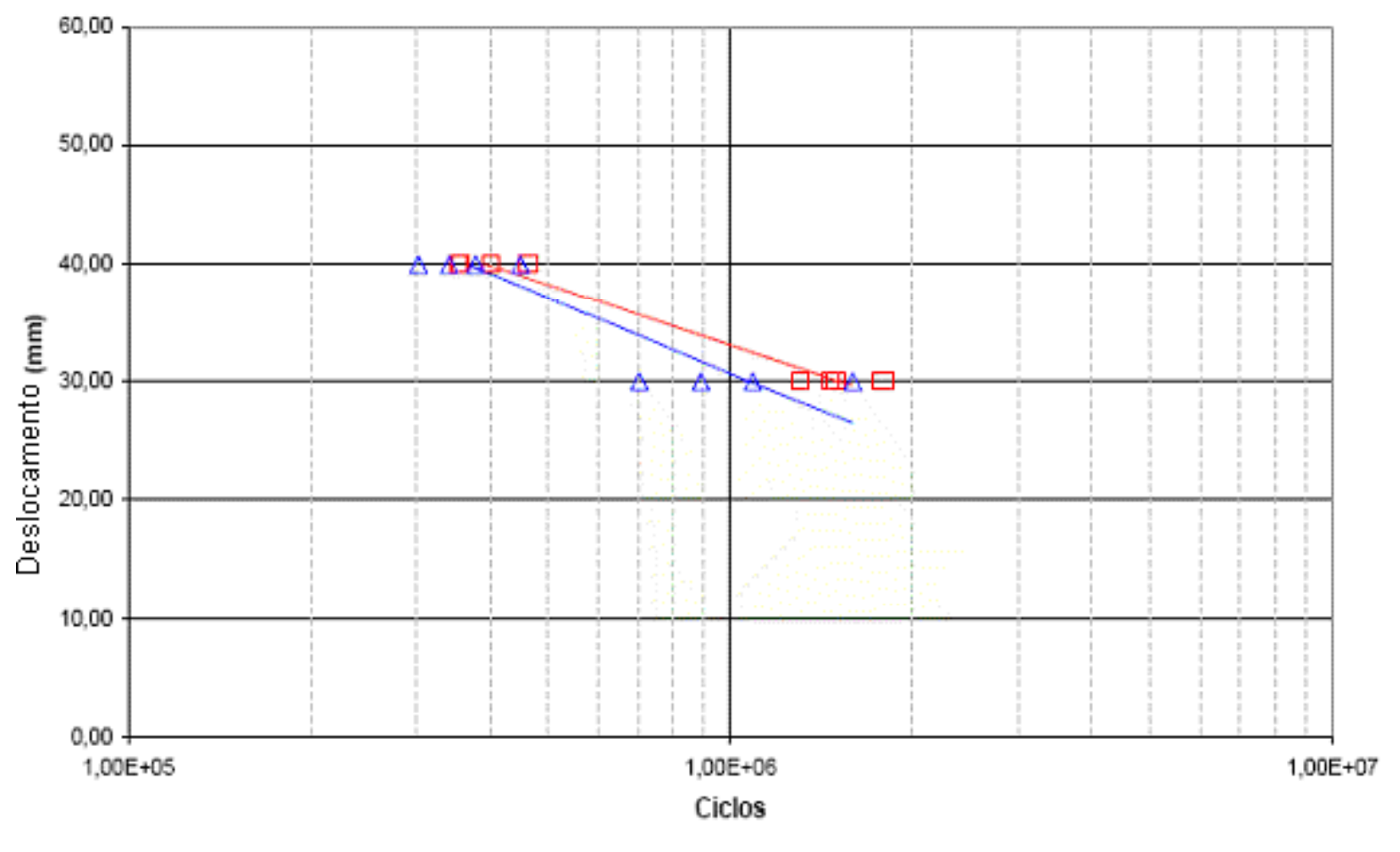

$\square 9 \mathrm{~mm} / \mathrm{seg} \quad \Delta 15 \mathrm{~mm} / \mathrm{seg}$

Figura 6.1 - Efeito da alteração dos parâmetros de soldagem na fadiga das juntas soldadas

Cada eixo foi então analisado quanto às variações geométricas no cordão de solda através do estéreo-microscópio 6,7 x 37X e do software Image-Pró Express, bem como submetidos às análises de micrografia e fractografia. Os resultados mostraram que houve alterações significativas na geometria do cordão de solda, bem como na incidência de defeitos, para a versão "B" de parâmetros de soldagem. 
Entretanto, nos exames realizados, não foram encontradas em nenhuma das amostras analisadas, inclusões e porosidade na superfície de fratura, inerentes ao processo de soldagem. A análise da fratura revelou que os eixos fraturaram por fadiga, para ambas condições de soldagem. Estas observações provam que a diferença de resistência à fadiga das duas versões de eixos deve ser atribuída aos fatores geométricos da solda.

\subsection{Fractografia}

Amostras para análise foram retiradas dos eixos após o término dos ensaios em seguida foram cortadas transversalmente ao cordão de solda, próximas ao término e início da trinca e a superfície da fratura foi revelada. Os espécimes foram analisados com microscópio eletrônico de varredura (MEV) Jeol JSM - 5800 LV. As regiões de iniciação da trinca e crescimento estável foram observadas, fotografadas e suas características são mostradas nas figuras que seguem.

A Figura 6.2, referente a uma amostra do processo de soldagem com velocidade de $15 \mathrm{~mm} / \mathrm{seg}$ (versão B), mostra uma região pouco oxidada e revela uma superfície de fratura por fadiga. A Figura 6.3 mostra uma região bastante oxidada, próxima ao final do cordão de solda, indicando que foi o local que ficou mais tempo exposto a oxidação e portanto local onde iniciou a trinca.

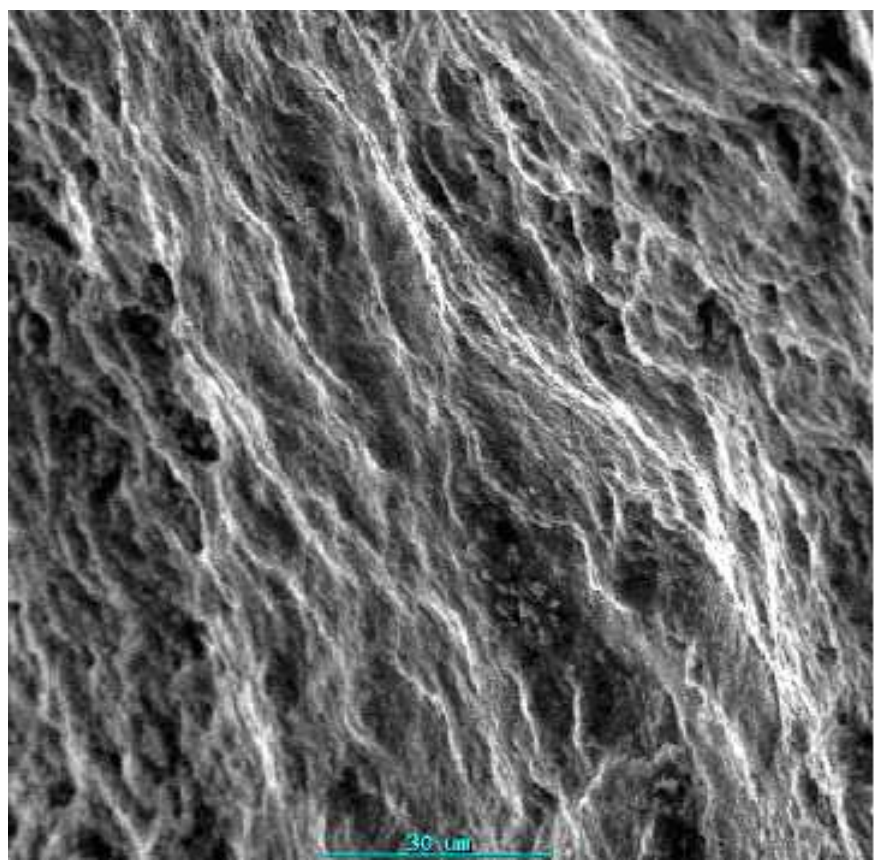

Figura 6.2 - Superfície de fratura de fadiga - MEV 

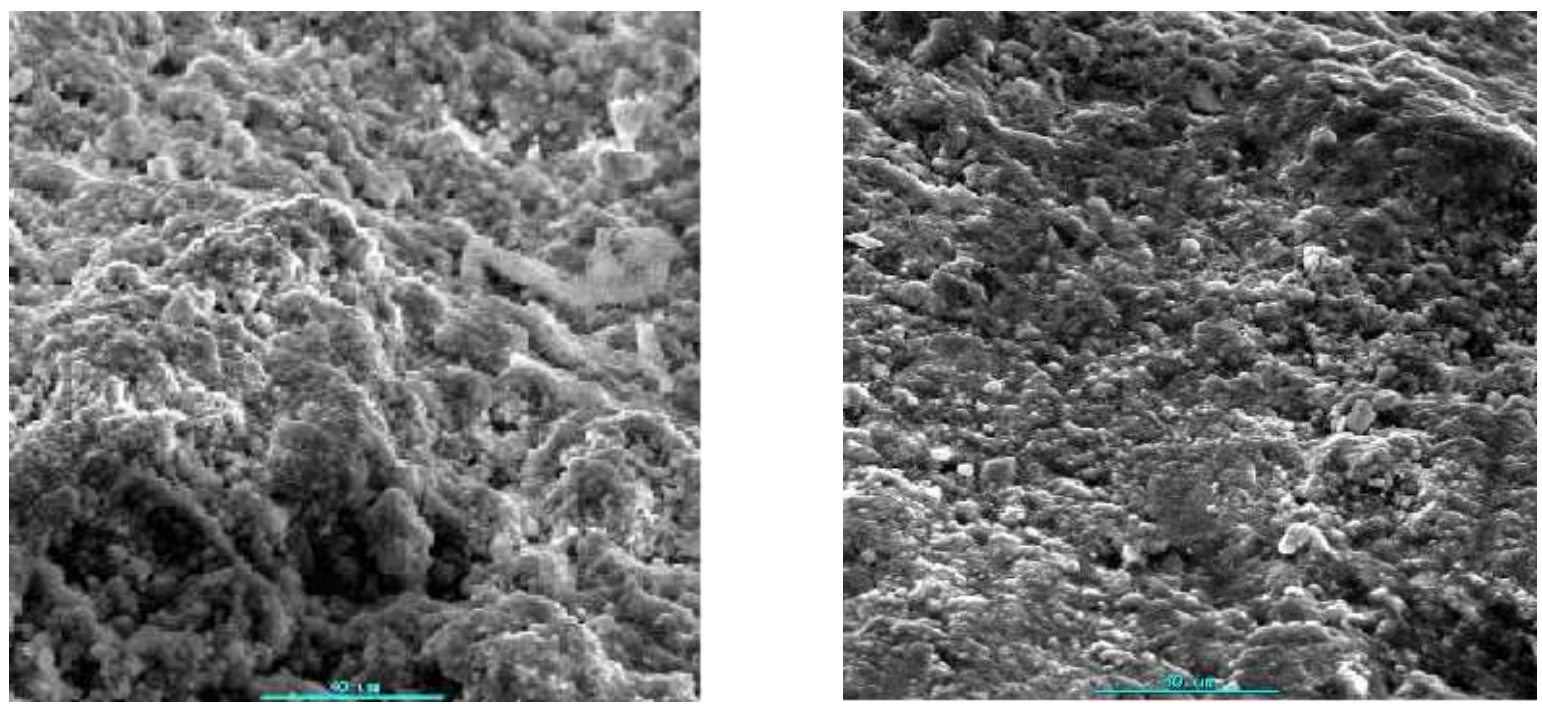

Figura 6.3 - Detalhe mostra a oxidação na superfície da fratura - MEV

A trinca nucleou-se em conseqüência da falta de fusão da solda no perfil de torção. Entretanto observa-se também que na região da secção $\mathrm{S} 1$, do mesmo cordão de solda, a penetração está normal, conforme mostrado na Figura 6.4.

Isto mostra que a falta de fusão pode estar associada ao aumento da velocidade de soldagem, gerando instabilidade do arco durante a soldagem. 


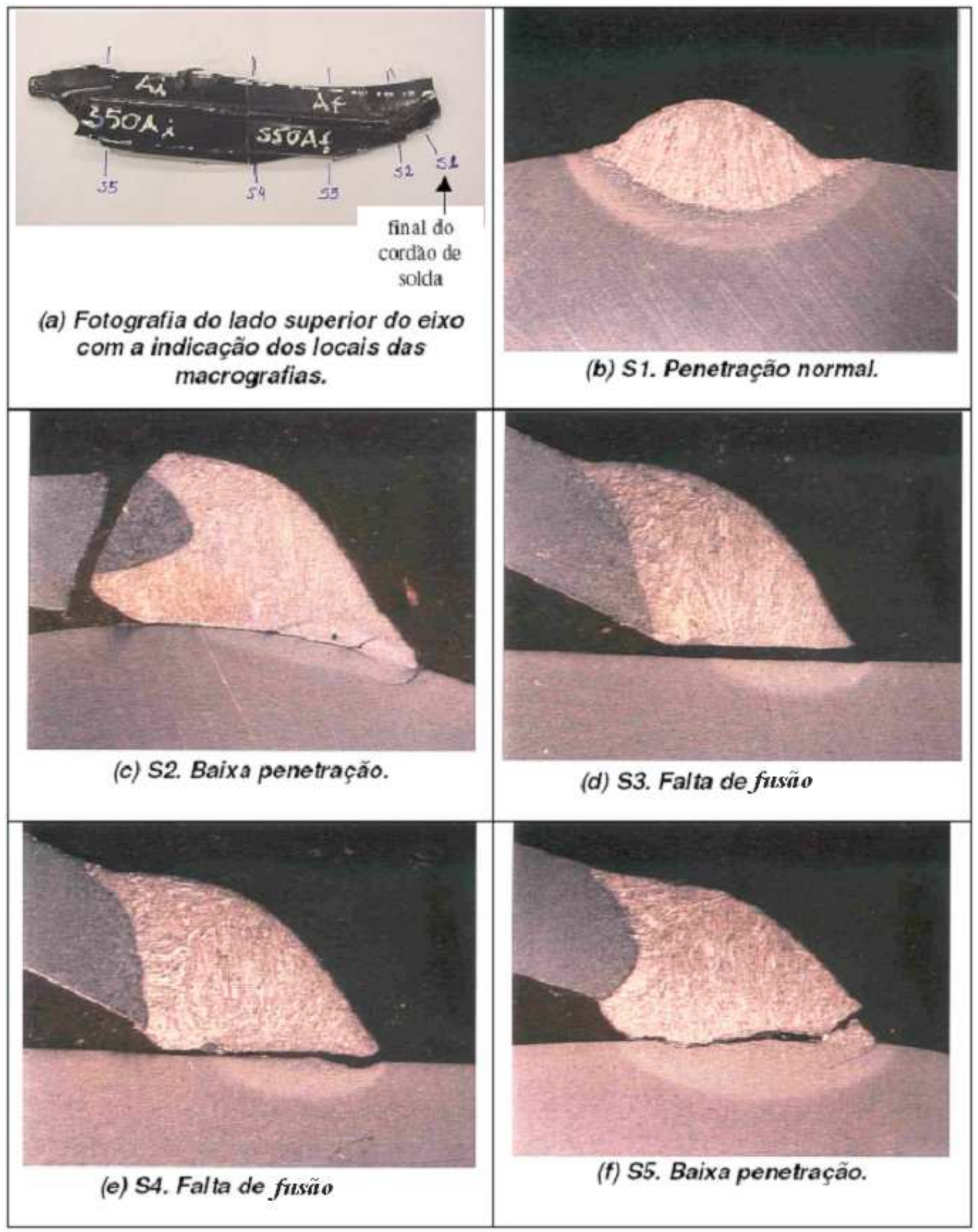

Figura 6.4 - Secções transversais do cordão de solda com falta de penetração. 
Como relatado, todos os eixos analisados fraturaram por fadiga, a Figura 6.5 mostra a superfície da fratura de uma amostra referente ao processo de soldagem com velocidade de $9 \mathrm{~mm} / \mathrm{seg}$ (versão A).

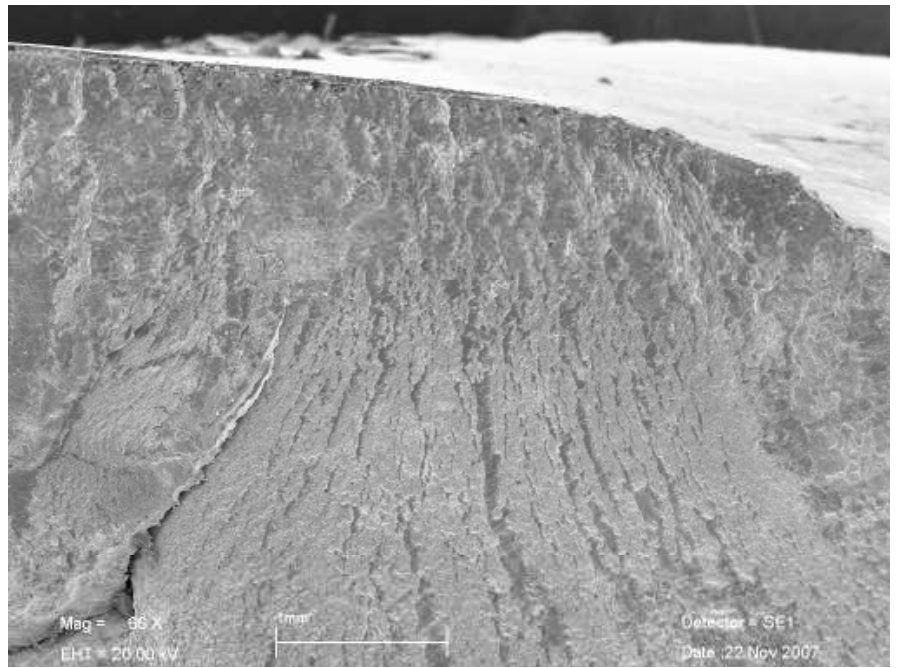

Figura 6.5 - Marcas de fratura típica de fadiga - MEV

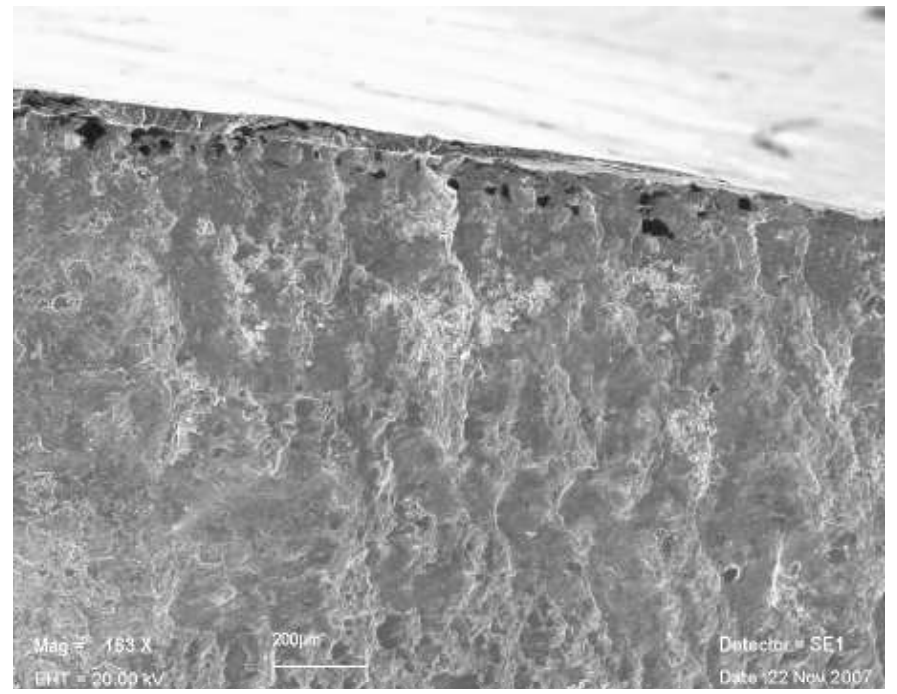

Figura 6.6 - Detalhe da superfície de fratura - MEV

Embora o modo de falha tenha sido os mesmos para todos os eixos, ou seja, as trincas iniciaram no final do cordão de solda, não se observou em nenhuma amostra, referente ao processo com 
velocidade de $9 \mathrm{~mm} / \mathrm{seg}$, falta de penetração do cordão de solda. A seta da Figura 6.7 indica a região do final do cordão de solda.

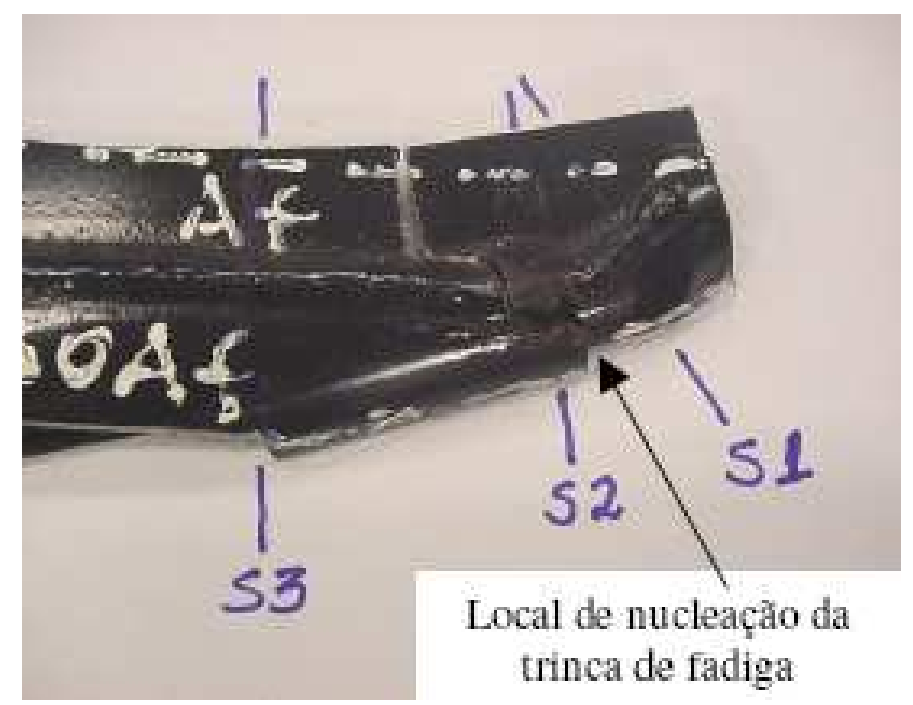

Figura 6.7 - Detalhe do local de iniciação da trinca.

O fato de todos os eixos terem falhado com trincas iniciadas em regiões próxima ao final do cordão de solda deve-se à concentração localizada de tensão mecânica próxima a região do término de cordão, mostrada na Figura 5.7.

\subsection{Análise metalográfica}

A análise executada através do exame metalográfico e da dureza Vickers na região crítica do cordão de solda, para ambas versões de parâmetros de soldagem, apresentou resultados compatíveis com a quantidade de energia empregada durante o processo de soldagem e taxa de resfriamento.

Fórmulas de carbono equivalente (CE) são comumente usadas para estimar a necessidade de cuidados especiais na soldagem de um aço. Uma expressão de CE muito utilizada é:

$$
C_{e q}=C+\frac{M n}{6}+\frac{S i}{24}+\frac{N i}{40}+\frac{C r}{5}+\frac{M o}{4}+\frac{V}{14}
$$


É ideal calcular o CE para a composição real do aço. Quando a composição real não é conhecida ou se torna inviável, deve-se utilizar os teores máximos na faixa de especificação do aço, Tabela 5.1.

Neste caso, os metais de base (escora e travessa) possuem carbono equivalente de $0,17 \%$ e 0,38\%, para a escora e travessa, respectivamente, calculado pela máxima da faixa de especificação. Estes valores são considerados adequados para as condições de soldabilidade.

A Figura $6.8 ; 6.9 ; 6.10$ mostram a características microestruturais da zona afetada pelo calor, metal de base e solda em secção transversal do cordão de solda.
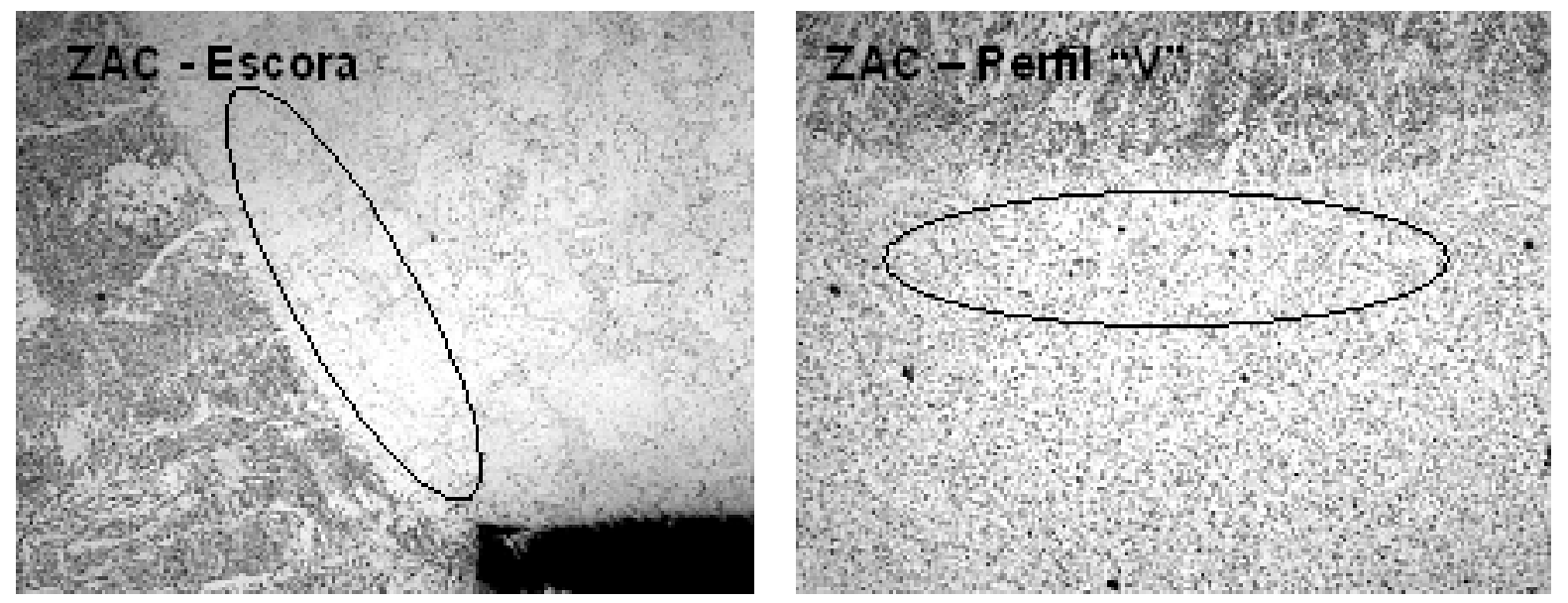

Figura 6.8 - Grão grosseiros de ferrita na escora. Ferrita acicular com traços de perlita na travessa "V".
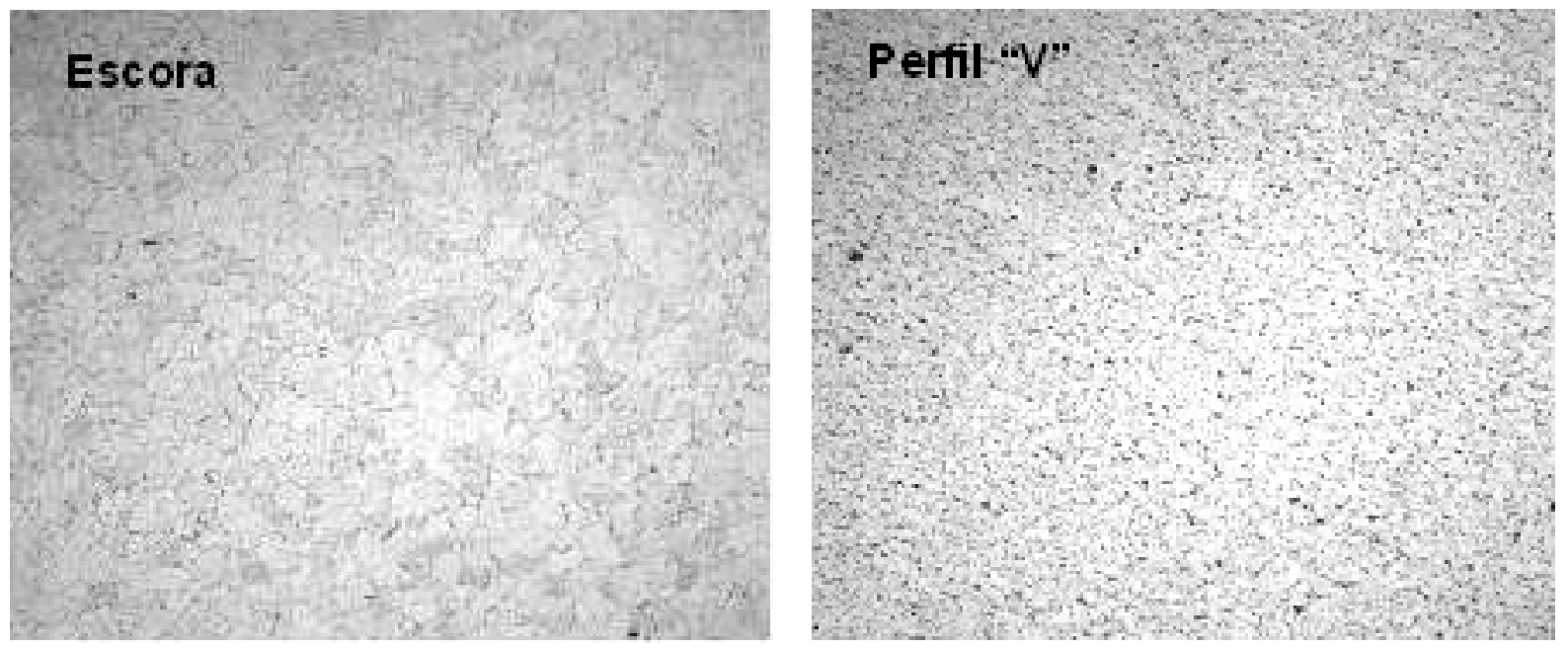

Figura 6.9 - Matriz de ferrita e traços de perlita na escora. Ferrita e traços de perlita de grão fino na travessa "V". 


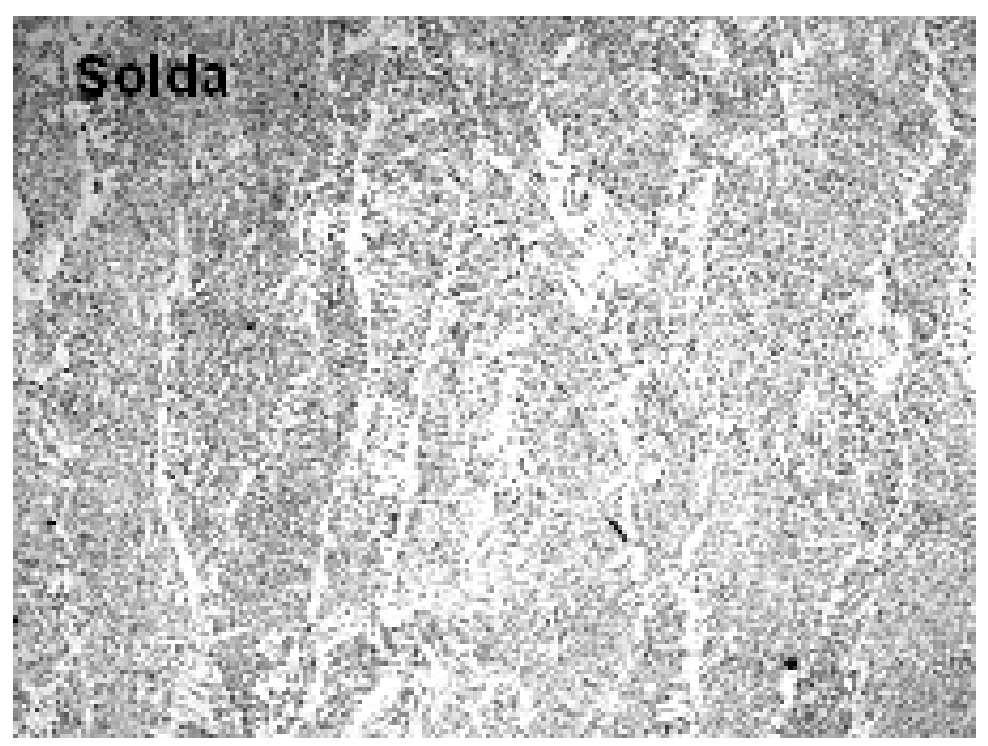

Figura 6.10 - Microestrutura de grãos colunares de ferrita acicular.

Embora os valores de carbono equivalente sejam considerados baixos, uma análise de dureza foi realizada. Esta análise e os valores dos limites de resistência à tração demonstram que não houve influência do aporte térmico sobre o desempenho à fadiga dos eixos. O aporte térmico, referente a este estudo, para ambas as condições de soldagem, possui valores bem parecidos. A região analisada, mostrada na Figura 6.11 é considerada crítica, conforme dados da análise de elementos finitos e confirmações obtidas no ensaio de torção do eixo através da iniciação da trinca nesta região. Os resultados das propriedades mecânicas estão mostrados na Tabela 6.1.

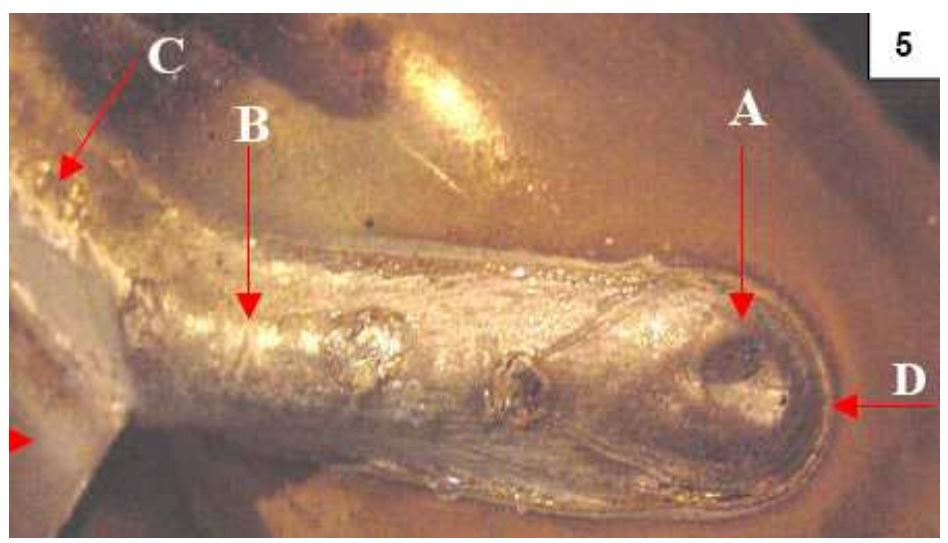

Figura 6.11 - Detalhe da região onde foi medida a dureza 


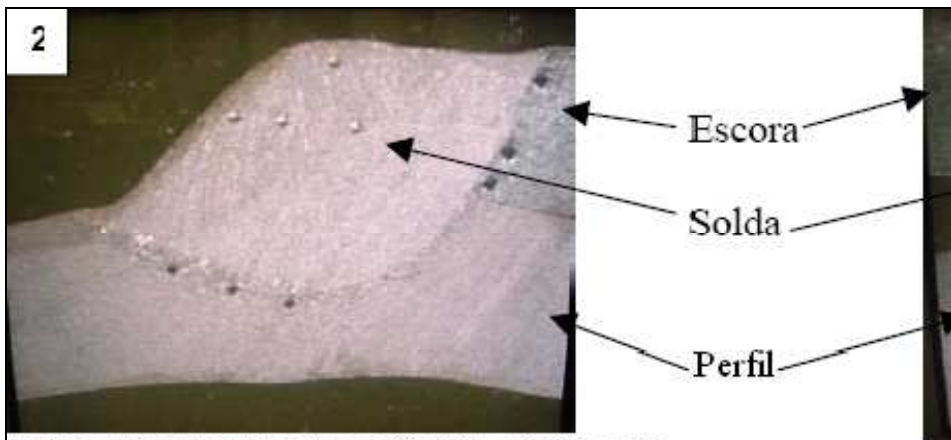

Solda dir.superior (posição C) - Solda com boa fusão.

Solda esq.superior (posição C) -solda com boa fusão.

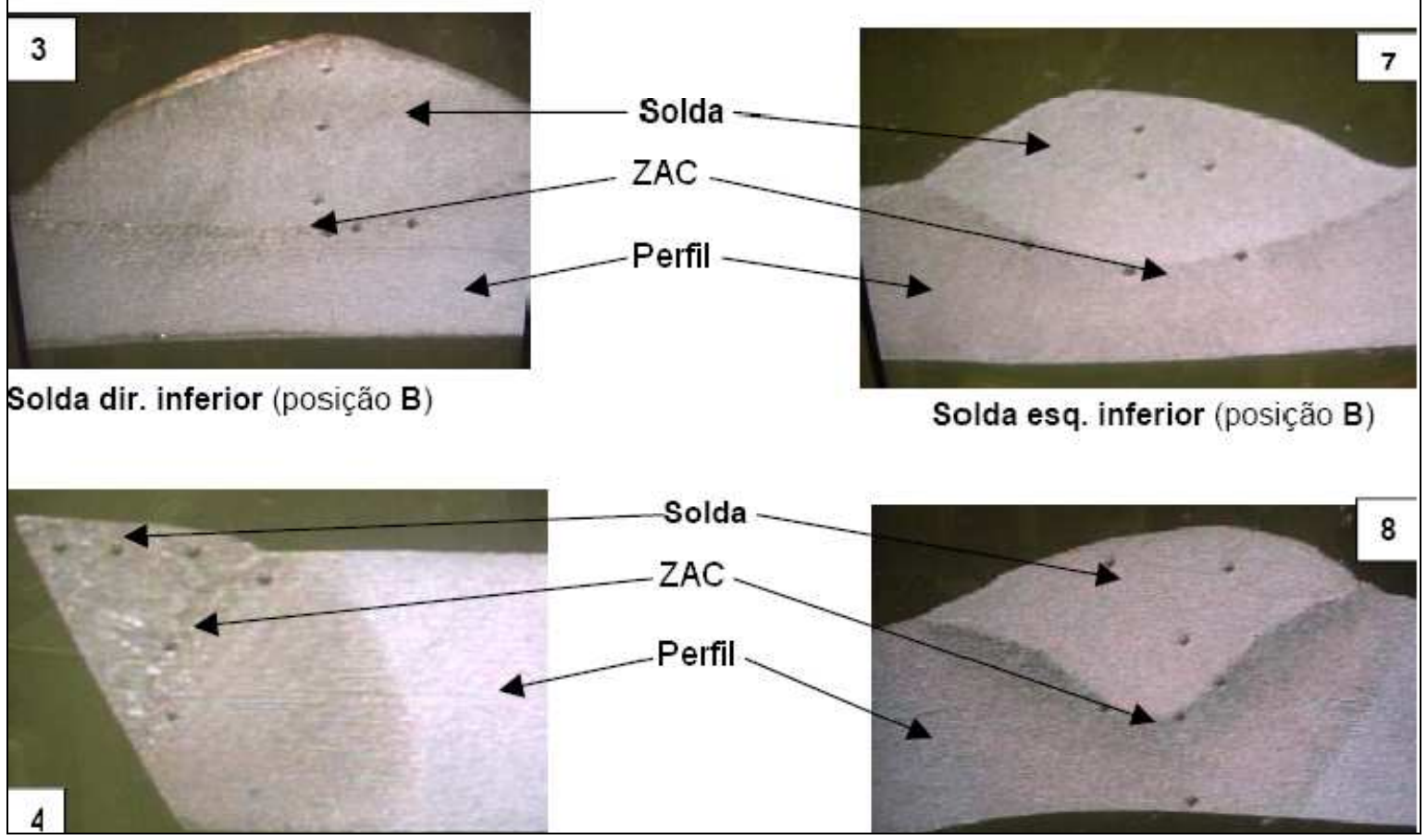

Figura 6.12 - Seções transversais da região onde foi medida a dureza 


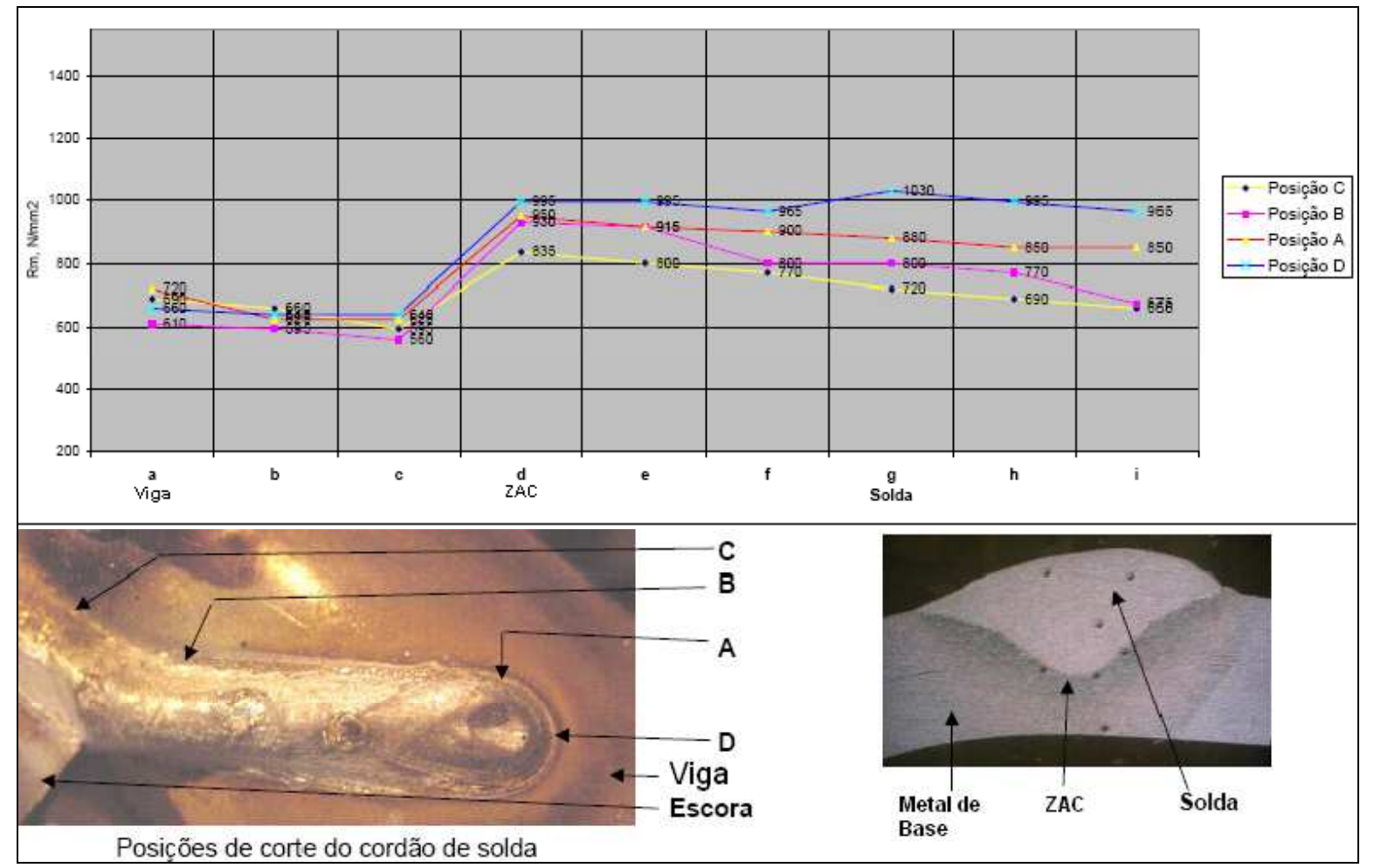

Figura 6.13 - Resumo dos resultados de medição da dureza Vickers

Tabela 6.1 - Propriedades mecânicas do cordão e adjacências - medição através de HV10

\begin{tabular}{|c|c|c|c|c|c|c|c|c|c|c|}
\hline \multirow{3}{*}{$\begin{array}{l}\text { Pontos medição } \\
\text { conforme croquis } \\
\text { ao lado }\end{array}$} & \multicolumn{3}{|c|}{ Perfil } & \multicolumn{3}{|c|}{ ZAC } & \multicolumn{3}{|c|}{ Solda } & \multirow[t]{2}{*}{ Perfil } \\
\hline & $a$ & $\mathrm{~b}$ & c & d & $\mathrm{e}$ & $f$ & $\mathrm{~g}$ & $\mathrm{~h}$ & $\mathrm{i}$ & \\
\hline & \multicolumn{9}{|c|}{$\mathrm{Rm}, \mathrm{N} / \mathrm{mm} 2$} & \\
\hline Posição C - foto 2 & 690 & 660 & 595 & 835 & 800 & 770 & 720 & 690 & 660 & \\
\hline Posição B - foto 3 & 610 & 595 & 560 & 930 & 915 & 800 & 800 & 770 & 675 & \\
\hline Posição $\mathrm{A}$ - foto 8 & 720 & 625 & 625 & 950 & 915 & 900 & 880 & 850 & 850 & \\
\hline \multirow[t]{2}{*}{ Posição $\mathrm{D}$ - foto 4} & 660 & 640 & 640 & 995 & 995 & 965 & 1030 & 995 & 965 & \\
\hline & \multicolumn{3}{|c|}{ Escora } & & & & & & & \\
\hline $\mathrm{Rm}$ & 335 & 320 & 305 & 495 & 450 & 415 & 720 & 690 & 660 & \\
\hline
\end{tabular}

\subsection{Considerações finais}

Os defeitos ocorridos durante a soldagem do eixo traseiro são tratados na bibliografia corrente e nas normas padrões como os principais responsáveis para a diminuição da vida em fadiga de juntas soldadas [40][42][52][56].

Os principais defeitos encontrados no cordão de solda dos eixos analisados por macrografia estão representados na Tabela 6.2. A referência mostra a comparação entre a entre a penetração da solda para as duas versões de parâmetros de soldagem estabelecidos. 
Tabela 6.2 - Incidência de defeitos nos cordões de solda

\begin{tabular}{|c|c|c|c|c|c|}
\cline { 2 - 6 } \multicolumn{1}{l|}{} & $\begin{array}{c}\text { Baixa Penetração } \\
<25 \%\end{array}$ & Mordedura & Porosidade & $\begin{array}{c}\text { Reforço Excessivo } \\
>4 \mathrm{~mm}\end{array}$ & $\begin{array}{c}\text { Cordão estreito } \\
<8 \mathrm{~mm}\end{array}$ \\
\hline $\begin{array}{c}22 \text { Volts } \\
235 \text { Âmperes } \\
9 \mathrm{~mm} / \mathrm{seg}\end{array}$ & 0 & 1 & 0 & 0 & 1 \\
\hline $\begin{array}{c}29 \text { Volts } \\
302 \text { Âmperes } \\
15 \mathrm{~mm} / \mathrm{seg}\end{array}$ & 4 & 4 & 0 & 0 & 4 \\
\hline
\end{tabular}

Nota-se que a variação dos parâmetros de soldagem teve maior influência na penetração do cordão, seguido pela mordedura e estreitamento do cordão. Neste último, a corrente mais alta poderia conduzir a um aumento na largura do cordão, entretanto o que se observou foi o contrário. Isto pode ter explicação no fato de não ter havido aumento significante na energia empregada, daí a velocidade mais alta foi determinante para menores larguras de cordão.

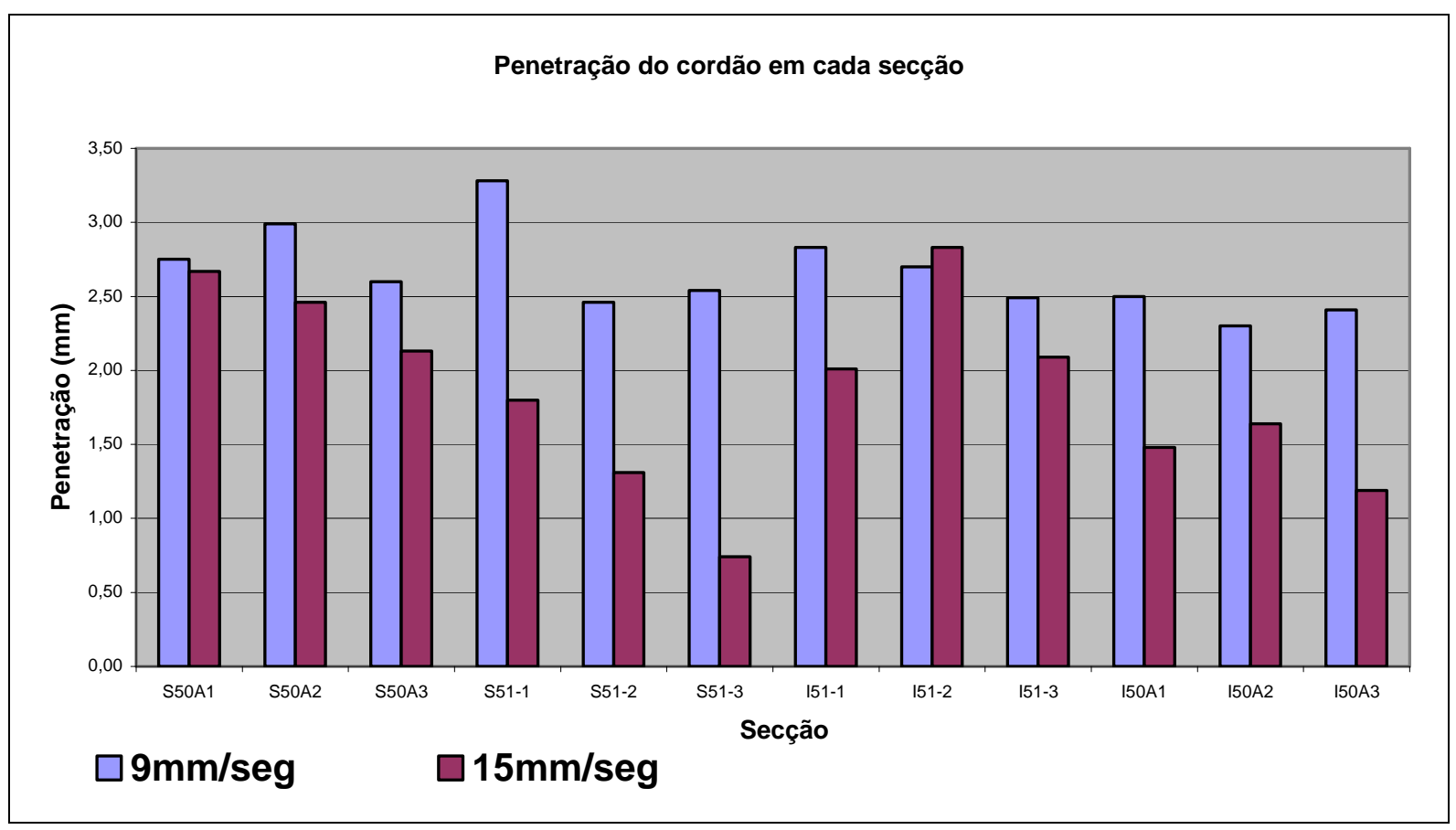

Figura 6.14 - Variação da penetração ao longo do cordão para cada versão de eixo 
Os testes de fadiga apontam que os defeitos geométricos, como falta de penetração e mordedura, foram prejudiciais na integridade da junta soldada. As trincas iniciaram na região de maior tensão mecânica, porém, na presença destes defeitos, a vida à fadiga foi abreviada. A Figura 6.15 mostra um típico defeito na extremidade do cordão e a trinca iniciada neste defeito após solicitações mecânicas do eixo.
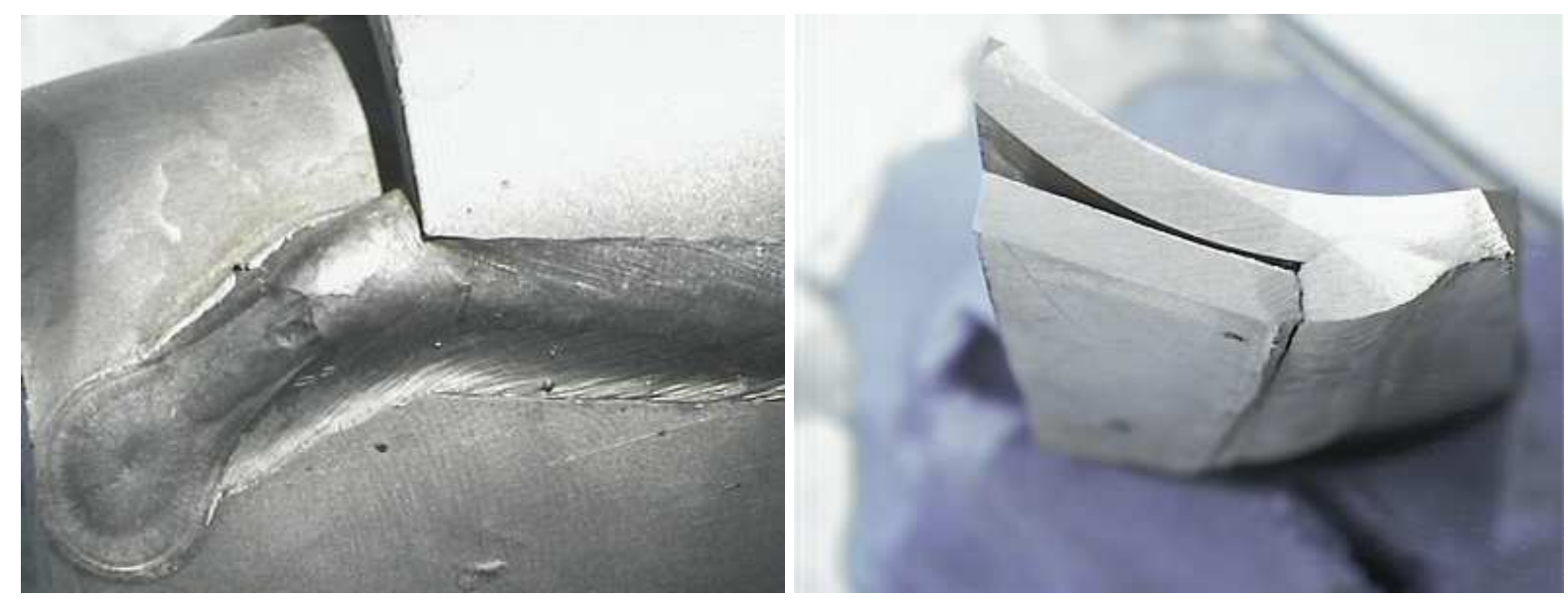

Figura 6.15 - Defeito da solda e trinca de fadiga

O ensaio de torção do eixo também apontou que a abertura da junta soldada, ou seja, distância entre os componentes soldados, influenciou também na integridade da junta. Em um eixo soldado, onde a abertura da junta apresentava dimensão maior que $1 \mathrm{~mm}$, a trinca de fadiga iniciou nesta região, coincidentemente próximo a região do final do cordão e por isto, este foi o eixo que falhou com o menor número de ciclos. A Figura 6.16 mostra a abertura da junta soldada.
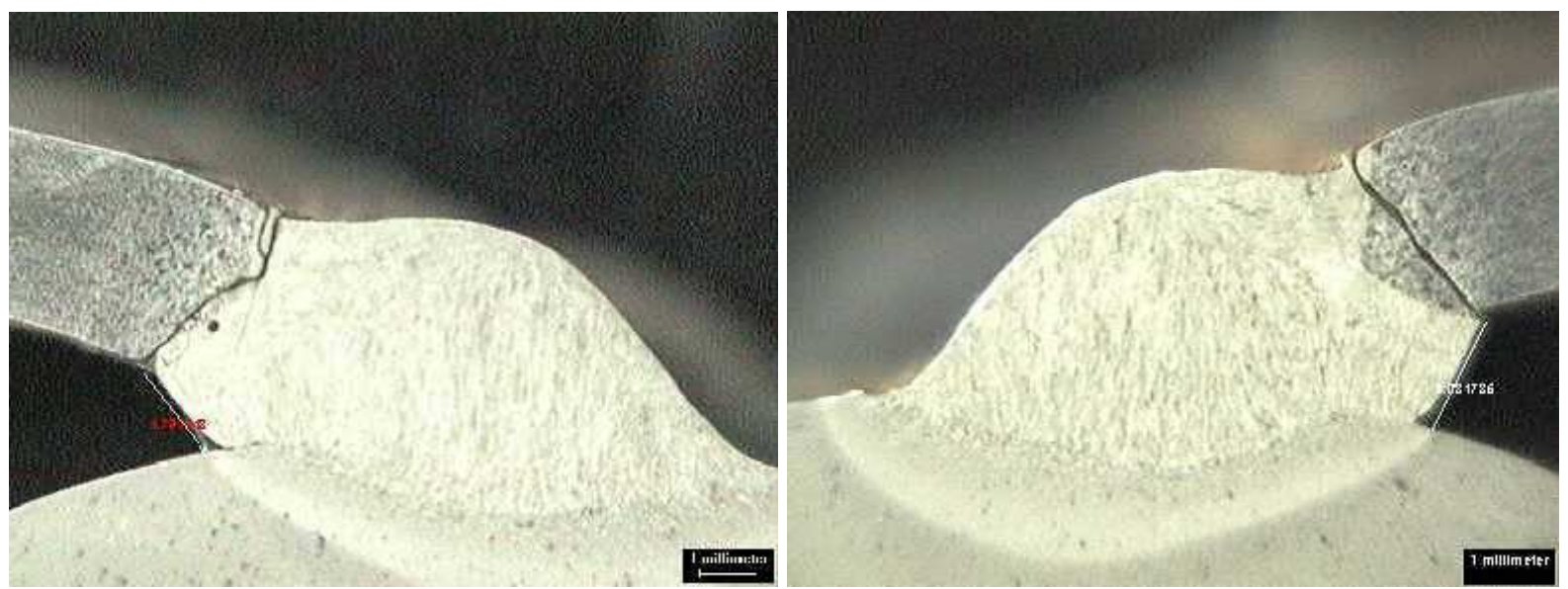
Figura 6.16 - Trincas na região de maior abertura da junta

Algumas das secções analisadas nos ensaios de metalografia, dimensional e medição de dureza estão mostrados na Figura 6.17 e Figura 6.18, para os parâmetros de soldagem "A" (velocidade de 9mm/seg) e parâmetros "B" (velocidade de $15 \mathrm{~mm} / \mathrm{seg}$ ).

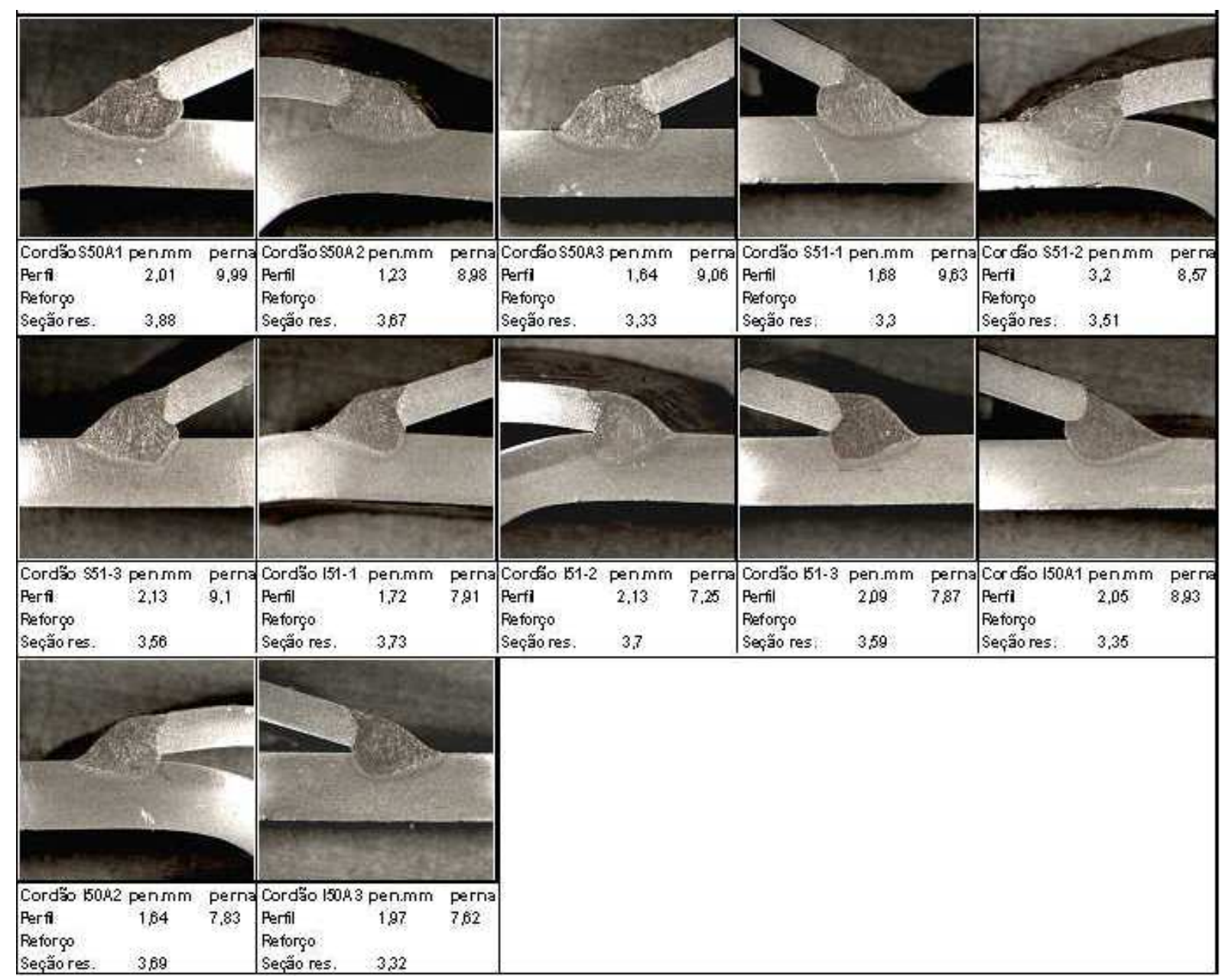

Figura 6.17 - Seções do cordão de solda pelo processo 9mm/seg (versão “A”) 


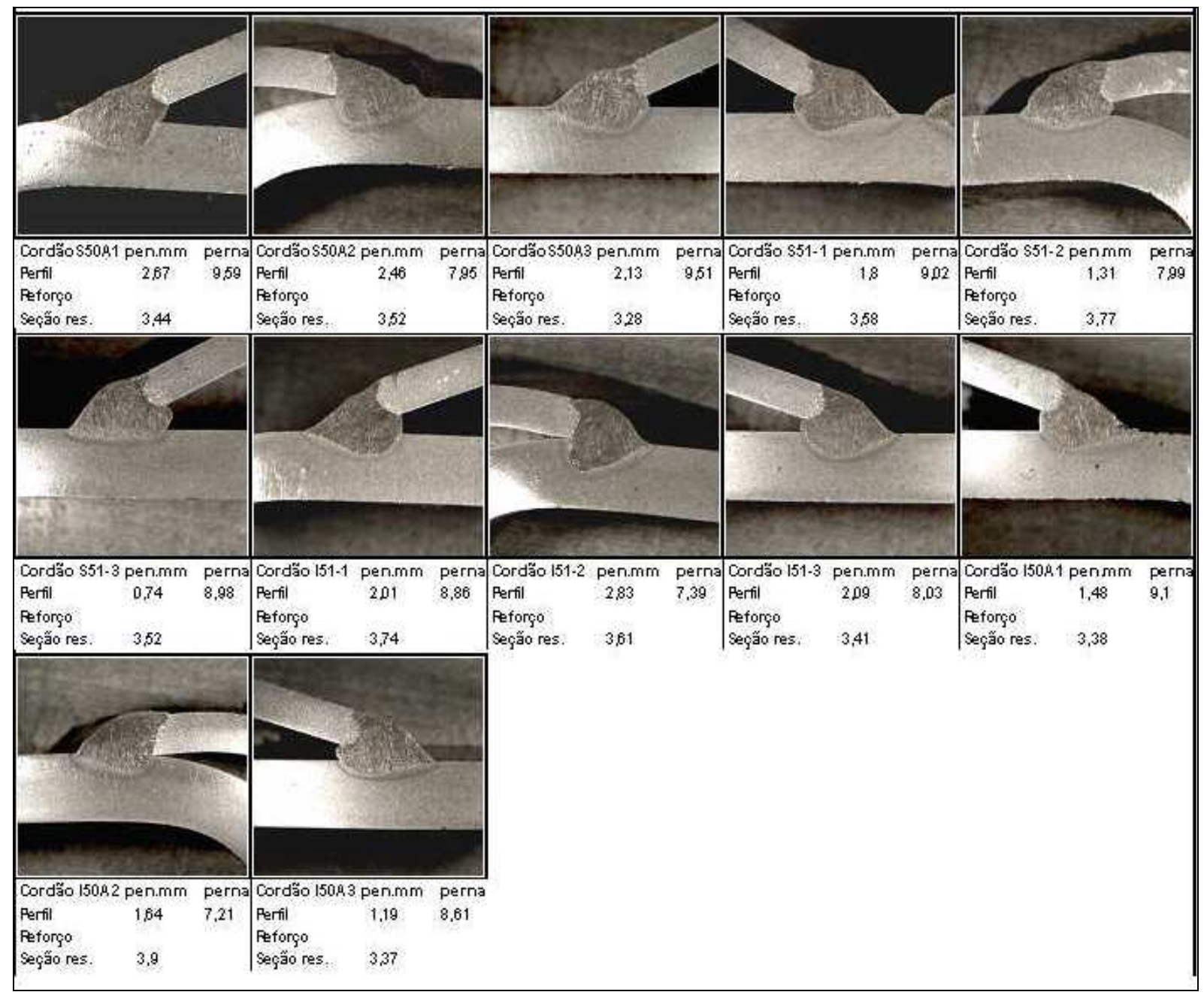

Figura 6.18 - Seções do cordão de solda pelo processo 15mm/seg (versão "B”) 


\section{CONCLUSÕES}

O objetivo principal deste trabalho é avaliar o quanto alterações nos parâmetros de soldagem afetam no surgimento de defeitos no cordão e este, por sua vez, afeta a vida a fadiga de um eixo traseiro interdependente veicular.

É sabido que, por projeto, eixos traseiros interdependentes possuem tensões críticas nos seus cordões de solda [2], no entanto, devido ao seu baixo custo de fabricação e fácil instalação, é o preferido para equipar veículos de passeio de pequeno e médio porte.

A demanda crescente por produtividade nos leva a tomada de decisões rápidas, às vezes pouco pensadas. Na fabricação de componentes soldados, com longa duração de processo, a pressão vem para reduzir o tempo de ciclo por peça fabricada e, quase sempre, sugerimos o aumento da velocidade de soldagem. Este parâmetro vem acompanhado de ajustes nos demais parâmetros primários, ou seja, corrente elétrica e tensão do arco, visando manter a estabilidade do arco voltaico [16].

À luz dos resultados aqui apresentados, observa-se com o aumento da velocidade levou a uma redução na profundidade de penetração da solda. Embora tenha havido ajustes na corrente (I) e na tensão $(V)$, este resultado diverge da literatura [19][22]. Entretanto na pesquisa realizada por Karadeniz [59], os parâmetros primários foram variados um de cada vez, demonstrando que existe um valor "ótimo" de velocidade, corrente e tensão que propiciam uma maior profundidade de penetração, porém, a tendência da curva de penetração versus velocidade de soldagem é decrescente para valores muito alto de velocidade.

O aumento da velocidade gerou uma diminuição na largura do cordão em toda sua extensão. Observa-se, portanto, que não houve redução significativa na altura do reforço do cordão, gerando assim cordão de solda estreito e alto. Esta característica do perfil geométrico da solda conduz a menores raios de curvatura na margem da solda, aumentando o fator de concentração de tensão [40][52][56]. Pela análise, este fator não contribuiu para a queda da vida em fadiga do eixo soldado na velocidade de $15 \mathrm{~mm} / \mathrm{seg}$, embora este fator possa ter promovido o aumento da incidência de mordeduras na margem da solda.

O resultado das análises e a curva de vida sugerem que os defeitos apontados contribuíram para a redução da vida em fadiga do eixo, embora estes defeitos sejam somente uma parte dos fatores que conduzem à falha de juntas soldadas. A vida em fadiga destas juntas depende também das 
características dos materiais utilizados, da geometria do eixo, das condições de carregamento, de tensões residuais entre outros, que entretanto podem ser considerados iguais para as duas classes de eixos aqui estudados.

Como proposta para estudo posterior recomenda-se uma análise de regressão dos parâmetros de soldagem, a fim de conseguir parâmetros adequados para alteração do perfil de cordões de solda, sem detrimento de suas características mecânicas. 


\section{REFERÊNCIAS BIBLIOGRÁFICAS}

[1] Heissing; B., Ersoy, M., Fahrwerkhandbuch - Grundlagen, Fahrdynamik, Komponenten, Systeme, Mechatronik, Perspektiven, 1.Auflage, Vieweg \& Sohn Verlag, Wiesbaden, 2007.

[2] Reimpell; J., Betzler; J., Fahrwerktechnik: Grundlagen, Vogel Fachbuch, 4 ${ }^{\mathrm{a}}$ Auflage, Würzburg, 2000, p.37-42.

[3] Gescheidle; R., Tabellenbuch Kraftfahrzeugtechnik, Europa Lehrmittel, 14ª Auflage, Haan-Gruiten, 2003.

[4] Hertzberg; R. W., Deformation and Fracture Mechanics of Engineering Materials, $4^{\mathrm{a}}$ edition, New York: John Wiley \& Sons Inc., 1995.

[5] Schijve; J., Fatigue of structures and materials in the 20th century and the state of the art, Delft University of Technology, Faculty of Aerospace Engineering, International Journal of Fatigue 25, Netherlands, 2003, p. 679-702.

[6] Newman Jr.; J.C., The merging of fatigue and fracture mechanics concepts: a historical perspective, Mechanics of Materials Branch, NASA Langley Research Center, Progress in Aerospace Sciences 34, Hampton, Virginia, USA, 1998, p.347-390.

[7] Schütz; W., A History of Fatigue, Engineering Fracture Mechanics, IABG, D-85521 Ottobrunn, Germany, 1996, Vol. 54, No. 2, p.263-30

[8] Liu; J., Lifetime prediction under multiaxial variable amplitude loading - Further development of the shear stress intensity hypotheis, $7^{\mathrm{a}}$ International Conference on Biaxial/Multiaxial Fatigue and Fracture, Berlin, Germany, 2004.

[9] Nolting; A. E., DuQuesnay; D. L., The effect of mean stress and mean strain on fatigue damage following overloads, SAE International, no 2003-01-0910, 2003.

[10] Wainer; E, Soldagem, Associação Brasileira de Metais, 14 $14^{\mathrm{a}}$ edição ampliada, São Paulo, 1979, p.3. 
[11] Messler, R.W., Principles of Welding, Wiley-Interscience, EUA, 1999.

[12] Wainer; E, Brandi; S D, De Mello; F D H Soldagem: processos e metalurgia, Editora Edgard Blücher, São Paulo, 1992.

[13] Dong; P, Potukutchi; R, Agrawal; H, Perumalswani; P, Fatigue Analisys of Steel MIG Welds in Aumotove Structures, SAE1037627, 2004, p.31-39.

[14] Wu; W., MS Thesis. Department of Mechanical Engineering, University of New South Wales, Australia, 2002.

[15] Fortes, C., Soldagem MIG / MAG - traduzido e adaptado, ESAB, Agosto, 2004.

[16] Modenesi; P., Introdução à física do arco elétrico, UFMG, Belo Horizonte, Janeiro, 2005.

[17] Stembacka; N., Persson; K.A., Shielding gases for gas metal arc welding, Welding Journal - AWS, November, 1989. p.41-47.

[18] Marinho; L.C.D., da Silva; S.S., Paranhos; R., Análise da influência das variáveis do processo de soldagem MIG/MAG robotizado na geometria do cordão de solda com auxílio de planejamento de experimentos, Simpósio Brasileiro de Pesquisa Operacional, Campos do Jordão, 2001

[19] Kim; I.S. et al., A study on relationship between process variables and bead penetration for robotic CO2 arc welding, J. Mater. Process Technol., 2003, p.136:139145.

[20] Chan; B. et al., Modelling gas metal arc weld geometry using artificial neural network technology, Can. Metall. Quart., 38(1), 1999, p.43-51.

[21] Lee; J.I., Um; K.W., A prediction of welding process parameters by prediction of back-bead geometry, J. Mater. Process. Technol., 108, 2000, p.106-113. 
[22] Kim; I.S. et al., An investigation into an intelligent system for predicting bead geometry in GMA welding process. J. Mater. Process. Technol.,159, p.113-118, 2005.

[23] Modenesi; P.J, Avelar; R.C., The influence of small variations of wire characteristics on gas metal arc welding process stability, J. Mater. Process. Technol., 86, 1999, p.226-232.

[24] Chandel; R.S., Mathematical modelling of gas metal arc weld features, In: Proceedings of the forth international conference on modelling of casting and welding processes, 17- 22, Palm Coast (FL), April, 1988, p.109-120.

[25] Y1ld1z; C., The effect of process parameters on penetration in gas metal arc welding processes, M.Sc. Thesis, Sakarya University, Sakarya, Turkey, 2004.

[26] Masubuchi; K., Analysis of Welded Structures, Residual Stress, Distortion and Their Consequence, International Series on Material Science and Technology, Vol. 33, Pergamon Press., 1980.

[27] Hideyuki; S., Akitake; M., Drawbead Restraining Force When the Sliding Direction of the Sheet is not Normal to the Drawbead Line, A Study on Drawbead Restraining Force in Sheet Metal Forming, Journal of the Japan Society for Technology of Plasticity, 39 (448), 1998, p.33-44.

[28] Jang; C. D., Lee; C. H., Prediction of Welding Deformation of Ship Hull Blocks, Proceedings of International Workshop on Frontier Technology in Ship and Ocean Engineering, 2003, p.41-49.

[29] Tsai; C. L., Park; S. C., Cheng; W. T., Welding Distortion of a Thin-Plate Panel Structure, Welding Research Supplement, May, 1999, p.156-165.

[30] Potente; H., Schneiders; J., Herrmann; K.P., Ferber; F., Linnenbrock; K., Investigations concerning the development of inherent stresses during welding by using the drilled-hole method as well as the finite element method, Welding in the World, 45 (1/2), 2001, p.9-17.

[31] Boellinghaus; T., Kannengiesser; T., Effect of filler material selection and shrinkage restraint on stress strain build up in component welds, 6th International Trends in Welding Research Conference Proceedings, ASM International, 2003, p.906-911. 
[32] Kannengieber; T., Bollinghaus; T., Florian; W., Herold; H., Effect of weld metal strength and welding conditions on reaction forces and stress distribution of restrained components, Welding in the world, 45 (1/2), 2001, p.18-26.

[33] Ravi; et al., Assessment of some factors influencing the fatigue life of strenght mismatched HSLA steel weldments, Material \& Design, 25, 2004, p.125-135.

[34] Kotousov; A., Jaffar; M.F.M., Collapse load for a crack in a plate with a mismatched welded joint, Engineering Failure Analysis, 13, 2006, p.1065-1075.

[35] Thaulow; C. et al., On the interralationship between fracture thoughness and material mismatch for cracks located at the fusion line of weldments, Engineering Fracture Mechanics, 64, 1999, p.367-382.

[36] Shi; Y., Sun; S., Geometry effect of welded joints on failure assessment curves, Intermational Journal Pres. Ves. \& Piping, 74, 1998, p.71-76.

[37] Weisman; C., Welding Handbook, Vol. 1 Fundamental of Welding, $7^{\circ}$ Edition, American Welding Society, Miami, Florida, 1976.

[38] Bucci; R. J., Effect of Residual Stress on Fatigue Crack Growth Rate Measurement, Fracture Mechanics, ASTM STP 743, 1981, p.28-47.

[39] Itoh; Y. Z., Suruga; S., Kashiwaya, Prediction of Fatigue Crack Growth Rate in Welding Residual Stress Field, Journal of Engineering Fracture Mechanics, Vol. 33, No3, 1989, p.397-377.

[40] Nguyen; T.N., Wahab; M.A., The effect of Residual Stresses and Weld geometry on the improvement of Fatigue life, Journal of Materials Processing Technology 48 , 1995, p.581-588.

[41] Nguyen; T.N., Wahab; M.A., The effect of undercut and Residual Stresses on fatigue behaviour of misaligned butt joints, Engng. Fract. Mech., Vol.55, 1996, p.453-469.

[42] Nguyen; T.N., Wahab; M.A., The effect of Weld geometry and Residual Stresses on the Fatigue of Welded joints under combined loading, Journal of Materials Processing Technology 77 , 1998, p.201-208. 
[43] Kosteas; D., Estimating Residual Stress and Their Effect in Welded Aluminum Components in Fatigue, Analytical and Experimental Methods for Residual Stress Effects in Fatigue, ASTM STP 1004, Philadelphia, 1998, p.122-130.

[44] Berkovis; D.W., Kelly; Di S., Consideration of the Effect of Residual Stresses on Fatigue Welded Aluminum Alloys Structures, Journal of Fatigue \& Fracture of Engineering Material and Structure, Vol. 21, 1998, p.159-170.

[45] Elber; W., Fatigue Crack Growth under Cyclic Tension, Engineering Fracture Mechanics, 2, 1970, p.37-45.

[46] Nordmark; G.E., Herbein; W.C., Dickerson; P.B., Effect of Weld Discontinuities on Fatigue of Aluminum Butt Joints, Journal of Welding, 66(6), 1987, p.162-173.

[47] Berge; S., On the effect of plate thickness in fatigue of welds. Engng Fract Mech 1985;21(2): p.423-435.

[48] Ferreira; J.A., Branco; C.M., Fatigue Analysis and Prediction in Filled Welded Joints in the Low Thickness Range, Journal of Fatigue \& Fracture of Engineering Materials and Structures, 1990, Vol. 13, No. 3, p.201-212.

[49] Bell R.; Vosikovsky; O., A Fatigue Life Prediction Model for Multiple Cracks in Welded Joints for Offshore Structures, OMAE, Vol. III-B, Material Engineering, ASME, 1992.

[50] Linda; R., Fatigue Crack Growth of Weldments. Fatigue Fracture Testing of Weldments, ASTM Publ. STP 1058, 1990, p.16-33.

[51] Donald; J. K., A Procedure for Standardizing Crack Closure Levels, Mechanics of Fatigue Crack Closure, ASTM STP 982, 1988, p.222-229.

[52] Murthy; R.D.S., Gandhi; P., Madhava; R.A.G., A Model for Fatigue Prediction of Offshore Welded Stiffened Steel Tubular Joints Using FM Approach, International Journal of Offshore and Polar Engineering, 4(3), 1994, p.241-247. 
[53] Finch; D.M., Burdekin; F.M., Effects of welding residual stresses on significance of defects in various types of welded joint-I, Engineering Fracture Mechanics, Vol. 41, $\mathrm{n}^{\circ}$ 5, 1992, p.721-735.

[54] Dong; P., Recent progress in analysis of welding residual stresses, Report 1-3, Welding Research Council, Bulletin 455, September, 2000.

[55] Sanders; W. W. Jr., Lawrence; F.V., Jr., Fatigue Behavior of Aluminum Alloy Weldments, Fatigue Testing of Weldments, ASTM STP 648, 1977.

[56] Tso, L.Teng.; Chin, P.Fung.; Peng, H.Chang., Effect of weld geometry and residual stresses on fatigue in butt-welded joints, International Journal of Pressure Vessels and Piping 79, 2002, p.467-482.

[57] Kainuma; S., Mori; T., A fatigue strength evaluation method for load-carrying fillet welded cruciform joints, International Journal of Fatigue 28, 2006, p.864-872.

[58] Sanders; W. W., Gannon; S.M., Fatigue Behavior of Aluminum 5083 Butt Welds, WRC Bulletin 199, Welding Research Council, New York, 1974.

[59] Karadeniz; E., Ozsarac; U., Yildiz; C., The effect of process parameters on penetration in gas metal arc welding processes, Materials and Design 28, 2007, p.649-656.

[60] ASTM E647 - 95a, Standard Test Method for Measurement of Fatigue Crack Growth Rates, Annual Book of ASTM Standards, Vol. 11.03, 1995. 